Marcos Abdo Arbex

\title{
Avaliação dos efeitos do material particulado proveniente da queima da plantação de cana- de-açúcar sobre a morbidade respiratória na população de Araraquara - SP
}

Tese apresentada à Faculdade de Medicina da Universidade de São Paulo para a obtenção do título de Doutor em Medicina

Área de Concentração: Patologia

Orientador: Prof. Dr. Paulo Hilário do Nascimento Saldiva

SÃO PAULO

2001 
A vida dá muitas voltas. A vida nem é da gente.

(João Guimarães Rosa) 


\section{DEDICO ESTE TRABALHO}

A meus pais (Michel e Alzira), pela luta e dedicação incansáveis, compartilho toda a felicidade que certamente estão sentindo nesse momento. ("in memorian").

À minha esposa (Cleonice) e aos meus filhos (Renata, Guilherme e Flávio) pela compreensão, paciência e dedicação durante o período em que se viram privados de nosso convívio. 


\section{AGRADECIMENTOS}

Ao Prof. Dr. Paulo Hilário Nascimento Saldiva por ter acreditado em uma idéia e a transformado nesta tese de doutorado. O cientista Paulo Hilário Nascimento Saldiva é admirado pela criatividade e capacidade de sempre escolher o melhor caminho a ser seguido no campo do aprimoramento cientifico, Mas, não é só. Existe o ser humano "Pepino" com a rara sensibilidade de também sempre escolher o melhor caminho no campo do relacionamento pessoal. Como acredito que uma pessoa leva consigo as marcas das lições diárias de outras tantas pessoas, felizes são os "eleitos" que tem o privilégio de acompanha-los. Ter sido um deles, certamente me fez melhor.

Ao Prof. Dr. Alfésio Luiz Ferreira Braga, co-orientador de fato e de direito, pela orientação segura, atenta, prestativa, gentil, bem-humorada, paciente, triste nas tardes de domingo e crítica quando necessária, na elaboração desta tese.

À Prof ${ }^{\mathrm{a}}$. Gleice Margarete de Souza Conceição, por ter me conduzido de uma forma inteligente, gradual e racional, ao obscuro mundo da estatística. Soma-se a isso o seu apurado senso crítico, que foi de grande importância para a realização deste estudo em todas a suas fases.

Ao Prof. Dr. Luiz Alberto Amador Pereira, por ter me transmitido ensinamentos básicos da ciência epidemiológica e pelo auxílio na elaboração da aula de qualificação.

A Prof ${ }^{\text {a. }}$ Dr ${ }^{\text {a. }}$ Vera Botta, por ter acreditado em um projeto ainda incipiente e nele investido. 
A Prof ${ }^{a}$ Edna Samira B. Gobatti, por ter colocado à nossa disposição a Seção de Apoio Técnico Químico do Instituto de Química da UNESP de Araraquara.

A Silvia Helena Santagnelli Benedicto, pelo carinho, competência e dedicação com que realizou diariamente o trabalho de análise da fuligem da cana nos laboratórios do Instituto de Química da UNESP de Araraquara.

À direção, corpo clínico e funcionários do Hospital Nestor Goulart Reis da Secretária da Saúde do Estado de São Paulo, pelo apoio à realização do trabalho em todas as suas fases, desde a troca diária dos "baldinhos" até as sugestões na elaboração do relatório final.

À diretoria da UNIMED de Araraquara, especialmente ao Dr. Bruno Piva, que propiciou o levantamento dos dados retrospectivos de morbidade respiratória.

À Prof ${ }^{\text {a. }}$ Dr ${ }^{\text {a. }}$ Christiane Pienna Soares, da Faculdade de Ciências Farmacêuticas da UNESP de Araraquara, por suas sugestões e cobranças rigorosas durante a realização do estudo.

Ao Prof. Dr. Arnaldo Alves Cardoso do Instituto de Química da UNESP de Araraquara, que elucidou, com paciência, muitas dúvidas nos meus conhecimentos de química.

Ao Dr. Almir Zancul, da CETESB de Araraquara, por ter colocado a nossa disposição a sua vasta experiência pessoal e todo o seu extenso acervo bibliográfico sobre queima de cana-de-açúcar.

Ao Dr. Anuar M. Lauar, DD. Secretário de Saúde de Araraquara, à

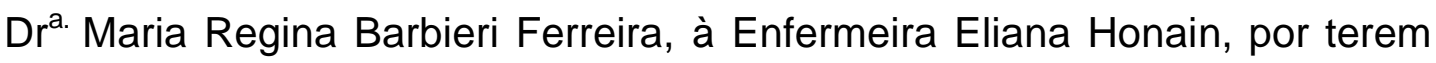
colocado a Secretaria Municipal da Saúde como parceira atuante na execução do estudo. 
Ao amigo Dr. Jorge Haddad, pela cobertura constante junto aos pacientes internados, sem a qual seria impossível a execução do estudo.

À Prof ${ }^{\mathrm{a}}$ Maria Helena Moura Neves pela correção ortográfica e gramatical do trabalho escrito.

À Marie, Isabel, Ivan, Rafael e ao Rafinha pela ajuda nos momentos de dificuldades (e não foram poucos) na utilização da informática.

À família Chiossi (Selma e Gastão), pelos múltiplos jantares em conjunto, pela revisão e correção do modelo final.

Aos componentes da banca de qualificação, $\operatorname{Prof}^{\mathrm{a}}{ }^{\mathrm{D}} \mathrm{Dr}^{\mathrm{a}}$. Vera Luiza Capellozi e Prof $^{\mathrm{a} .} \mathrm{Dr}^{\mathrm{a} .}$ Maria do Patrocínio Nunes Warth, pelas críticas e sugestões que possibilitaram tornar esse trabalho melhor.

Ao Prof. Dr. György Miklós Böhn, pela fidalguia com que me recebeu no Laboratório de Poluição Atmosférica Experimental (LPAE), e pela orientação segura quando se fazia necessário.

Aos amigos do LPAE, Eliana Tigre, Macchione, Débora, Miriam, Ana Júlia, Joya, Cristina, Lourdes, Simone, Chin e Paulo Afonso. Vocês tornaram caminho percorrido mais agradável. Esse trabalho, certamente, tem um pouco de cada um de vocês.

A Maria Eli Pereira de Castro, secretária da Chefia do Departamento de Patologia, pela sua dedicação, pela sua compreensão e pela sua eficiência.

A Liduvina, Vera e Lenira, da biblioteca do Departamento de Patologia, pelo apoio constante.

E a todos, que de forma direta ou indireta, contribuíram de alguma maneira para a execução do estudo. 


\section{SUMÁRIO}

\section{LISTA DE FIGURAS \\ LISTA DE TABELAS \\ RESUMO \\ SUMMARY}

1. INTRODUÇÃO …............................................................... 1

1.1. O homem e o fogo …………………………………........ 2

1.2. A combustão da biomassa....................................................... 4

1.3. Poluição do ar e saúde pública.................................................. 9

1.4. Queima da biomassa e repercussão sobre a saúde................ 18

1.4.1. Queima de biomassa em ambientes internos e agravo à saúde... 20

1.4.2. Queima de biomassa em ambientes abertos e agravos à saúde.. 22

1.4.3. Principais produtos emitidos pela queima da biomassa, suas características físico-químicas e seus efeitos sobre os seres vivos... 30

1.4.3.1. Material Particulado ............................................. 31

1.4.3.2. Hidrocarbonetos Policíclicos Aromáticos (HPAs).............. 39

1.4.3.3. Monóxido de Carbono................................................ 42

1.4.3.4. Aldeídos............................................................... 43

1.4.3.5. Ácidos Orgânicos.................................................... 44

1.4.3.6. Compostos Orgânicos Voláteis e Semivoláteis( COVs)..... 44

1.4.3.7. Compostos de Nitrogênio e Enxofre............................... 45

1.4.3.8. Ozônio.................................................................. 47

1.4.3.9. Outros Gases................................................... 47

1.4.3.10. Fração Inorgânica das Partículas ............................... 48 
1.5. A Cana-de-Açúcar......................................................... 49

1.5.1. Histórico da cana-de-açúcar .................................................. 49

1.5.2. A cana-de-açúcar no Brasil.................................................... 54

1.5.3. A cana-de-açúcar como fonte de energia................................... 57

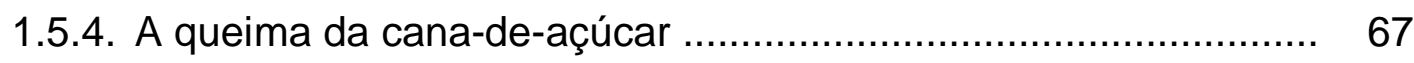

1.5.5. Produtos da gerados pela queima da cana-de-açúcar................ 71

1.5.6. Queima da cana-de-açúcar em Araraquara.............................. $\quad 77$

1.5.7. Repercussão da queima de cana-de-açúcar............................... 82

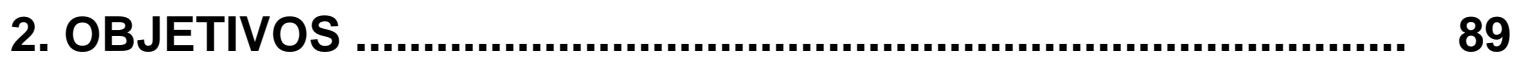

2.1. Geral.......................................................................... 90

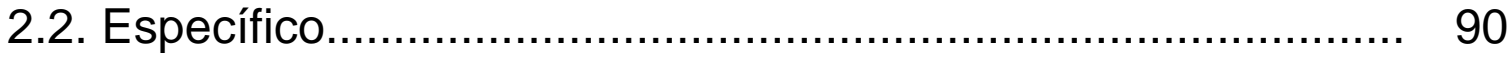

3. MATERIAL E MÉTODOS ….................................................. 91

3.1. Tipo de Estudo............................................................... 92

3.2. Localização de Araraquara no Estado de São Paulo.............. 93

3.3. Medidas do material particulado.......................................... 96

3.4. Medidas da morbidade respiratória..................................... 99

3.5. Dados meteorológicos....................................................... 101

3.6. Análise estatística........................................................... 102

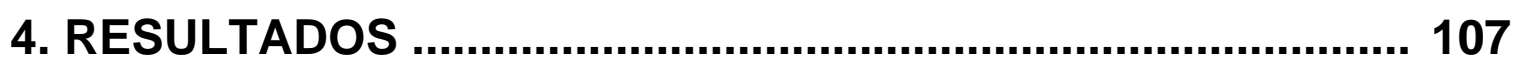

4.1. Análise descritiva das variáveis do estudo.......................... 108

4.1.1. Características da população estudada...................................... 108

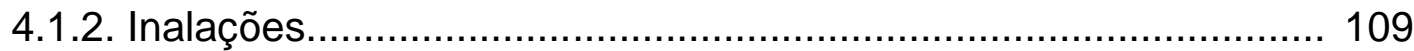

4.1.2.1. Análise descritiva do número de inalações..................... 109

4.1.2.2. Sazonalidade das inalações ao longo do período........... 110

4.2.1.3. Sazonalidade semanal do número de inalações.............. 111 
4.1.3. Peso do Sedimento.

4.1.3.1. Correlação linear do peso do sedimento........................ 112

4.1.3.2. Análise descritiva do peso do sedimento........................ 113

4.1.3.3. Sazonalidade do peso do sedimento ao longo do período 114

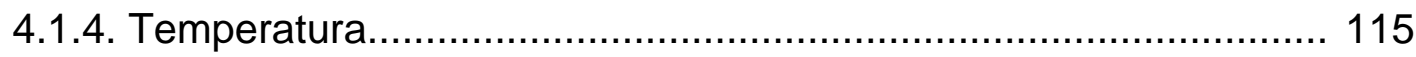

4.1.4.1. Análise descritiva da temperatura mínima diária.............. 115

4.1.4.2. Sazonalidade da temperatura mínima diária ao longo do período do estudo.

4.2. Análise Estatística.................................................................. 117

4.2.1. Correlação de Pearson............................................................. 117

4.2.2. Modelos de regressão de Poisson.............................................. 118

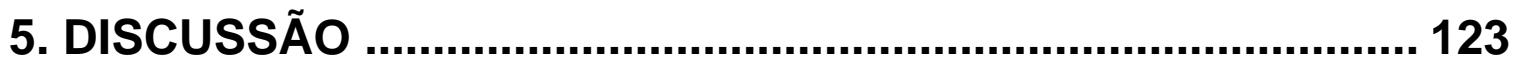

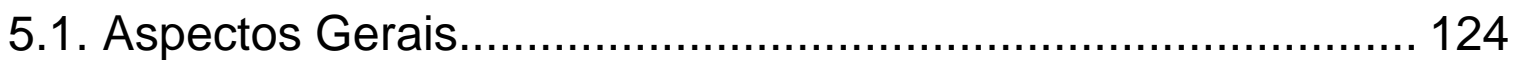

5.2. O Presente Estudo ............................................................. 127

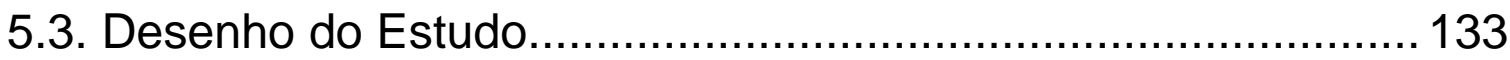

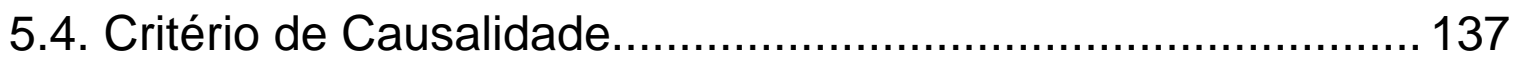

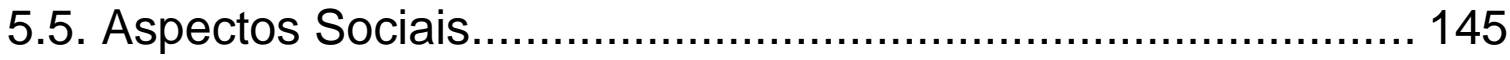

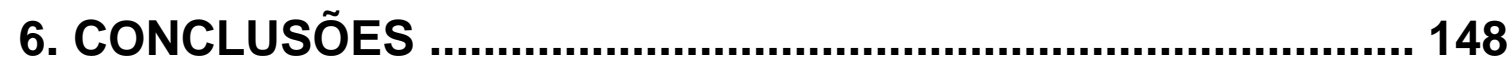

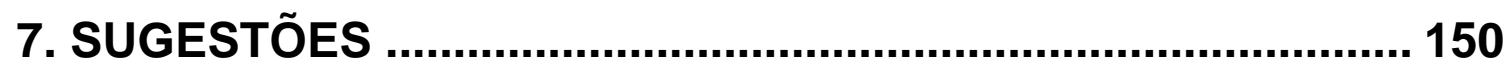

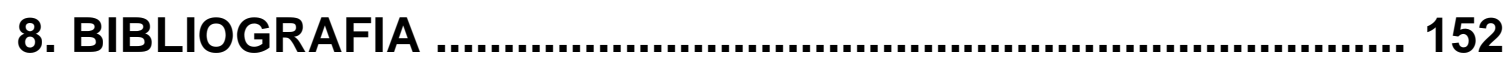





\section{LISTA DE FIGURAS}

Figura 1. A névoa sobre a Indonésia em 19/10/1997, causada pelos incêndios florestais

Figura 2. Esquema da distribuição de tamanho das partículas na atmosfera mostrando os três modos, as principais fontes e os principais processos envolvidos na remoção em cada modo

Figura 3. Mecanismos hipotéticos pelos quais a inalação de partículas pode levar a morte

Figura 4. Distribuição do número de partículas de acordo com o tamanho aerodinâmico no centro de Brisbaine, distante $20 \mathrm{~km}$ da queima de biomassa (vegetação rasteira) comparado a distribuição de partículas sem a influência da queima

Figura 5. Distribuição do número de partículas de acordo com o tamanho aerodinâmico no centro de Jabiru distante $200 \mathrm{~m}$ de queima de biomassa (grama), e a distribuição de partículas no mesmo local sem a influência da queima .....

Figura 6. Fórmulas estruturais dos HPAs considerados como poluentes prioritários pela USEPA

Figura 7. A origem e as migrações da cana-de-açúcar

Figura 8. Evolução das vendas de veículos a álcool no Brasil (1979-1999)

Figura 9. Área de cana-de-açúcar (milhares de hectares) cultivada no Brasil e no Estado de São Paulo 
Figura 10. Distribuição (\%) da produção de cana-de-açúcar nos estados brasileiros

Figura 11. Área de cultivo de cana-de-açúcar no Estado de São Paulo no ano de 1997.

Figura 12. Evolução da emissão de monóxido de carbono proveniente da queima de cana-de-açúcar no Brasil entre 1985-1996

Figura 13. Evolução da emissão de metano proveniente da queima de cana-de-açúcar no Brasil entre 1985-1996

Figura 14. Evolução da emissão de dióxido de nitrogênio proveniente da queima de cana-de-açúcar no Brasil entre 1985-1996

Figura 15. Evolução da emissão de óxido de nitrogênio proveniente da queima de cana-de-açúcar no Brasil entre 1985-1996... 75

Figura 16. Fuligem proveniente da queima da cana-de-açúcar retida em diferentes tamanhos de filtros do Impactador de Moudi...

Figura 17. Queima no canavial

Figura 18. Curvas das variações das temperaturas durante a queima da cana-de-açúcar

Figura 19. Fumaça e fuligem proveniente da queima da cana-deaçúcar

Figura 20. Proporcionalidade dos efeitos adversos à saúde atribuíveis a população em geral decorrente dos poluentes emitidos pela queima de vegetação

Figura 21 Localização de Araraquara no Estado de São Paulo ........ 94

Figura 22. Região canavieira de Araraquara ..................................... 95 
Figura 23 Produção da cana-de-açúcar (em toneladas) na região de Araraquara e no Estado de São Paulo (1993-2001) .......... 95

Figura 24. Mapa de Araraquara demonstrando os locais de amostragem

Figura 25. Vista panorâmica do recipiente plástico 97

Figura 26. Detalhe da fuligem depositada no recipiente plástico 98

Figura 27. Distribuição percentual entre usuários e não usuários do convênio médico Unimed na cidade de Araraquara no ano de 1995.

Figura 28. Variação diária no número de inalações no período do 110 estudo

Figura 29. Número médio de inalações de acordo com os dias da semana no serviço de emergência do Hospital São Paulo, durante o período do estudo

Figura 30. Correlação entre as médias do peso do sedimento (mg) medidas na área central e na área rural da cidade de Araraquara

Figura 31. Variação diária do peso do sedimento no período do 114 estudo

Figura 32. Variação diária da temperatura mínima durante o período de estudo

Figura 33. Curva de alisamento do número de inalações em função do número de dias transcorridos

Figura 34. Risco relativo e intervalo de confiança de 95\% para inalações com concentrações crescentes do sedimento (média móvel de dois dias) 


\section{LISTA DE TABELAS}

Tabela 1. Principais produtos emitidos nos diferentes estágios da combustão de biomassa

Tabela 2. Comparativo das estimativas de emissão de gases e partículas em nível mundial

Tabela 3. Padrões de qualidade do ar para os principais poluentes estabelecidos pela "USEPA"

Tabela 4. Padrões nacionais da qualidade do ar - resolução do CONAMA de 28/06/1990

Tabela 5. Área total cultivada (milhares de hectares) com cana-deaçúcar no Brasil (BR), nas Regiões Norte-Nordeste (NN), Centro-Sul (CS) e Estado de São Paulo (SP)

Tabela 6. Área total colhida (milhares de hectares) com cana-deaçúcar no Brasil (BR), nas Regiões Norte-Nordeste (NN), Centro-Sul (CS) e Estado de São Paulo (SP).

Tabela 7. Álcool total (anidro-hidratado) por safra (milhares de $\mathrm{m}^{3}$ ) no Brasil (BR), nas Regiões Norte-Nordeste (NN), CentroSul (CS), e Estado de São Paulo (SP)

Tabela 8. Álcool total (na forma de anidro) por safra (milhares de $\mathrm{m}^{3}$ ) no Brasil (BR), nas Regiões Norte-Nordeste (NN), Centro-Sul (CS), e Estado de São Paulo (SP)

Tabela 9. Dados coletados em Araraquara com amostrador de grandes volumes para poeira total em suspensão $(1985 / 1986)$ 
Tabela 10. Método de medição dos poluentes em Araraquara nos anos 1997/1998

Tabela 11. Avaliação da qualidade do ar e quantificação dos poluentes em Araraquara nos anos 1997/1998

Tabela 12. Comparação entre a quantidade de material carbonáceo em Araraquara e em duas estações medidoras da região metropolitana de São Paulo

Tabela 13. Coloração dos filtros do Impactador de Moudi após a coleta da "fuligem da cana" durante 48 horas

Tabela 14. Analise descritiva do número de inalações no período do estudo

Tabela 15. Analise descritiva do peso do sedimento no período do 113 estudo

Tabela 16. Analise descritiva da temperatura mínima diária no período do estudo

Tabela 17. Coeficiente de correlação de Pearson para as principais variáveis do estudo

Tabela 18. Coeficientes de regressão e intervalos de confiança de 95\% para o peso do sedimento (níveis diários e médias moveis) em modelos controlados para sazonalidade, fim de semana e temperatura mínima

Tabela 19. Coeficientes e intervalos de confiança de $95 \%$ para as variáveis no modelo final 


\section{RESUMO}

ARBEX, M.A. Avaliação dos efeitos do material particulado proveniente da queima da plantação de cana-de-açúcar sobre a morbidade respiratória na população de Araraquara-SP. São Paulo, 2001. 188p. Tese (Doutorado) - Faculdade de Medicina da Universidade de São Paulo.

Esse estudo epidemiológico de séries temporais avalia a associação entre o material particulado coletado durante a queima de plantações de cana-deaçúcar e um indicador de morbidade respiratória em Araraquara (SP). Entre 26 de maio e 31 de agosto de 1995, o número diário de pacientes que necessitaram inalações em um dos principais hospitais da cidade foi quantificado e utilizado para estimar a morbidade respiratória. Para estimar o nível da poluição do ar foi quantificado diariamente o peso do sedimento do material particulado proveniente da fuligem da cana-de-açúcar, obtido por sedimentação simples, coletado em dois pontos da cidade, um localizado no centro e o segundo na zona rural. A associação entre o peso do sedimento e o número de pacientes que necessitaram de terapia inalatória, foi avaliada pelo modelo aditivo generalizado da regressão de Poisson com controle para sazonalidade, temperatura e dias da semana. Encontrou-se uma associação positiva significante e dose-dependente entre o número de terapia inalatória e o peso do sedimento. Um aumento de $10 \mathrm{mg}$ no peso do sedimento está associado a um risco relativo de terapêutica inalatória de 1,09 (1-1,19). Nos dias mais poluídos o risco relativo de terapêutica inalatória é de $1,20(1,03-$ 1,39 ). Esses resultados indicam que a queima das plantações da cana-deaçúcar pode causar efeitos deletérios à saúde da população exposta. 


\section{SUMMARY}

ARBEX, M.A. Evaluation of the effects of particulate matter deriving from sugar cane plantation burning on the respiratory morbidity of the Araraquara City population. São Paulo, 2001. 188p. - Faculdade de Medicina da Universidade de São Paulo.

This times series epidemiological study was designed to evaluate the association between particulate matter collected during sugar cane plantation burning and an indicator of morbidity respiratory in Araraquara, São Paulo State, Brazil. From May $26^{\text {th }}$ to August $31^{\text {st }}, 1995$, the daily number of patients that received inhalation therapy in one of the main hospitals of the city was recorded and used as a morbidity respiratory estimation. In order to estimate air pollution levels the daily sediment weight from sugar cane particulate matter was measured after collected by simple sedimentation process, in two strategic points of the city: one in the central area and the other in the rural area. The association between the sediment weight and the number of patients who received inhalation therapy was evaluated by means of generalized additive Poisson regression models controlled for seasonality, temperature and days of the week. A positive, significant and dosedependent relationship was found between the number of inhalation therapy and the sediment weight. The relative risk of inhalation therapy associated with an increase of $10 \mathrm{mg}$ in the sediment weight was $1.09(1-1.19)$. On the most polluted days the relative risk for inhalation therapy was 1.20 (1.03 1.39). These results indicate that sugar cane plantations burning may cause deleterious health effects in the exposed population. 


\section{INTRODUCÃO}




\subsection{O Homem e o Fogo}

A queima da vegetação ocasionada por fatores climáticos e ambientais, ocorre há cerca de 400 milhões de anos, e contribui para desastres ecológicos, por vezes de grandes proporções. A fuligem, produzida por extensa queima de vegetação, com elevadas concentrações de carbono elementar, é a causa mais provável do fim da era dos grandes répteis, há 65 milhões de anos atrás, no limite entre o Período Cretáceo e o Período Terciário (ANDREAE, 1991).

A partir da descoberta do fogo o homem passou a contribuir de forma atuante, porém não consciente, para a deterioração da qualidade do meio ambiente e a sofrer as conseqüências desse ato (UTELL et al., 1988). A queima de biomassa (qualquer material derivado de plantas ou animal) produzida pelos seres humanos foi talvez o primeiro indicio de poluição do ar em ambientes fechados, quando, em tempos pré-históricos, o homem procurou climas temperados e, quando necessário, construiu abrigos e usou o fogo para cozinhar, aquecer e iluminar. O fogo produzia altos níveis de poluição do ar, o que ficou evidenciado pela fuligem encontrada em cavernas pré-históricas. Fuligens encontradas em cavernas no sul da África 
indicam que a raça humana utilizava o fogo desde 1,5 milhões de anos (BRUCE et al., 2000; WHO, 2000b).

A mão do homem levou o fogo a sair das cavernas e alastrar-se pela vegetação no exato momento em que, para sua sobrevivência, o homem passou a cultivar plantas e criar animais, e, dessa forma a raça humana passou a interferir na natureza, modificando, no tempo e no espaço, a ordem natural do meio ambiente. Essa interferência passou a ser cada vez maior em tempos mais recentes, devido à crescente explosão demográfica após o advento da revolução indústrial. Ainda nos dias de hoje a prática da queima de biomassa pelo homem é rotina para queima de resíduos agrícolas e de esterco de animais, remoção de vegetação seca (principalmente no cerrado), produção de energia para aquecimento e preparo de alimentos, produção de carvão para fins indústriais e domésticos (CRUTZEN; CARMICHAEL, 1993).

A incineração de biomassa é a maior fonte doméstica de energia nos países em desenvolvimento. Aproximadamente metade da população do planeta e mais de noventa por cento de casas na região rural dos países em desenvolvimento permanecem utilizando energia proveniente da queima de biomassa, o que produz altos índices de poluição do ar em ambientes fechados, afetando particularmente a saúde das mulheres que cozinham e as crianças, as quais ficam sujeitas, a um aumento de risco de infecção 
respiratória, o maior assassino de crianças em países em desenvolvimento (BRUCE et al., 2000; WHO, 2000b).

A queima natural ou acidental de vegetação, apesar do grande avanço tecnológico experimentado pela humanidade, ou até justamente por causa dele, torna-se por vezes incontrolada, atingindo grandes extensões de florestas, grandes extensões de savanas, ou outras vegetações menos densas. O fogo é um problema crescente no que resta das florestas tropicais do planeta. No entanto, apesar dos anos de estudos cientifico e da atenção da mídia em relação ao desmatamento e às queimadas, a incidência e o efeito dos incêndios acidentais nas florestas têm sido ignorado. As grandes queimadas em Bornéu (1983 e 1997), Tailândia (1997), Indonésia (1997), Roraima (1997-1998), Mato Grosso (1998) e Pará (1998), despertaram a atenção para o problema, mas medidas tomadas para prevenir ou controlar tais incêndios ainda são insuficientes (COCHRANE, 2000).

\subsection{A Combustão da Biomassa}

A combustão é um processo químico pelo qual um material reage rapidamente com o oxigênio do ar, produzindo luz e calor intenso.

A combustão pode ser completa ou incompleta. A combustão do material é completa ou perfeita quando o hidrogênio e carbono do material são totalmente oxidados a dióxido de carbono e água. Isto acontece somente 
sob condições ideais. O fogo produz uma combustão incompleta devido a um insuficiente suprimento de oxigênio. Como resultado, há a produção de outros produtos como compostos não oxidados totalmente (monóxido de carbono, por exemplo) ou compostos reduzidos (metano, hidrocarbonetos não metanos, amônia, por exemplo) (DELMAS et al., 1995). Os compostos derivados da combustão são encontrados na fumaça, a qual freqüentemente consiste em partículas respiráveis e gases. A fumaça é por si só uma mistura complexa com componentes que dependem do tipo de combustão, do conteúdo da mistura, da quantidade de biomassa queimada, dos aditivos existentes no material como, por exemplo, os pesticidas e da temperatura da combustão (BREYSSE, 1984).

Os produtos emitidos durante a queima da biomassa dependem da eficiência da combustão, que é definida como a proporção de carbono emitido durante a queima como dióxido de carbono. Por conveniência, a eficiência da combustão pode ser definida como a proporção do carbono liberado como dióxido de carbono, dividido pela soma do dióxido de carbono e do monóxido de carbono liberado. Alternativamente dividindo-se a quantidade de monóxido de carbono liberado pela quantidade de dióxido de carbono liberado obtém-se uma medida aproximada da eficiência da combustão (WARD; HARDY, 1991; WHO, 1999).

A quantidade de biomassa consumida, a composição da fumaça e a proporção dos produtos emitidos dependem da eficiência da combustão e essa 
por sua vez depende das características físicas e químicas do ecossistema associadas com fatores do meio ambiente (umidade, temperatura, velocidade e direção dos ventos) e do tipo de ignição (WARD et al., 1992).

A queima de biomassa se processa em três estágios: ignition (ignição), flaming (combustão com chama), smoldering (combustão com ausência de chama). A ignição é o processo inicial no qual se tem pequena chama. No segundo estágio (flaming) a combustão é mais eficiente e há emissão de $\mathrm{CO}_{2}, \mathrm{H}_{2} \mathrm{O}, \mathrm{N}_{2}, \mathrm{NO}_{x}$ e $\mathrm{SO}_{2}$. No terceiro estágio (smoldering), processo de baixa temperatura e ausência de chama, há emissão de grandes quantidades de compostos oxidados incompletamente (por exemplo, $\mathrm{CO}, \mathrm{CH}_{4}$, e outros hidrocarbonetos). Tais processos envolvem diferentes reações químicas e como conseqüência produzem diferentes produtos. A característica da biomassa (disposição, tamanho, distribuição, mistura, composição química) afeta a duração de cada fase da combustão. Na queima de savanas, por exemplo, noventa por cento da vegetação pode ser consumida na combustão com chamas, enquanto na combustão de toras apodrecidas, carvão, palha e turfa, noventa por cento da biomassa é consumida, durante a combustão com ausência de chamas. Os produtos emitidos durante a combustão de biomassa dependem da proporção flamering/smoldering (WARD et al., 1992; CRUTZEN; CARMICHAEL, 1993). 
Os principais produtos emitidos durante os diferentes estágios da combustão da biomassa são apresentados na tabela 1 (LOBERT; WARNATZ, 1993).

Tabela 1. Principais produtos emitidos nos diferentes estágios da combustão de biomassa (LOBERT; WARNATZ, 1993).

\begin{tabular}{|c|c|c|}
\hline ESTÁGIO “FLAMING” & INTERMEDIÁRIO & ESTÁGIO “SMOLDERING” \\
\hline $\begin{array}{l}\text { - Dióxido de carbono }\left(\mathrm{CO}_{2}\right) \\
\text { - Óxido nítrico ( } \mathrm{NO}) \\
\text { - Dióxido de enxofre }(\mathrm{SO} 2) \\
\text { - Óxido nitroso }\left(\mathrm{N}_{2} \mathrm{O}\right) \\
\text { - Nitrogênio }\left(\mathrm{N}_{2}\right) \\
\text { - Partículas com alta \% de } \\
\text { carbono elementar }\end{array}$ & $\begin{array}{l}\text { - Etino }\left(\mathrm{C}_{2} \mathrm{H}_{2}\right) \\
\text { - Cianogênio (NCCN) }\end{array}$ & $\begin{array}{l}\text { - Monóxido de carbono }(\mathrm{CO}) \\
\text { - } \text { Metano }\left(\mathrm{CH}_{4}\right) \\
\text { - } \text { Hidrocarbonetos (HC, HPA) } \\
\text { - Amônia }\left(\mathrm{NH}_{3}\right) \\
\text { - Cianeto de hidrogênio }(\mathrm{HCN}) \\
\text { - Cianeto de metila }\left(\mathrm{CH}_{3} \mathrm{CN}\right) \\
\text { - Aminas, heterocíclicos, } \\
\text { - } \text { aminoácidos } \\
\text { - Cloreto de metila }\left(\mathrm{CH}_{3} \mathrm{Cl}\right) \\
\left.\text { - } \text { ( } \mathrm{H}_{2} \mathrm{~S}, \mathrm{COS}, \mathrm{DMS}, \mathrm{DMDS}\right) \text {. } \\
\text { carbulas com baixa \% de }\end{array}$ \\
\hline
\end{tabular}

Os produtos emitidos sofrem diversas transformações fotoquímicas, e em conseqüência dessas transformações a névoa proveniente da queima de biomassa pode apresentar diversas substâncias como, por exemplo, ozônio, peróxidos, aldeídos e ácidos orgânicos. 
A tabela 2 compara as estimativas de emissão de gases e partículas emitidas pela queima de biomassa em relação à soma de todas as outras fontes de emissão (CRUTZEN; ANDREAE, 1990).

Tabela 2. Comparativo das estimativas de emissão de gases e partículas em nível mundial (CRUTZEN; ANDREAE, 1990).

\begin{tabular}{|c|c|c|}
\hline ESPÉCIES & $\begin{array}{c}\text { EMISSÕES DA QUEIMA } \\
\text { DE BIOMASSA }\end{array}$ & $\begin{array}{l}\text { EMISSÕES MUNDIAIS } \\
\text { (todas as fontes) }\end{array}$ \\
\hline $\mathrm{CO}$ & $120-510 \mathrm{Tg}$ C/ano & 600-1300 Tg C/ano \\
\hline $\mathrm{CH}_{4}$ & 11-53 Tg C/ano & 400-600 Tg C/ano \\
\hline $\mathrm{H}_{2}$ & 5-16 Tg/ano & 36 Tg/ano \\
\hline $\mathrm{CH}_{3} \mathrm{Cl}$ & 0,5-2 Tg/ano & 2 Tg N/ano \\
\hline NO & $2,1-5,5 \mathrm{Tg}$ N/ano & 25-60 Tg N/ano \\
\hline $\mathrm{HCN}, \mathrm{CH}_{3} \mathrm{CN}$ & 0,5-1,7 Tg N/ano & $>0,4 \mathrm{Tg}$ N/ano \\
\hline cos & 0,04-0,20 Tg S/ano & 0,6-1,5 Tg S/ano \\
\hline $\begin{array}{l}\text { Carbono orgânico } \\
\text { particulado }\end{array}$ & 24-102 Tg/ano & 180 Tg/ano \\
\hline Carbono elementar & 6,4-28 Tg/ano & 20-30 Tg/ano \\
\hline
\end{tabular}

A combustão de biomassa, cujo maior percentual, cerca de oitenta por cento, ocorre nos trópicos, é a maior fonte de produção de gases tóxicos, material particulado e gases do efeito estufa através do planeta. A exposição dos seres vivos a esses poluentes pode produzir a curto e em longo prazo efeitos deletérios à saúde humana (CRUTZEN; ANDREAE, 1990; LOBERT, 1990). 


\subsection{Poluição do Ar e Saúde Pública}

A população das cidades da antiguidade usava madeira como fonte de energia. A partir do século treze com a depleção de florestas circunvizinhas, Londres tornou-se a primeira cidade a utilizar grandes quantidades de carvão. Em 1257, Eleanor de Provence, esposa de Henrique III, reclamava da grande quantidade de fumaça do carvão existente no Castelo de Nottingham. O rei Eduardo I (1272-1307), estabeleceu leis rígidas contra o uso indiscriminado da queima de carvão, que produzia segundo ele, um céu de fumaça. O parlamento inglês liberou a tortura e a forca para todo o individuo que vendesse ou queimasse carvão, à margem das leis.

O uso do carvão como fonte de energia foi o maior fator para a Revolução Indústrial, a qual formou a base da nossa atual sociedade tecnológica. Infelizmente, em associação intima com os benefícios auferidos em conseqüência dos enormes avanços da nossa sociedade tecnológica, convivemos com uma proporcional degradação do meio ambiente (WARK et al., 1998; BLIMBESCOMBE, 1999).

Apesar da percepção e de leis sobre a poluição do ar datarem do século treze, somente em anos recentes (considerando a história da humanidade), o problema passou a ser documentado. 
Em 1873, em Londres, durante um episodio de névoa (fog), houve 268 mortes inesperadas por patologia respiratória (WARK et al., 1998)

Em 1930, no Vale de Meuse, uma região da Bélgica, localizada entre as cidades de Huy e Liége, onde havia uma grande concentração de indústrias, cerca de 26, distribuídas em uma área de cerca de 20 quilômetros quadrados e que utilizavam preferencialmente fornos de carvão e gasogênio. Durante os cinco primeiros dias de dezembro, sob condições climáticas desfavoráveis para a dispersão dos poluentes atmosféricos, foi documentado um aumento no número de doenças respiratórias e sessenta mortes, dez vezes mais que a média histórica (Firket, 1931).

Em janeiro de 1931, em Manchester, Inglaterra durante 9 dias de espessa névoa e condições climáticas desfavoráveis, 592 pessoas morreram, o que representou um grande aumento em relação à média histórica (WARK et al., 1998).

Em 1948, em Donora, Pensilvânia, EUA, uma pequena cidade de quatorze mil habitantes, dominada por siderúrgicas e fábricas de produtos químicos ocorreu um episódio de inversão térmica que impediu a dispersão dos poluentes formando uma névoa densa que cobriu a cidade por 6 dias. Durante esse período estudos mostraram que aproximadamente metade da população apresentou sintomas de doenças cardiorrespiratórias e 20 pessoas morreram. Dez anos após o incidente, os indivíduos residentes em 
Donora que apresentaram patologia aguda durante o episódio mostraram ter uma taxa de morbidade maior que a média da população em geral. Estatísticas também demonstraram que esses indivíduos tiveram uma taxa de morte precoce superior à média geral da população (SHERENK et al., 1949; WARK et al., 1998).

Em dezembro de 1952, em Londres, ocorreu o mais clássico e grave episódio dos efeitos deletérios da poluição do ar. Entre cinco e nove de dezembro, uma grande onda de frio, levou a população a utilizar uma grande quantidade de carvão e esse fato associado a uma inversão térmica que impediu a dispersão dos poluentes, produziu uma densa névoa, composta principalmente por material particulado e enxofre. A névoa permaneceu estacionada na cidade, próxima ao solo, por três dias, ocasionando um aumento de quatro mil mortes em relação à média de óbitos em períodos semelhantes. O sistema hospitalar londrino, considerado um dos mais eficientes do planeta, entrou em colapso. As estatísticas indicaram que a grande maioria dos indivíduos que morreram apresentava história prévia de bronquite crônica, enfisema, ou patologia cardiovascular (LOGAN, 1953).

Esses episódios agudos apesar de dramáticos, chamaram a atenção da população, dos pesquisadores, e das autoridades no sentido de estabelecer medidas de proteção à população em relação à poluição do ar. 
A partir da década de cinqüenta, nos Estados Unidos e na Europa, uma série de medidas foram adotadas com o objetivo de se identificarem os poluentes mais comumente encontrados, e regulamentar, padrões de qualidade do ar com o intuito de se evitarem agravos à saúde publica.

Em 1970, a agência responsável pela proteção ambiental nos Estados Unidos da América ("U.S. Environmental Protection Agency "USEPA") veio a estabelecer quais eram os principais poluentes, ou seja, aqueles que poderiam causar danos a saúde publica e ao bem estar das pessoas. Foram identificados como principais poluentes atmosféricos: o ozônio $\left(\mathrm{O}_{3}\right)$, o dióxido de nitrogênio $\left(\mathrm{NO}_{2}\right)$, o dióxido de enxofre $\left(\mathrm{SO}_{2}\right)$, o monóxido de carbono (CO) e o material particulado inalável (partículas com diâmetro menor ou igual a $10 \mu \mathrm{m}$ ) partículas essas que podem atingir as vias aérea inferiores ( BASCON et al., 1996). Em junho de 1997 estipulou-se um novo padrão para partículas inaláveis, o $\mathrm{PM}_{2,5}$, que pode penetrar mais profundamente no trato respiratório. Estudos mostram que a relação entre $\mathrm{PM}_{2,5}$ e $\mathrm{PM}_{10}$ varia entre 0,35 e 0,60 (OSTRO; CHESNUT, 1998)

Apesar de esses serem os poluentes mais comuns dentro dos centros urbanos, eles não são os únicos, merecendo citação ainda, os hidrocarbonetos, aldeídos e metais pesados (BASCOM et al., 1996). Seus respectivos padrões (padrão de qualidade do ar ambiente- ("National Ambient Air Quality Standards - NAAQS"), foram definidos, após criterioso levantamento de todas a evidências relevantes, dentro de uma margem de 
segurança estabelecido pela "USEPA". Esses padrões deveriam ser aqueles necessários para proteger a saúde não apenas dos grupos mais susceptíveis, ou seja, os portadores de doenças respiratórias prévias, mas também a população em geral (Tabela 3).

Tabela 3. Padrões de qualidade do ar para os principais poluentes estabelecidos pela "USEPA" (BASCON et al., 1996).

\begin{tabular}{|c|c|c|}
\hline Poluentes & Padrões Primários & Tempo Médio \\
\hline $\mathrm{O}_{3}$ & $235 \mu \mathrm{g} / \mathrm{m}^{3}$ & Média máxima diária de 1 hora \\
$\mathrm{SO}_{2}$ & $80 \mu \mathrm{g} / \mathrm{m}^{3}$ & Média aritmética anual \\
& $365 \mu \mathrm{g} / \mathrm{m}^{3}$ & Nível Máximo em 24 horas \\
$\mathrm{NO}_{2}$ & $100 \mu \mathrm{g} / \mathrm{m}^{3}$ & Média aritmética anual \\
$\mathrm{CO}$ & $10 \mu \mathrm{g} / \mathrm{m}^{3}$ & Média máxima de 8 horas \\
& $40 \mu \mathrm{g} / \mathrm{m}^{3}$ & Nível máximo em 1 hora \\
$\mathrm{PM}_{10}$ & $50 \mu \mathrm{g} / \mathrm{m}^{3}$ & Média aritmética anual \\
& $150 \mu \mathrm{g} / \mathrm{m}^{3}$ & Nível limite para 24 horas \\
$\mathrm{PM}_{2,5}$ & $15 \mu \mathrm{g} / \mathrm{m}^{3}$ & Média Aritmética Anual \\
& $65 \mu \mathrm{g} / \mathrm{m}^{3}$ & Nível limite para 24 horas \\
\hline
\end{tabular}

Até 1987 a medida de referência padrão para material particulado era o "Total Suspended Particulate" ("TSP") que continha partículas até 100 $\mu \mathrm{m}$. Vários estudos epidemiológicos, que avaliavam a relação entre material particulado e saúde, realizados na década de 60/70, utilizaram "TSP" como indicador. A relação entre "TSP" e PM $_{10}$ é por volta de 0,5 a 0,6 (OSTRO, 1993). 
A Fumaça Britânica (Bristish Smoke -BS) é também um padrão de material particulado, utilizado em estudos na Grã Bretanha e em outros países europeus. Sua medida se faz através da medida das partículas escuras coletadas em filtros e da determinação da sua reflexão. As partículas escuras tendem a ser mais finas. A fumaça britânica é considerada como uma medida de concentração de partículas menores comparáveis ao $\mathrm{PM}_{10}$ (DOCKERY; POPE, 1994).

No Brasil, o Governo do Estado de São Paulo, em 1976, através do Decreto Estadual $n^{\circ} 8468$, regulamentou alguns padrões para a qualidade do ar. Em 28/06/1990, estes padrões foram ampliados em âmbito nacional e transformados em resolução pelo Conselho Nacional do Meio Ambiente (CONAMA).

Essa resolução estabelece dois tipos de padrões de qualidade de ar:

- Padrões primários de qualidade de ar: as concentrações que quando ultrapassadas, poderão afetar a saúde da população exposta (pode-se entender como padrões máximos toleráveis).

- Padrões secundários de qualidade de ar: as concentrações de poluentes atmosféricos abaixo dos quais se prevê o mínimo efeito adverso sobre o bem-estar da população, bem como o mínimo dano à fauna, à flora e ao meio ambiente em geral. 
Define, outrossim, que a curto e médio prazo, os padrões primários devem ser os desejados, e que, em longo prazo, os padrões secundários devem ser objetivados.

A mesma resolução do CONAMA regulamentou os níveis dos seguintes poluentes: partículas totais em suspensão (partículas com menos de $100 \mu \mathrm{m})$, dióxido de enxofre, monóxido de carbono, ozônio, fumaça(fuligem), partículas inaláveis, e dióxido de enxofre. Os padrões primários e secundários de qualidade do ar utilizados em âmbito nacional e no Estado de São Paulo são vistos na tabela 4 (COMPANHIA DE TECNOLOGIA DE SANEAMENTO AMBIENTAL - CETESB, 1997a).

Tabela 4. Padrões nacionais da qualidade do ar - resolução do CONAMA de 28/06/90 (CETESB, 1997a).

\begin{tabular}{|l|c|c|c|}
\hline Poluentes & $\begin{array}{c}\text { Padrão primário } \\
\left(\mu \mathbf{g} / \mathbf{m}^{\mathbf{3}}\right)\end{array}$ & $\begin{array}{c}\text { Padrão secundário } \\
\left(\mu \mathbf{g} / \mathbf{m}^{\mathbf{3}}\right)\end{array}$ & Amostragem \\
\hline O3 & 160 & 160 & 1 hora $^{(1)}$ \\
CO & $10.000(9 \mathrm{ppm})$ & $10.000(9 \mathrm{ppm})$ & horas $^{(1)}$ \\
SO2 & 80 & 40 & MAA $^{(2)}$ \\
Fumaça & 150 & 100 & 24 horas $^{(1)}$ \\
MAA $^{(2)}$ & $24 \mathrm{~h}^{(1)}$ \\
Partículas Totais & 240 & 150 & MGA $^{(3)}$ \\
(PTS="TSP") & 80 & 60 & 1 hora $^{(2)}$ \\
NO2 & 320 & 190 & MAA $^{(2)}$ \\
PM10 & 100 & 100 & 24 horas $^{(1)}$ \\
& 150 & 150 & MAA $^{(2)}$ \\
\hline
\end{tabular}

(1) não deve ser excedido mais que uma vez ao ano (2) Média aritmética anual ${ }^{(3)}$ MGA Média geométrica anual. 
Convém ressaltar que o Padrão de Qualidade do Ar adotado no Brasil não faz referencia ao $\mathrm{PM}_{2,5}$.

Nos anos cinqüenta, os níveis de poluição do ar na maioria das cidades da Europa e da América do Norte era de dez a cinqüenta vezes maior do que nos dias de hoje. Avanços na tecnologia para controle das emissões de poluentes como, por exemplo, a instalação de catalisadores em escapamentos de automóveis, e de filtros em indústrias, contribuíram para reduzir os níveis do material particulado e de outros poluentes através dos anos, apesar do aumento do uso da combustão por atividade pessoal, industrial e comercial. Por exemplo, nos Estados Unidos da América, durante o período compreendido entre 1986 e 1995, a média anual de emissão e a concentração ambiental de partículas com diâmetro aerodinâmico menor que $10 \mu \mathrm{m}\left(\mathrm{PM}_{10}\right)$, diminuiu $22 \%$ e $17 \%$, respectivamente; e a média de emissão anual e concentração ambiental de dióxido de enxofre $\left(\mathrm{SO}_{2}\right)$ diminuiu de $18 \%$ e $37 \%$ respectivamente (“USEPA”, 1996a).

Apesar da redução geral no nível dos poluentes, estudos recentes mostraram que as concentrações de partículas no ar ambiente estão associadas a uma ampla gama de efeitos sobre a saúde humana, incluindo aumento de internações hospitalares por patologia respiratória (POPE, 1991; LIPFERT; HAMMERSTROM, 1992; THURSTON et al., 1992); BURNETT et al., 1994; SCHWARTZ 1994c,d; BRAGA et al., 1999: BRAGA et al., (2001); 
visitas a unidade de emergência por patologia respiratória (SAMET et al., 1981; SUNYER et al., 1993; DELFINO, 1997; LIN et al., 1999); exacerbação de episódios de asma (WHITTEMORE; KORN, 1980; BATES et al., 1990; OSTRO et al., 1991; POPE; DOCKERY, 1992; ROEMER et al., 1993); aumento da incidência e da duração de sintomas respiratórios (BRAUNFAHRLANDER et al. 1992; HOEK; BRUNEKREEF, 1993; ROEMER et al., 1993); decréscimo na função pulmonar (DOCKERY et al., 1982; CHESTNUT et al., 1991; POPE et al., 1991; HOEK; BRUNEKREEF, 1993, 1994; KOENIG e al.,1993; POPE E KANNER, 1993); restrição de atividades de trabalhadores adultos e aumento do absenteísmo escolar (OSTRO, 1983,1987,1990; OSTRO; ROTHSCHILD, 1989; RANSOM; POPE, 1992); e aumento de mortalidade (SCHWARTZ 1991a,b; 1993, 1994a,b; DOCKERY et al., 1992; POPE et al., 1992; SCHWARTZ; DOCKERY, 1992a,b; ITO et al., 1993; KINNEY et al., 1995; MOOLGAVKAR et al., 1995, SALDIVA et al., 1994, 1995; SAMET et al., 1995; STYER et al., 1995; ANDERSON et al., 1996; BACHAROVA et al., 1996; BALLESTER et al., 1996, 1997; ITO; THURSTON 1996; OSTRO et al., 1996; RAHLENBECK; KAHL, 1996; SCHWARTZ et al., 1996; SPIX; WICHMAN; 1996; SUNIER et al., 1996; TOULOMI et al., 1996; VERHOEFF et al .,1996; ZMIROU et al., 1996; BORJA-ABURTO et al., 1997; MICHELOZZI et al., 1998).

A questão crucial que se apresenta é se os padrões de qualidade de ar preservam a saúde pública. Algumas revisões realizadas nos anos setenta e oitenta sugeriam que havia importantes efeitos sobre a saúde apesar da 
concentração dos poluentes se apresentar aquém dos padrões de segurança (SHY, 1979: BATES, 1980; WARE et al., 1981). Os estudos realizados em Santa Clara, Califórnia (FARLEY, 1990), em Detroit, EUA (SCHWARTZ, 1991), no Vale de Utah, EUA (POPE et al., 1992), na Filadélfia, EUA (SCHWARTZ; DOCKERY, 1992a), em Steubenville, Ohio, EUA (SCHWARTZ; DOCKERY, 1992b), em Seatle, EUA (SCHWARTZ et al., 1993), e em São Paulo (SALDIVA et al., 1994; SALDIVA et al., 1995; LIN, 1997; EL KHOURY MIRAGLIA, 1997; BRAGA, 1998), e os estudos de coorte realizados por DOCKERY et al. (1993) e POPE et al. (1995a), corroboraram essa idéia. Esses estudos mostraram a dificuldade de estabelecer padrões de qualidade de ar adequados para a proteção da população mais susceptível à poluição atmosférica.

DE KONNING et al. (1985) questionavam: para a grande maioria das pessoas a poluição do ar está somente associada à combustão de combustíveis fósseis em regiões urbanas extremamente desenvolvidas e que necessitam de alto consumo de energia por habitante. Qual a severidade e a extensão dos problemas à saúde associados à poluição por combustão de biomassa em áreas rurais dos paises em desenvolvimento?

\subsection{Queima da Biomassa e repercussão sobre a Saúde}

Os impactos da poluição do ar sobre a saúde, causados pelos incêndios florestais no sudoeste asiático em 1997/1998 foram sérios e 
extensos. Estimativas sugerem que 20 milhões de pessoas apresentaram episódios de afecção respiratória aguda, o que provocou aumento de visitas às unidades de emergência hospitalar, demandou a quantia de um bilhão e quatrocentos milhões de dólares de custos para tratamento de saúde da população afetada e despertou a atenção das autoridades sanitárias de todo o planeta. (GEO-2000, 2001a).

Porém estudos epidemiológicos prévios em comunidades expostas a fumaça proveniente da queima de biomassa em ambientes internos já indicavam uma relação consistente entre a exposição e um aumento de sintomas respiratórios, aumento de doenças respiratórias e decréscimo de função pulmonar na população exposta. Um número menor de estudos também indicava uma associação entre exposição a fumaça proveniente da combustão de biomassa e visitas às unidades de emergência. Não havia estudos conclusivos mostrando a associação entre poluição do ar gerada pela queima de biomassa e mortalidade aguda. Todavia, considerando que a poluição do ar produzida pela queima de biomassa é devida principalmente ao material particulado fino e ultrafino, o manual da Organização Mundial da Saúde (OMS) para queima de vegetação, em 1999, sugere que há impacto sobre a mortalidade diária, admissões hospitalares, visitas a emergência e ao ambulatório e sobre a função pulmonar (WHO, 1999). 


\subsubsection{Queima de Biomassa Em Ambientes Internos e Agravos à Saúde}

Os efeitos sobre a saúde decorrente da exposição por longos períodos à fumaça produzida pela queima de biomassa em ambientes fechados foram bem documentados nos países em desenvolvimento, onde mulheres permanecem várias horas cozinhando em fogões sem abertura para eliminar a fumaça para o exterior. Estes estudos indicam que a exposição à fumaça proveniente da queima de biomassa associa-se ao desenvolvimento de doença pulmonar crônica em adultos (PADMAVATI; PATHAK, 1959; MASTER, 1974; ANDERSON, 1979; PANDEY, 1984a; PANDEY, 1984b; MALIK, 1985; NARBOO et al., 1991; BEHERA et al., 1991; BEHERA et al., 1994; QURESHI, 1994; PEREZ-PADILLA et al., 1996; DENNIS et al., 1996; ALBALAK et al., 1999;) bronquiectasias e fibrose pulmonar (ANDERSON, 1976), infecções respiratórias em crianças (KOSSOVE, 1982; CAMPBELL et al., 1989; PANDEY et al., 1989; COLLINGS et al., 1990; MORRIS et al., 1990; ARMSTRONG; CAMPBELL, 1991; MTANGO et al., 1992; JOHNSON; ADERELE, 1992; DE FRANCISCO et al., 1993; VICTORA et al., 1994; WESLEY; LOENING, 1996; LOPESBRAVO et al., 1997; SMITH et al., 2000), exacerbação de sintomas respiratórios (ELLEGARD, 1996); aumento da incidência de asma em adultos e crianças (AZIZI et al., 1995; NOORHASSIM et al., 1995; MOHAMMED et al., 1995; PISTELLY, 1997), diminuição da função pulmonar em crianças (GHARAIBEH, 1996). Estudos recentes sugerem uma 
associação da queima da biomassa em ambientes fechados com tuberculose pulmonar (GUPTA et al., 1997; MISHRA et al., 1999a; PEREZPADILLA et al., 2001.) Essa associação, se confirmada, teria uma substâncial implicação em saúde publica. A exposição à fumaça originada pela queima da biomassa pode explicar a significativa diferença encontrada na Índia, uma vez que $59 \%$ dos casos são provenientes da zona rural e $23 \%$ dos casos provenientes da zona urbana (MISHRA et al., 1999a). A exposição à fumaça pode ser um fator adicional na relação miséria/tuberculose até agora somente explicada pela má nutrição, aglomeração de pessoas e acesso inadequado a serviços de saúde. (MISHRA et al., 1999a). Estudos mostram associação com recém natos de baixo peso (BOY et al., 1999) possivelmente em conseqüência de altos teores de monóxido de carbono em ambientes fechados ( DARY et al., 1981: NARBOO et al.,1991). A combustão de biomassa em ambientes internos produz irritação nos olhos (ELLEGARD, 1997), pode causar catarata (MOHAN et al., 1989), diminuição da acuidade visual e levar a cegueira (MISHRA et al., 1999b). Até o presente momento os dados coletados não indicam uma associação entre o risco de câncer e altos níveis de exposição à fumaça da queima de biomassa. Apesar da fumaça proveniente da queima de biomassa ser potencialmente carcinogênica, ainda assim seu poder carcinogênico é menor do que a fumaça proveniente queima do combustível de veículos automotivos (BRUCE et al., 2000). 
Estudos indicam que a fumaça produzida pela queima de biomassa em ambientes fechados interfere no mecanismo mucociliar e diminui as propriedades antibacterianas dos macrófagos pulmonares provocando nesses, um decréscimo do poder de fagocitose (FICK et al., 1984; HOUTMEYERS et al., 1999).

\subsubsection{Queima de Biomassa em Ambientes Abertos e Agravos à Saúde}

Como relatamos anteriormente os incêndios florestais ocorridos no sudoeste asiático em 1997/1998 propiciaram um amplo campo de estudos para avaliação dos efeitos agudos produzidos pela poluição do ar devido à queima de biomassa.

A Indonésia, localizada no sudoeste asiático, é o maior arquipélago do mundo com uma população de 200.000 .000 de habitantes, e uma área de 1.900.000 quilômetros quadrados. Consiste de cinco principais ilhas Sumatra, Kalimantan (Bornéu), Java, Slaweski e Irian Java - e mais dezessete mil pequenas ilhas. Em 1997, em virtude do fenômeno "El Niño", 1500 incêndios florestais queimaram 300.000 hectares de florestas na Indonésia, desde junho de 1997 até outubro de 1997, principalmente nas ilhas de Kalimantan (Bornéu) e Sumatra, o que gerou uma intensa névoa que afetou paises vizinhos por vários meses, provocando desastres secundários tais como acidentes com aeronaves e colisões marítimas. Os 
incêndios ocorridos no sudoeste asiático em 1997/1998 elevaram a concentração de poluentes no ar, na região atingida a níveis bem mais altos que os geralmente aceitos pelos manuais de qualidade de ar. As concentrações de material particulado na névoa eram substâncialmente mais elevadas do que as dos poluentes gasosos, o que pode indicar que o material particulado venha a ser a grande preocupação em relação a queimadas em vegetação. Estudos indicam que visitas ao hospital relacionadas a patologias respiratórias aumentaram de forma consistente. 0 incêndio expôs a população a altos níveis de poluentes excedendo àqueles preconizados como aceitáveis pelos manuais da Organização Mundial de Saúde. Em algumas regiões os níveis dos poluentes atingiram níveis quatro a oito vezes maiores que o preconizado. (Figura 1)

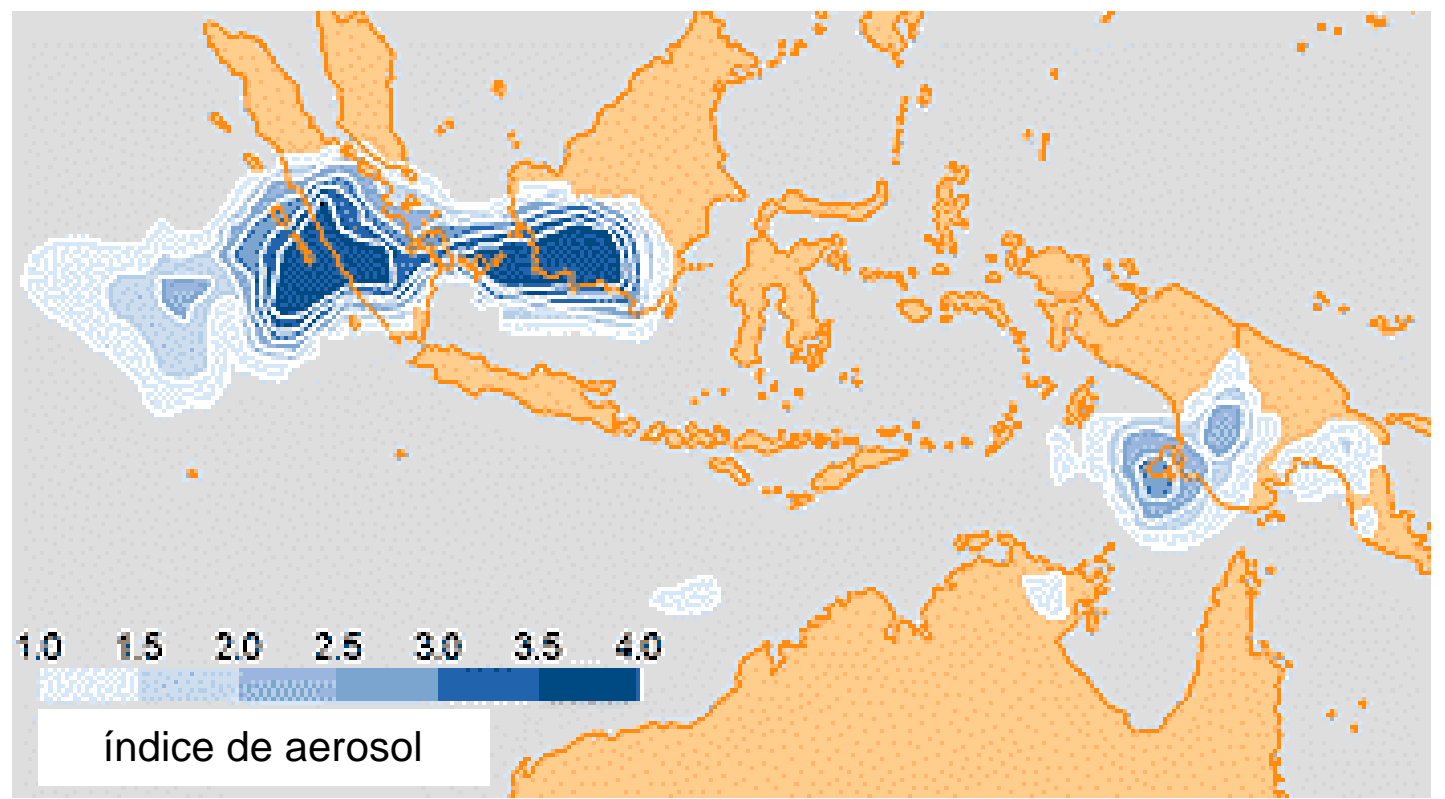

Figura 1. A névoa sobre a Indonésia em 19/10/1997, causada pelos incêndios florestais (GEO-2000, 2001b). 
Segundo a Secretaria Central de Estatística da Indonésia, entre Setembro e Outubro de 1997, em oito províncias do país, aumentou a incidência de asma brônquica, bronquite crônica e infecção respiratória aguda. A população afetada era de 12.360.000 habitantes e houve 1.802.340 casos de asma brônquica, bronquite crônica e infecção respiratória aguda. As patologias respiratórias motivaram 36.462 visitas aos serviços de emergência, 15.822 internações, 2.446 .352 dias de trabalho perdidos.

Em varias províncias, o TSP (Total de Partículas em Suspensão), excedeu o limite de $260 \mu \mathrm{m} / \mathrm{m} 3$ (considerado como aceitável), entre 3 e 15 vezes. Encontrou-se grande concentração de material particulado com diâmetro que variava entre 0,5 e $5 \mu \mathrm{g}$ em áreas próximas às regiões mais afetadas pelo incêndio. (DAWUD, 1999).

Na Malásia crianças tiveram aumento de crises agudas de asma, e a função pulmonar em escolares decresceu durante o período agudo da névoa (WHO, 1998).

O Ministério da Saúde de Singapura monitorou a qualidade do ar em 15 estações durante o episódio da névoa em 1997. O "Pollutant Standard Index" (PSI) foi acima de 100 por 12 dias com pico de 138. A relação entre o PSI e o $\mathrm{PM}_{10}$ é a seguinte: 100 de PSI corresponde aproximadamente a 150 $\mu \mathrm{g} / \mathrm{m} 3$ de $\mathrm{PM}_{10}$ ("USEPA", 1984). Foi encontrado um percentual de $94 \%$ de partículas na névoa com diâmetros inferiores a $2,5 \mu \mathrm{g} / \mathrm{m}^{3}$. Na ultima semana 
de setembro quando os níveis de material particulado atingiram o pico, a vigilância sanitária de Singapura relatou um aumento de $30 \%$ em atendimentos ambulatoriais relacionado com patologias respiratórias. Um aumento nos níveis do $\mathrm{PM}_{10}$ de $50 \mu \mathrm{g} / \mathrm{m}^{3}$ para $150 \mu \mathrm{g} / \mathrm{m}^{3}$ estava significativamente associado com um aumento de 13\%, 19\% e 26\% em infecção respiratória aguda, asma e rinite respectivamente (BRAUER; HISHAM-HASHIM, 1998).

Na região central de Kalimantan (Bornéu), uma das áreas mais afetadas pela névoa por um período de seis meses, a partir de julho de 1997, o número de pacientes hospitalizados com pneumonia em setembro foi trinta e três vezes maior do que nos doze meses prévios. Relatórios do Hospital Distrital de Jambi (Sumatra) mostram que no mês de setembro houve um aumento de internações por bronquite, laringite aguda e bronquiectasias, de 1.6, 8.0 e 3,9 vezes, respectivamente, em relação à média histórica.

Em Jambi (Sumatra), uma amostra de 539 indivíduos respondeu um questionário com o objetivo de avaliar os efeitos da poluição do ar sobre a população. Desses, 532 indivíduos $(99,7 \%)$ relataram algum tipo de sintoma, e $491(91,1 \%)$ referiram sintomas respiratórios. Os sintomas relatados foram considerados de média intensidade, mas a maioria dos entrevistados relatou mais de um sintoma e $85,9 \%$ relataram mais de 10 sintomas. Os 
entrevistados com idade acima de 60 anos referiram sintomas severos e relataram piora significante na qualidade de vida. (KUNII, 1999).

O sul da Tailândia foi coberto pela fumaça oriunda do incêndio durante dois meses, entre setembro e outubro de 1997. Houve um substâncial aumento da morbidade respiratória que provocou aumento das internações hospitalares e de consultas ambulatoriais. A diferença percentual entre as internações hospitalares/consultas ambulatoriais da região sul (afetada) e da região norte (controle) foi 26:18 para todas as consultas por doenças respiratórias, 33:18 para todas as admissões por doenças respiratórias, 36:18 para admissão por pneumonia, 40:28 para admissão por doença pulmonar obstrutiva crônica e 12:9 para admissão por asma. Os relatórios mensais mostraram que a morbidade por doenças respiratórias aumentou durante o episódio da névoa em aproximadamente 45.000 visitas ambulatoriais e 1.500 admissões hospitalares no sul da Tailândia. Modelos de análise de regressão demonstraram uma significante associação entre a admissão hospitalar por doença respiratória e níveis mensais de $\mathrm{PM}_{10}$. Elevação de $1 \mu \mathrm{g} / \mathrm{m}^{3}$ na média mensal de $\mathrm{PM}_{10}$ significava aumento no número de admissões hospitalares. Esse aumento era de $85,28,13,13$, para doença respiratória em geral, pneumonia, doença pulmonar obstrutiva crônica e asma brônquica, respectivamente (PHONBOON et al., 1999). 
TAN et al. (2000) avaliaram em Singapura, a contagem de leucócitos em trinta voluntários (militares) sem doença prévia, utilizando amostras de sangue periférico, comparando o período da névoa (29/09 a 27/10/1997), com o período após a névoa (21/11 a 5/12/1997). O resultado mostrou que durante o período de poluição do ar houve um aumento significante no número de leucócitos devido a um aumento do percentual de polimorfonucleares com associação máxima no dia, e um dia de defasagem para o $\mathrm{PM}_{10}$ e três e quatro dias de defasagem para o $\mathrm{SO}_{2}$ em relação ao evento. Os autores concluem que a poluição atmosférica causada pela queima de biomassa está associada a um aumento da contagem de células brancas no sangue periférico em virtude de um aumento na liberação dos precursores dos polimorfonucleares pela medula óssea e sugerem que essa resposta pode contribuir para a patogênese da morbidade cardiorrepiratória associada a episódios agudos de poluição do ar.

Além do episódio do sudoeste asiático existem estudos limitados correlacionando exposição da população a queima de biomassa a céu aberto.

Segundo a WHO (2000b) durante os incêndios na floresta amazônica em Alta Floresta, em 1997, houve um aumento em 20 vezes da procura a ambulatórios médicos por doenças respiratórias.

LONG et al. (1998), avaliaram 428 indivíduos portadores de obstrução de vias aéreas moderada e severa após esses indivíduos serem 
expostos durante duas semanas a poluentes gerados pela queima de produtos agrícolas (palha, resíduos agrícolas). Durante a exposição a média do $\mathrm{PM}_{10}$ nas vinte e quatro horas aumentou de $15-40 \mu \mathrm{g} / \mathrm{m}^{3}$ para $80-110$ $\mu \mathrm{g} / \mathrm{m} 3$. Trinta e sete por cento da população exposta não apresentou sintomas. $42 \%$ apresentaram sintomas (tosse, sibilos, dispnéia) ou referiram mal estar devido a poluição do ar, 20\% referiram desconforto respiratório. Os sintomáticos eram em sua maior parte mulheres e ex-fumantes, indivíduos portadores de asma brônquica e de bronquite crônica. Esses resultados sugerem que indivíduos com doenças respiratórias pré-existentes são particularmente sensíveis.

CHEW et al. (1995) analisando as queimadas em Singapura ocorridas em 1994, mostraram uma associação entre o aumento do $\mathrm{PM}_{10}$ e um aumento de visitas aos serviços de emergência por crianças asmáticas. Durante o período de névoa os níveis de $\mathrm{PM}_{10}$ foram $20 \%$ maiores que a média anual. Apesar de não terem feito um estudo de séries temporais, os autores sugerem que essa associação permanece significante com concentrações de $\mathrm{PM}_{10}$ acima de $158 \mu \mathrm{g} / \mathrm{m} 3$.

DUCLOS (1990) avaliou o impacto do número de visitas a emergência após o grande incêndio de florestas na Califórnia em 1987. Depois de aproximadamente duas semanas e meia de queimadas, entre 30 de agosto e 15 de setembro de 1987, o TSP atingiu níveis de $1000 \mu \mathrm{g} / \mathrm{m}^{3}$, e o $\mathrm{PM}_{10}$ atingiu níveis de até $237 \mu \mathrm{g} / \mathrm{m} 3$. Comparando a procura diária aos serviços 
de emergência médica entre o período de seis meses anteriores ao evento e o período citado acima concomitante ao fogo, foi encontrado significativo aumento de visitas em razão de patologia respiratória: asma, aumento de 40\%; doença pulmonar obstrutiva crônica, aumento de 30\%; laringite, aumento de 60\%; sinusite, aumento de 30\%; outras infecções respiratórias, aumento de $50 \%$.

GREENBURG (1962) apud ANDERSON (1999), menciona um episodio ocorrido em Nova York, no dia três de novembro de 1952, onde fumaça proveniente de queima de floresta "apagou o sol". Nesse dia houve um aumento de mortalidade de $20 \%$ em relação à média diária observada no mês.

Os bombeiros que atuam em incêndios florestais compreendem um grupo ocupacional de indivíduos com alta exposição a queima de biomassa (REINHARDT; OTTMAR, 1997). Estudos realizados com esses bombeiros indicam uma associação entre exposição ao material particulado e efeitos agudos sobre o sistema respiratório, como tosse, sibilos, irritação na mucosa nasal, na garganta, nos olhos e diminuição de parâmetros da função pulmonar (CVF, FEV 1 , FEF $25-75$ ) (ROTHMAN et al., 1991; LIU et al., 1992; HARRISON et al., 1995; SERRA et al., 1996; BETCHLEY et al., 1997). Estudos prospectivos mostraram que esses efeitos podem ser reversíveis após o individuo afastar-se da exposição à fumaça. 
Devemos considerar, entretanto, que a policia florestal é uma parcela da população hígida, sem doenças prévias, e em principio, bem mais saudável que a média da população em geral. É razoável supor que os impactos sobre a saúde dos bombeiros levam a uma forte evidência de que efeitos similares podem ser observados na população geral em exposições semelhantes ou menores.

\subsubsection{Principais Produtos Emitidos pela Queima da Biomassa, suas Características Físico-químicas e seus Efeitos sobre os Seres Vivos}

Como já foi visto na tabela 1 existem diversos poluentes direta e indiretamente produzidos pela combustão da biomassa. WARD (1999) avaliou os diversos produtos emitidos pela queima da biomassa que poderiam apresentar efeitos sobre a saúde da população exposta. Esses produtos foram categorizados por WARD da seguinte forma:

1. Material Particulado

2. Hidrocarbonetos Policíclicos Aromáticos

3. Monóxido de carbono

4. Aldeídos

5. Ácidos Orgânicos

6. Compostos Orgânicos Voláteis e Semivoláteis (COVs)

7. Compostos de Nitrogênio e Enxofre

8. Ozônio

9. Outros gases

10. Fração Inorgânica da Partícula 
Como as medidas realizadas no nosso estudo focalizaram a fração particulada da queima de biomassa, serão feitas algumas considerações sobre as características físico-químicas e a toxicidade dos produtos da combustão da biomassa, porém com ênfase ao material particulado.

\subsubsection{Material Particulado}

Material particulado é o termo usado para descrever uma complexa mistura de partículas sólidas e líquidas em suspensão no ar, de origem natural ou antropogênica. O tamanho, a composição química, e outras propriedades físicas e biológicas dependem da origem (fonte) e das transformações atmosféricas sofridas pelas partículas. A descrição mais comumente utilizada para caracterizar o material particulado quanto ao tamanho é o diâmetro aerodinâmico, definido como o diâmetro de uma esfera densa que tem a mesma velocidade de sedimentação da partícula em questão (DOCKERY; POPE, 1994). O diâmetro pode variar entre 0,002 $\mu \mathrm{m}$ e $100 \mu \mathrm{m}$. As partículas grandes com diâmetro acima de $100 \mu \mathrm{m}$ não permanecem por muito tempo em suspensão e tendem a se precipitar rapidamente. As gotas de chuva são um exemplo. As partículas de maior importância para os aspectos físico-químicos da atmosfera e para a saúde humana são as de diâmetro compreendido entre 0,002 a $10 \mu \mathrm{m}$. Com base no seu diâmetro as partículas são classificadas em três classes: 
a) ultrafinas ou núcleo de Aitken: partículas com diâmetro menor que $0,1 \mu \mathrm{m}$

b) fina ou de acumulação: partículas com diâmetro entre 0,1 e 2,5 $\mu \mathrm{m}$

c) grandes ou grossas (coarse mode): partículas com diâmetro maior que $2,5 \mu \mathrm{m}$.

As partículas de maior tamanho são normalmente produzidas por processos mecânicos como vento ou erosão.Como característica, elas são grossas e assim são retiradas da atmosfera por sedimentação, exceto em dias de vento quando a sedimentação é balanceada pela reentrada dessas partículas na atmosfera. Elas também podem ser removidas pela chuva. Sob o ponto de vista químico, a composição das partículas reflete a fonte de origem, com predominância de compostos inorgânicos para as derivadas do solo e da névoa marinha. São também encontradas partículas biológicas com predominância de compostos orgânicos como o pólen, esporos, fragmentos de plantas, insetos, etc.

Partículas finas e ultrafinas são preferencialmente emitidas por processos de combustão. Geralmente as partículas finas e ultrafinas são compostas por material carbonáceo, metais, compostos orgânicos e íons sulfatos, nitratos, e amoníacos. As partículas ultrafinas tendem a se agrupar por aglomeração ou por condensação, aumentando o diâmetro aerodinâmico e transformando-se em partículas finas (“USEPA", 1996b). 
A figura 2 apresenta a distribuição média de tamanho das partículas na atmosfera, assim como as principais fontes e os processos de remoção.

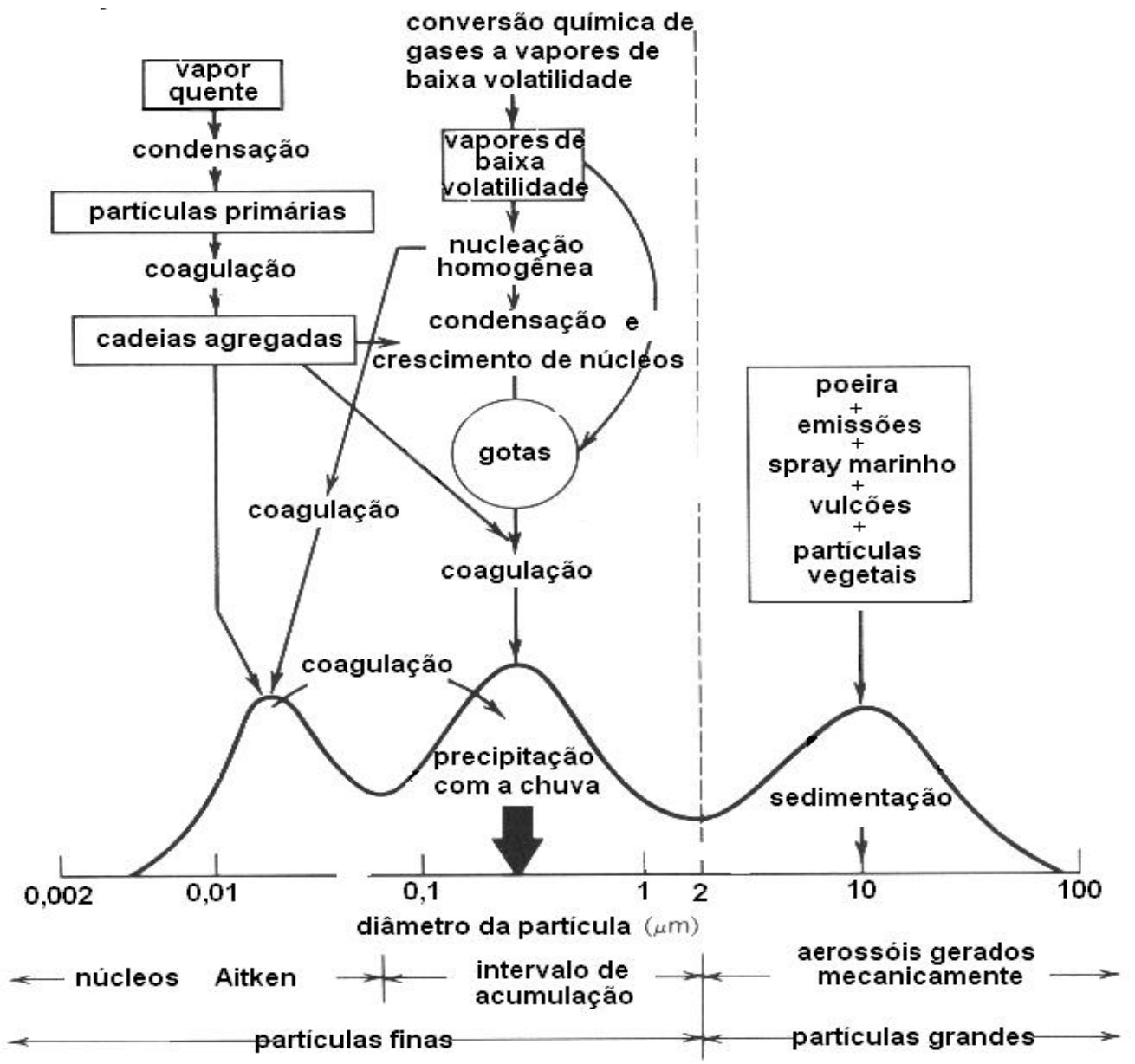

Figura 2. Esquema da distribuição de tamanho das partículas na atmosfera mostrando os três modos, as principais fontes e os principais processos envolvidos na remoção em cada modo (WARK et al., 1998).

Partículas maiores que $10 \mu \mathrm{m}$ são retidas no nariz e nasofaringe, e eliminadas pela deglutição, tosse, espirros e pelo aparelho mucociliar. Partículas menores que $10 \mu \mathrm{m}$ de diâmetro $\left(\mathrm{PM}_{10}\right)$ ficam retidas nas vias aéreas superiores e podem ser depositadas na árvore traqueobrônquica. Partículas menores que 2,5 um de diâmetro $\left(\mathrm{PM}_{2,5}\right)$ depositam-se no 
brônquiolo terminal. Nos alvéolos ocorre deposição de partículas bem menores, com 1 a $2 \mu \mathrm{m}$ de diâmetro. As partículas que atingem as porções mais distais das vias respiratórias são fagocitadas pelos macrófagos alveolares, sendo posteriormente removidas pelo aparelho mucociliar ou pelo sistema linfático (BASCOM et al., 1996; WHO, 1999).

Não está totalmente explicado o mecanismo pelo qual o material particulado produz lesões teciduais no sistema respiratório. Estudos utilizando animais de laboratório mostraram que partículas que apresentam citotoxicidade in vitro também diminuíram as defesas contra as infecções (HATCH et al., 1985). O $\mathrm{PM}_{10}$ pode, in vitro, induzir a síntese de interleucina 6 , interleucina 8 , e fator de necrose tumoral (TNFa) em células do epitélio respiratório humano. Este fato é dependente da concentração de metais (cádmio, cobre, zinco entre outros) no material particulado (CARTER et al., 1997).

Lavado broncoalveolar em ratos expostos ao material particulado apresenta aumento de celularidade (neutrófilos e eosinófilos) e aumento de produção de interleucinas 4 e 5 (WALTERS et al., 1999).

Diversos estudos epidemiológicos associam os efeitos adversos do material particulado à doença pulmonar inflamatória prévia. Investigações sugerem um papel importante da inflamação na exacerbação de doenças pulmonares e salientam a importância da presença dos neutrófilos na agudização da doença crônica de vias aéreas (MULLEN et al.,1985; THOMPSON et al.,1989). 
Estudos mostram a correlação entre o aumento de neutrófilos e o aumento da responsividade das vias aéreas na asma (HUTSON et al., 1990; PAUWELS et al., 1990). A presença de inflamação pulmonar é um campo propício para início da avaliação dos mecanismos que associa morbidade e mortalidade com a inalação de partículas. SHI et al.(1996a,b) sugerem que os efeitos adversos da poluição do material particulado à saúde, podem ser atribuído a produção de agentes oxidantes intracelulares, que seriam a resposta inicial e que agiriam como um fator estimulante da inflamação como mostra a figura 3.

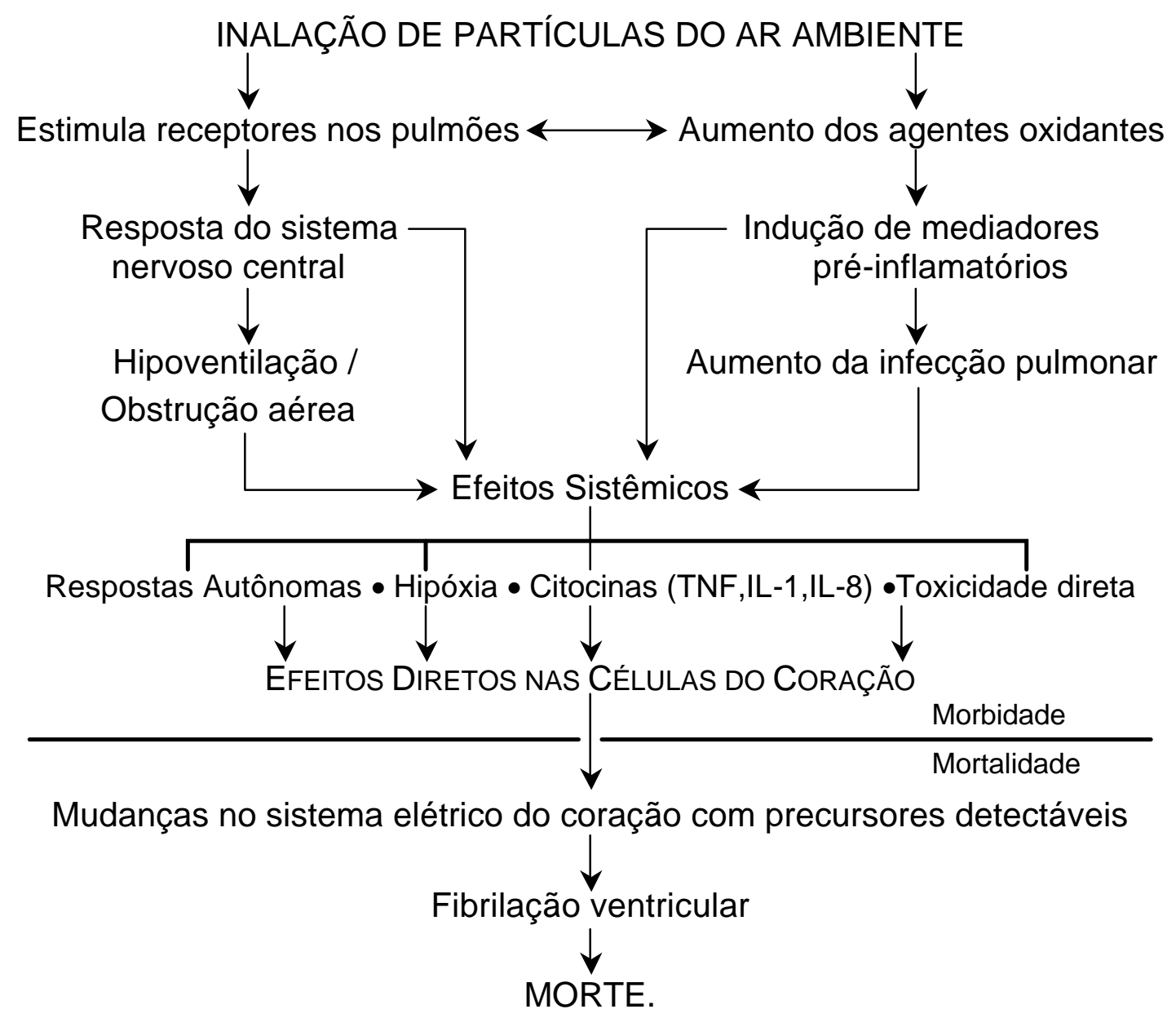

Figura 3. Mecanismos hipotéticos pelos quais a inalação de partículas pode levar a morte (SHI, 1996a,b). 
Cães expostos ao material particulado fino apresentaram alterações eletrocardiográficas mostrando que o material particulado pode induzir alterações cardíacas, além de alterações respiratórias (GODLESK, 1997).

O material particulado é encontrado em elevadas concentrações quando há queima de biomassa. Segundo ARTAXO et al (1993), a emissão de material particulado por queima de biomassa é estimada em 104 Tg/ano (104.000.000.000 kg/ano). A maior parte das partículas emitidas pela queima de biomassa é ultrafina, sendo somente uma pequena fração do tamanho grande como mostra as figuras 4 e 5 (MORAWSKA, 1998; MORAWSKA E THOMAS, 1999, apud WHO, 1999).

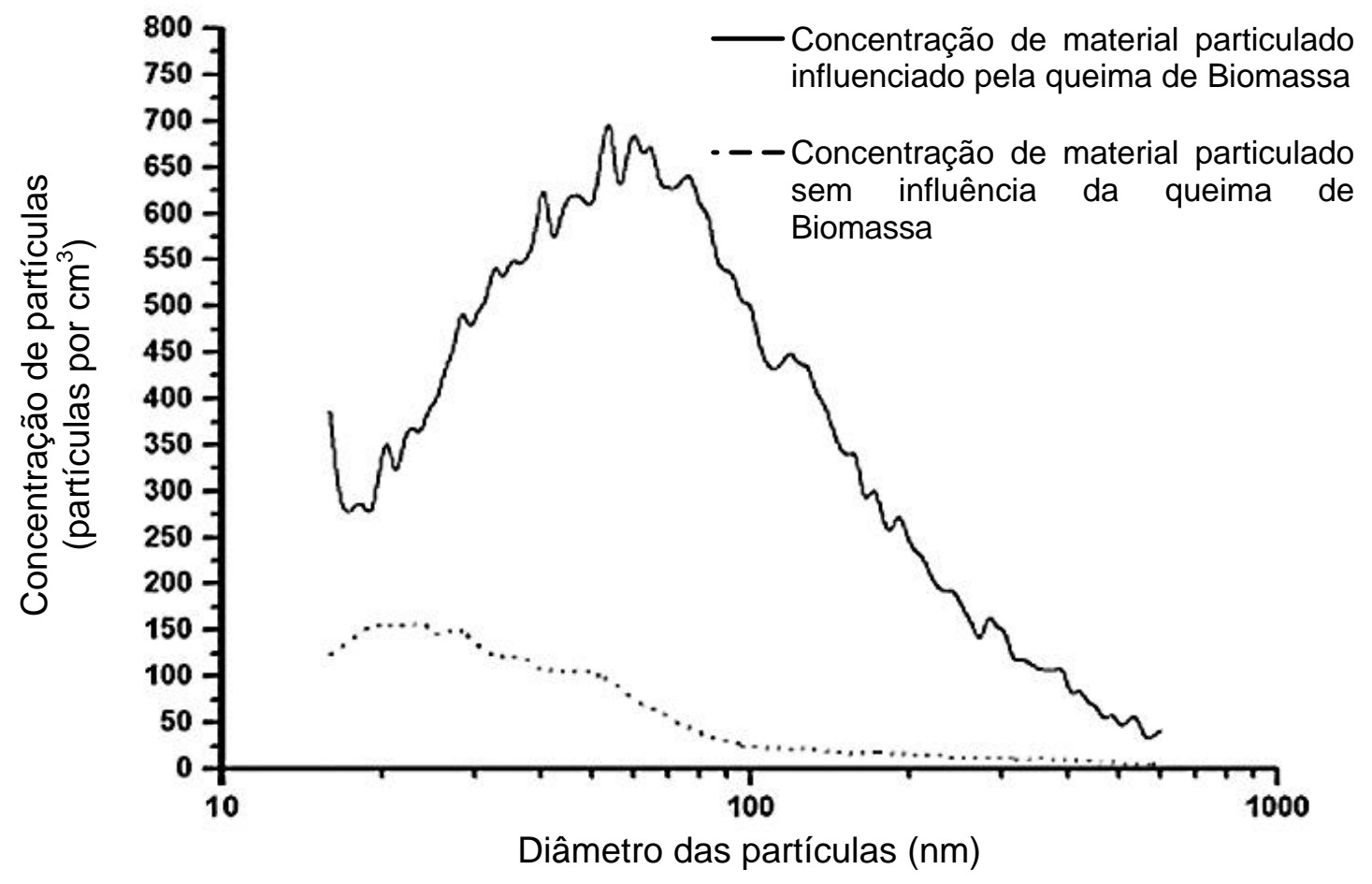

Figura 4. Distribuição do número de partículas de acordo com o tamanho aerodinâmico no centro de Brisbaine, distante $20 \mathrm{~km}$ da queima de biomassa (vegetação rasteira) comparado a distribuição de partículas sem a influência da queima (MORAWSKA, THOMAS, 1999) apud (WHO, 1999). 


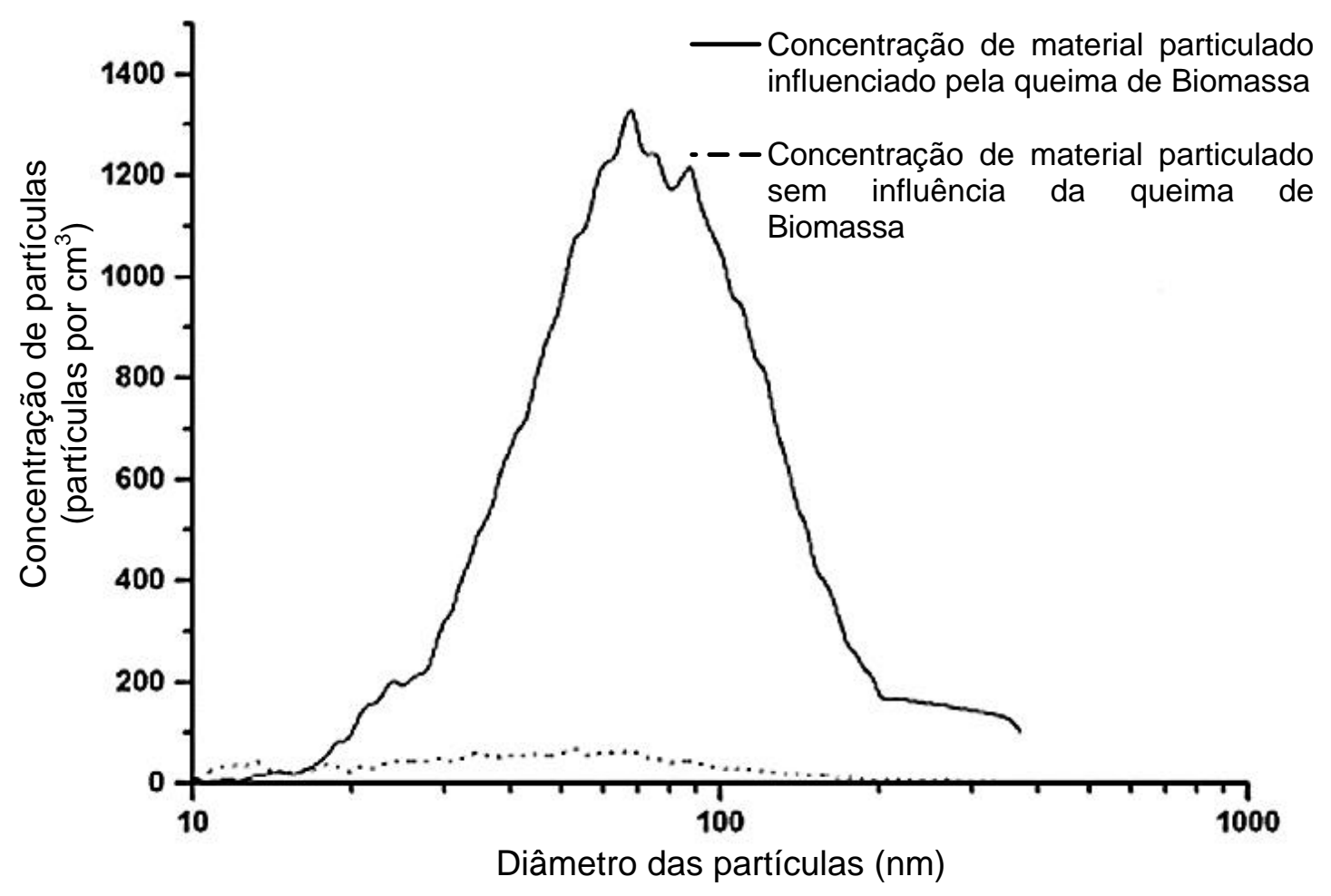

Figura 5. Distribuição do número de partículas de acordo com o tamanho aerodinâmico no centro de Jabiru distante $200 \mathrm{~m}$ de queima de biomassa (grama), e a distribuição de partículas no mesmo local sem a influência da queima (MORASWSKA; THOMAS, 1999) apud (WHO, 1999).

Isto é similar a qualquer outra fonte de combustão. A massa das partículas proveniente da queima de biomassa pode ser dividida em duas classes: a) partículas finas com um diâmetro médio de 0,3 $\mu \mathrm{m}$, geralmente produzidas durante a combustão de material orgânico; b) partículas grandes ou grosseiras com um diâmetro médio maior que $10 \mu \mathrm{m}$. Medidas de material particulado realizadas no solo (WARD ; HARDY, 1989) apud (WHO, 1999) e amostras colhidas em aeronaves mostra que somente uma pequena fração da massa total (menos que dez por cento) é formada por partículas entre dois e dez $\mu \mathrm{m}$ (RADKE et al., 1990) apud (WHO, 1999). 
Segundo a "USEPA" (1998a) o maior percentual do material particulado produzido, seja por combustão de produtos fósseis, seja por combustão de biomassa, é formado por partículas menores que 2,5 $\mu \mathrm{m}$ de diâmetro aerodinâmico, em uma proporção de aproximadamente 90\%.

Segundo WARDY; HARDY (1989) apud (WHO, 1999) a combustão com ausência de chamas libera várias vezes mais partículas finas que a combustão com chamas. As partículas finas apresentam em sua composição de 60 a 70 \% de carbono orgânico. Grosseiramente, podemos considerar de 2 a $15 \%$ de carbono elementar e o restante de material inorgânico (WARD; CORE, 1984) apud (WHO, 1999). Compostos carcinogênicos conhecidos podem estar contidos na fração de carbono orgânico das partículas. ECHALAR; GAUDICHET (1995), estudaram a composição das partículas provenientes da fumaça da queima de biomassa da floresta amazônica e das savanas brasileiras e africanas. Partículas provenientes das savanas eram ricas em $\mathrm{K}, \mathrm{P}, \mathrm{Cl}, \mathrm{Zn}$ e $\mathrm{Br}$, enquanto as provenientes da floresta eram ricas em Si e Ca.

Considerando que o maior número e a maior massa do material particulado proveniente da queima de biomassa são de partículas finas (menor que 2,5 um), sugere-se que, sempre que possível, quantificar a fração $\mathrm{PM}_{2,5}$, em estudos que envolvam a exposição da população à queima da biomassa e riscos a saúde. (WHO, 1999) 
Estudos epidemiológicos já relatados anteriormente mostram relação entre material particulado e agravos à saúde na população urbana. Não há evidência de que as partículas aéreas provenientes de diferentes fontes de combustão tenham diferentes impactos sobre a saúde, e também não há razão para considerar que o material particulado proveniente da queima de biomassa seja menos prejudicial do que o proveniente de qualquer outro tipo de combustão. Logo, é razoável considerar que os resultados que envolvem a população urbana, relacionando material particulado proveniente de combustível fóssil com mortalidade e morbidade, serão também observados na população sujeita ao material particulado proveniente da queima da biomassa.

\subsubsection{Hidrocarbonetos Policíclicos Aromáticos (HPAs)}

Os hidrocarbonetos são uma classe de substâncias orgânicas compostas de hidrogênio e carbono. Dá-se o nome de aromáticos a todos os compostos orgânicos que têm um anel formado por 6 carbonos contendo ligações simples e duplas alternadas na molécula (núcleo benzênico). Chamam-se cíclicos aqueles compostos que apresentam, mais de um anel em sua estrutura. Os hidrocarbonetos policíclicos aromáticos são, pois, compostos orgânicos de carbono e hidrogênio que possuem mais de uma estrutura em anel e, pelo menos um núcleo benzênico e podem ser produzidos por combustão incompleta de material orgânico. A maior fonte de emissão são fontes estacionarias como queima de biomassa utilizada para 
preparo de alimentos ou aquecimento e queima de vegetação, (HOLMAN, 1999).

HPAs são compostos que freqüentemente se encontram na fração orgânica do material particulado fino. Alguns dos compostos dos HPAs são carcinogênicos (MALILAY, 1999). Exposição ao HPAs tem sido relacionados ao câncer de pulmão em trabalhadores de estrada de ferro expostos à fumaça do escapamento de diesel e a câncer de pulmão em trabalhadores em forno de coque e carvão (MALILAY, 1999). Os HPAs são formados a partir de fragmentos de compostos de carbono durante a combustão com chamas da biomassa em presença de baixas concentrações de oxigênio (WHO, 1999). A "USEPA" (1998b) considera como poluentes prioritários para investigação ambiental 15 HPAs, cujas estruturas estão representadas na figura 6 . 
<smiles>c1ccc2ccccc2c1</smiles>

Naftalenc<smiles>c1ccc2c(c1)Cc1ccccc1-2</smiles>

Fluoreno<smiles>c1ccc2c(c1)ccc1c3ccccc3ccc21</smiles>

Criseno<smiles>c1ccc2c(c1)cc1ccc3cccc4ccc2c1c34</smiles>

Benzo(a)pireno<smiles>c1ccc2c(c1)ccc1cc3ccc4ccccc4c3cc12</smiles>

Dibenzo(a.h)antracen<smiles>C1=Cc2cccc3cccc1c23</smiles>

Acenaftilenc<smiles>c1ccc2c(c1)ccc1ccccc12</smiles>

Fenantreno<smiles></smiles>

Pireno<smiles>c1cc2ccc3c4cccc(c2c1)c43</smiles>

Fluoranteno<smiles>c1cc2c3c(cccc3c1)CC2</smiles>

Acenafteno<smiles>c1ccc2cc3ccccc3cc2c1</smiles>

Antraceno<smiles>c1ccc2cc3c(ccc4ccccc43)cc2c1</smiles>

Benz(a)antracen<smiles>c1ccc2cc3c(cc2c1)-c1cccc2cccc-3c12</smiles>

Benzo(k)fluoranteno<smiles></smiles>

Benzo(qhi)perile<smiles></smiles>

Indeno(1,2,3-c,d)antraceno

Figura 6. Fórmulas estruturais dos HPAs considerados como poluentes prioritários pela "USEPA". 
O HPA mais estudado é o benzopireno, cuja substância ativa pode contribuir para o desenvolvimento do câncer na espécie humana. Apesar da presença de substâncias carcinogênicas no material particulado produzido pela combustão de biomassa, dados disponíveis não indicam um aumento do risco de câncer, mesmo em altos níveis de exposição. Essa evidência inclui estudos que mostram exposição em longo prazo a altos níveis de fumaça produzida pela combustão de biomassa utilizada para preparo de alimentos em países em desenvolvimento. Além disso, apesar da fumaça proveniente de a combustão de biomassa ser claramente mutagênica, ainda assim, é menos mutagênica, quando comparada a gases provenientes de veículos a motor, tomando por base à mesma massa (WHO, 1999).

\subsubsection{Monóxido de Carbono}

O monóxido de carbono (CO) é um gás tóxico incolor e inodoro produzido pela combustão incompleta na queima de biomassa e é menos abundante do que $\mathrm{O}^{\mathrm{CO}_{2}}$ e o vapor de água. O $\mathrm{CO}$ é produzido mais abundantemente durante a combustão com ausência de chamas, sendo que imediatamente após a cessação da combustão com chamas são produzidos os níveis máximos de CO. O mecanismo de toxicidade do monóxido de carbono está relacionado a sua grande afinidade com a proteína heme carreadora de oxigênio. Essa proteína apresenta afinidade 220 vezes maior pelo monóxido de carbono do que com o oxigênio e a exposição ao monóxido de carbono produz no indivíduo a carboxihemoglobina $(\mathrm{COHb})$. A 
carboxihemoglobina formada diminui a capacidade do sangue de transportar oxigênio. Atua também desviando a curva de dissociação de hemoglobina para a esquerda levando a uma diminuição da liberação de oxigênio nos tecidos (ELSOM, 1987). Concentrações de CO de 35 ppm durante três a quatro horas eleva o nível de carboxihemoglobina em $5 \%$ e produzem em seres humanos sinais de desorientação e fadiga. Exposição a pequenas e moderadas concentrações de CO prejudica o raciocínio e a percepção, produz cefaléia, diminuição dos reflexos, redução da destreza manual, e sonolência. Em altas concentrações pode levar à morte. Indivíduos com doença cardiovascular ou respiratória pré-existente, crianças, idosos, e grávidas são considerados indivíduos de alto risco (MALILAY, 1999).

\subsubsection{Aldeídos}

Aldeídos são compostos químicos resultantes da oxidação parcial dos álcoois.

São extremamente irritantes para as mucosas do ser humano. Além disso, alguns tipos como o formaldeídos, podem ser carcinogênicos e em combinação com outros irritantes podem levar a um aumento de carcinogenicidade de outros compostos como o HPAs (SHARKEY, 1997). Os principais aldeídos formados durante a queima de biomassa são o formaldeído e a acroleína. O formaldeído e a acroleína são produzidos na combustão incompleta da biomassa, sendo o formaldeído o mais abundantemente produzido. No corpo humano o formaldeídos é rapidamente 
transformado em acido fórmico e eliminado muito lentamente. A exposição aos aldeídos presentes na fumaça diminui a atividade dos macrófagos pulmonares e causa irritação no olho, nariz , garganta e vias respiratórias em geral (MALILAY, 1999).

\subsubsection{5. Ácidos Orgânicos}

Ácidos orgânicos como o acido fórmico e o acido acético são produzidos pela oxidação de aldeídos durante a combustão de biomassa. Produzem irritação das membranas mucosas (SHARKEY, 1997).

\subsubsection{Compostos Orgânicos Voláteis e Semivoláteis (COVs)}

Os compostos orgânicos voláteis compreendem a vasta gama de compostos químicos que têm como elemento comum o carbono, e participam de reações fotoquímicas na atmosfera. O metano é um componente importante dos compostos orgânicos voláteis, mas pela sua importância em relação ao meio ambiente e pela sua contribuição no aquecimento global (efeito estufa), é normalmente considerado separadamente (HOLMAN, 1999). Os COVs podem também ser precursores de formaldeído e ozônio na atmosfera durante dias ensolarados e na ausência de vento. 
Os COVs podem causar irritação nos olhos, tosse, sonolência e sibilos. Alguns, como o benzeno, podem ser carcinogênicos (ELSOM, 1996) apud (MALILAY, 1999).

\subsubsection{Compostos de Nitrogênio e Enxofre}

Os compostos de nitrogênio e enxofre são emitidos proporcionalmente à quantidade desses elementos na vegetação queimada, e à eficiência da combustão. Os compostos de nitrogênio reduzido, como a amônia, são produzidos durante a combustão com ausência de chamas, A combustão com chamas produz preferencialmente dióxido de nitrogênio. YOKELSON (1996); LOBERT et al. (1991) demonstraram que a eficiência da combustão influi na relação amônia/óxidos de nitrogênio.. O dióxido de nitrogênio é um irritante de mucosas. Apresenta baixa solubilidade na água, e, em vista desse fato, no trato respiratório atinge vias aéreas inferiores onde apresenta efeito tóxico (PRYOR; LIGHTSEY, 1981). O dióxido de nitrogênio provoca vários tipos de doenças respiratórias dependendo do tempo de exposição e do nível do poluente, que varia desde uma pequena inflamação, seguindo-se, em ordem crescente de gravidade, traqueítes e bronquites crônicas, enfisema pulmonar, espessamento da barreira alvéolo-capilar e broncopneumonias químicas (SAMET; MARKET, 1999). Estudos epidemiológicos têm demonstrado um aumento de infecções respiratórias em crianças, associado com o dióxido de nitrogênio (SAMET et al., 1992; HASSELBLAD, 1992). PONKA (1991) relata aumento das consultas de 
pacientes adultos e idosos, com crises de asma em Helsinki, associado ao dióxido de nitrogênio e ao ozônio, apesar de os mesmos apresentarem níveis dentro dos padrões estabelecidos como seguros.

Depende também da eficiência da combustão a proporção de liberação entre disulfito de hidrogênio $\left(\mathrm{H}_{2} \mathrm{~S}_{2}\right)$ e dióxido de enxofre $\left(\mathrm{SO}_{2}\right)$. Uma vez na atmosfera o dióxido de enxofre é oxidado e transformado em acido sulfúrico. Essa transformação depende do tempo de permanência no ar, da presença de luz solar, temperatura, umidade e adsorção do gás na superfície das partículas. A permanência prolongada no ar faz com que o dióxido de enxofre e seus derivados -aerossóis ácidos - sejam levados pelos ventos para outras regiões, tendo assim atuação distante das fontes produtoras (CALVERT et al., 1985). . Os aerossóis ácidos encontram-se dissolvidos nas gotas de água presentes na atmosfera e são parte integrante do complexo de particulados inaláveis. $\mathrm{O}$ maior parte do $\mathrm{SO}_{2}$ inalado por uma pessoa em repouso é absorvido nas vias aéreas superiores. A absorção por regiões mais distais do pulmão é geralmente secundária a atividade física, após aumento da ventilação pulmonar (FRANK et al., 1969). Estudos indicam a associação entre o dióxido de enxofre, mesmo em níveis considerados como seguros, e decréscimo da função pulmonar (DOCKERY et al., 1982), asma (DAB et al., 1996) e admissões hospitalares (BATES; SIZTO, 1983), especialmente por doença pulmonar obstrutiva crônica (SUNYER, 1991). 


\subsubsection{Ozônio}

O ozônio presente na troposfera, a porção da atmosfera em contato com a crosta terrestre, é um gás derivado de reações fotoquímicas catalisadas pelos raios ultravioletas da luz solar, envolvendo, como precursores, óxido de nitrogênio $\left(\mathrm{NO}_{\mathrm{x}}\right)$ e compostos orgânicos voláteis (COVs). O ozônio é um potente agente oxidante, é pouco solúvel em água e atinge as porções mais distais do sistema respiratório com facilidade (HATCH et al.,1994).

Em altas concentrações pode reduzir a função pulmonar e reduzir a resistência respiratória a infecções. A população de risco inclui os portadores de doença respiratória crônica. Em baixas concentrações, o ozônio pode causar sintomas como tosse, dispnéia, excesso de escarro, irritação na garganta, náuseas, diminuição da resistência pulmonar a exercícios físicos. A exposição por longo tempo produz diminuição da função pulmonar e doença pulmonar obstrutiva crônica (ELSOM, 1996).

\subsubsection{Outros Gases}

Gases, particularmente as dioxinas, são extremamente persistentes e largamente distribuídos no meio ambiente, porém, são escassos os relatos que associam a toxicidade desses gases com a saúde humana. Os dados que relacionam as dioxinas e a saúde estão baseados em estudos 
ocupacionais e na exposição a produtos químicos contaminados com 2,3,7,8-tetraclorodibenzo-p-dioxina. A exposição à dioxina produziu um aumento de risco de lesões dermatológicas como acne e hiperpigmentação, alteração no metabolismo lipídico, alterações da função hepática, fraqueza generalizada e perda de peso. (MUKERJEE, 1997). Os efeitos sobre a saúde humana resultante da emissão destes compostos pela queima de biomassa ainda não estão determinados (MALILAY, 1999).

\subsubsection{Fração Inorgânica das Partículas}

Os efeitos toxicológicos da fração inorgânica das partículas, proveniente da queima da biomassa, ainda não esta completamente estabelecida. Os efeitos sobre a saúde dependem da substância em questão como, por exemplo, o chumbo, o asbesto, o sulfato, etc. O material inorgânico, presente nas partículas existente na fumaça, depende de diferentes fatores, tais como o conteúdo dos elementos químicos no solo e da bioconcentração dos mesmos na vegetação. Como já foi citado, as partículas provenientes da queima das savanas apresenta diferentes elementos químicos em relação às partículas emitidas pela queima de florestas. 


\subsection{A Cana-de-Açúcar}

Os estudos apresentados anteriormente com queima de vegetação a céu aberto foram motivados por eventos agudos e episódicos. Entretanto existem populações expostas periodicamente a queimadas de biomassa. É o caso das áreas onde se cultiva a cana-de-açúcar. Faremos um histórico dos caminhos percorridos pela cana-de-açúcar e de seu importante papel do ponto de vista econômico e social na História do Brasil.

\subsubsection{Histórico da Cana-de-Açúcar}

A cana-de-açúcar (Saccharum officinarum L) era conhecida no subcontinente indiano desde 3000 a.C. (ENCICLOPÉDIA BARSA, 1997).

A mais antiga menção sobre a cana-de-açúcar foi encontrada em arquivos indianos datados de 1400-1000 a.C. (IRVINE, 1993).

Brandes, em 1956, porém, afirma categoricamente que a Nova Guiné é sem dúvida, o lar original da cana-de-açúcar. Este é o ponto de vista aceito atualmente (BARNES, 1964; IRVINE, 1993).

Historiadores acreditam, que, a partir da Nova Guiné, a cana-deaçúcar espalhou-se seguindo três rotas diferentes em diferentes épocas: 
1) Aproximadamente, no ano 8000 a.C: a cana-de-açúcar foi transportada para as Ilhas Solomon, Nova Caledonia, e New Hebrides.

2) Aproximadamente, no ano 6000 a.C: seguiu em direção a leste a caminho das Filipinas, Indonésia, Bornéu, Java, Malásia, Burma e para a Índia.

3) Entre os anos 550 e 1100 d.C.: seguiu o caminho oeste em direção a Fiji, e de Fiji para Samoa, Tahiti e Havaí, assim como para outras regiões da Oceania.

Essas migrações foram descritas por BRANDES (1958) apud BLACKBURN (1984) e estão ilustradas na figura 7 (BLACKBURN, 1984). 
Por volta de 800 a.C., a cana-de-açúcar foi introduzida na China, a partir da Índia (IRVINE, 1993).

Em 325 a.C. Alexandre, O Grande, ao invadir a Índia, entrou em contato com a cana-de-açúcar e um dos seus generais, Nearco, mencionou um caniço que produzia mel, sem a ajuda das abelhas. O vocábulo original sâncristo sarkara ou sakkara, "areia", "saibro", deu origem às palavras sukkar em árabe, sakharon em grego, zuchero em italiano, sugar em inglês, sucre em francês e açúcar em português (NOVA ENCICLOPÉDIA BARSA, 1997).

Alexandre, o Grande, foi o responsável pela dispersão da cana-deaçúcar, para o leste da Índia, levando-a para a Pérsia, e daí para a Síria e para o Egito (BARNES, 1964).

No século II de nossa era, na Índia, pela primeira vez, obteve-se a conversão do caldo de cana em produto sólido. Depois dos indianos, os persas e os árabes passaram a empregar o açúcar não só como remédio, mas ainda em confeitos, pastéis e bebidas (ENCICLOPÉDIA MIRADOR INTERNACIONAL, 1977)

No século VIII, no período em que dominaram o sul da Europa, os árabes introduziram a cultura de cana-de-açúcar na Espanha, Provença e Sicília, através do Egito. (GRANDE ENCICLOPÉDIA BRASILEIRA DE 
CONSULTAS E PESQUISA, 1988). Nos dois séculos seguintes, o único produtor de açúcar na Europa foi a Espanha. Entre os séculos X e XII, a cidade de Veneza passou a trazer o açúcar do vale Tigre-Eufrates, do Egito e da Síria, e vendia-o a comerciantes europeus, após seu uso ser difundido na Europa, quando os cruzados ao retornarem da "Guerra Santa", no Oriente, exibiam pequenas quantidades de uma substância muito doce, que foi denominada mel pagão. Mas, devido à dificuldade em se obter o açúcar, a quantidade era limitada, o preço era muito alto, e o produto era considerado um verdadeiro símbolo de luxo, somente utilizado por nobres e burgueses ricos.

Por estas razões, no início do século XIV iniciaram-se algumas plantações de cana-de-açúcar no sul da França e na Itália, e em todo o norte da África (ENCICLOPÉDIA DELTA UNIVERSAL, 1980). Ainda no século XIV, a guerra entre Veneza e os Turcos levou à procura de outros centros abastecedores. Surgiram culturas nas ilhas da Madeira de Açores e de Cabo Verde, implantadas pelos portugueses, e nas ilhas Canárias, implantadas pelos espanhóis.

Contudo, foi a América que acolheu a cana-de-açúcar de forma definitiva. Em 1493, Colombo em sua segunda viagem, trouxe mudas de cana-de-açúcar, plantou-as em São Domingos, e as lavouras estenderam-se a Cuba e outras ilhas do Caribe (NOVA ENCICLOPÉDIA BARSA, 2000). 


\subsubsection{A Cana-de-Açúcar no Brasil}

$\mathrm{Na}$ época do descobrimento do Brasil, o açúcar aparece rotulado como "droga de luxo", ao lado da pimenta e outras especiarias. Era adquirido em farmácias, e, por sua origem oriental, apresentava um certo halo místico. Fortalecia o corpo e o espírito, segundo os terapeutas da época, "especialmente o peito, pulmões e garganta". Além de ser aplicado na medicina, usavam-no também os alquimistas na esperança de por meio dele, conseguir a síntese da "pedra filosofal", a cujo toque qualquer substância se transmudaria em ouro. A Europa mudava seus hábitos alimentares, diminuindo o consumo de carne e reforçando o dos vegetais. Ao mesmo tempo, generalizava-se o consumo de café, do chá, e do chocolate, que eram acompanhados de açúcar, condimento usado até no preparo de carnes e de peixes, tornando-se indispensável à mesa civilizada, como a pimenta da Índia e o próprio sal.

Os portugueses, com a experiência adquirida com o cultivo da canade-açúcar na ilha da Madeira introduziram-na no Brasil. O primeiro engenho foi construído em São Vicente, por Martim Afonso de Souza, em 1532. Entre a chegada dos primeiros colonizadores portugueses e a consolidação da agroindústria do açúcar, decorreram aproximadamente sessenta anos. No final do século XVI, o Brasil tinha na Bahia e em Pernambuco duas grandes e prósperas regiões produtoras de açúcar, enquanto São Vicente entrava em 
declínio. Além do clima tropical, o solo favorável e a proximidade dos portos de Salvador e Recife com o mercado consumidor faziam a diferença.

No início do século XVII, o Brasil tornou-se o maior produtor mundial de açúcar, porém o açúcar aqui produzido, após passar por Lisboa, era encaminhado a portos holandeses, onde era refinado e depois distribuído para a Europa. Na realidade, os holandeses eram de fato os controladores desse comércio, pois os armazéns reais de Lisboa não passavam de entrepostos. Proibidos de receber o açúcar brasileiro em Lisboa, após a união entre Espanha e Portugal, ocorrida em 1580, os holandeses decidiram invadir o nordeste brasileiro em 1630, e aqui permaneceram por 25 anos, período no qual aprenderam as técnicas de produzir açúcar, e, após serem expulsos, aliaram-se a produtores estabelecidos nas colônias inglesas e francesas da América Central, fornecendo-Ihes ajuda técnica e financeira. Em pouco tempo aquela região transformou-se em grande produtora, com a vantagem de estar mais próxima do mercado europeu, o que facilitava e barateava o transporte. Com essa concorrência, o açúcar brasileiro perdeu competitividade e a agroindústria açucareira entrou em decadência.

Esse quadro permaneceu até a segunda metade do século XVIII, quando a produção açucareira das Antilhas e da América Central foi seriamente prejudicada por agitações políticas e conflitos sociais, que levaram à independência das colônias européias nessas regiões, a que se acresceu o fato de os holandeses terem perdido o controle do comércio de 
açúcar na Europa. A abertura dos portos no Brasil, em 1808, e a independência, em 1822, também contribuíram para o Brasil recuperar o posto de maior produtor mundial de açúcar, situação essa que permaneceu por pouco tempo. Baixo nível técnico da produção, distância dos principais centros de consumo, significativa expansão do açúcar produzido da beterraba, progressivo aumento da cultura cafeeira, domínio da técnica de cristalização do açúcar por Cuba, levaram a que o Brasil despencasse de primeiro para quinto lugar entre os produtores mundiais de cana-de-açúcar, com menos de oito por cento do total, entre a segunda metade e o final do século XIX.

Somente após a Abolição da Escravatura, a agroindústria açucareira remanejou os recursos utilizados na compra e na manutenção dos escravos, para modernização dos equipamentos e ampliação das usinas. O Brasil, finalmente, entrava na era do açúcar centrifugado, técnica esta já utilizada em Cuba, e na Antilhas desde 1870.

Entre 1900 e 1930, houve aumento de consumo no mercado interno, e somente no nordeste brasileiro, foram instaladas 80 novas usinas. Com as seguidas crises do café, os Estados de São Paulo e Rio de Janeiro voltaramse para o cultivo de cana-de-açúcar e, conseqüentemente para a produção de açúcar. Em 1933 foi criado o Instituto do Açúcar e do Álcool (IAA), cuja função era controlar a produção para manter os preços em um nível adequado, protegendo o produto brasileiro no mercado internacional. Foi 
estabelecido um sistema rígido de cotas, que eram distribuídas entre a diferentes unidades produtoras. Ou seja, cada usina ou engenho só poderia produzir uma determinada quantidade de açúcar. Havia um controle do preço e da produção. Assim, o lucro dependeria de um custo reduzido e um aumento da produtividade, o que contribuiu para que a produção se concentrasse em grandes usinas, com grande capacidade de produção. Essa reordenação da economia açucareira assegurou ao Brasil tornar a ser um dos maiores produtores mundiais de açúcar. (SIMONSEN, 1977; ENCICLOPÉDIA MIRADOR INTERNACIONAL, 1979; BARNES, 1984; BRANDÃO, 1984; COPERSUCAR, 1989a; TOLEDO; GANCHO, 1996; FERLINI, 1998; PRADO Jr., 2000).

\subsubsection{A Cana-de-Açúcar como Fonte de Energia}

Em setembro de 1973, o preço do barril de petróleo no mercado internacional era equivalente a 2,91 dólares. Com a eclosão da Guerra do 'Yom Kippur', conflito no qual se envolveram diretamente Israel, Egito e Síria, geraram-se nessa região graves perturbações de alcance internacional.

O preço do barril de petróleo importado pelo Brasil atingiu a cifra de 12 dólares em janeiro de 1974, caracterizando aquilo que ficou conhecido por primeiro "choque" do petróleo. O período 1979/1980 é identificado como o segundo "choque" do petróleo. Durante o primeiro semestre de 1981, o 
barril custava ao Brasil, 34 dólares. Isso foi resultado da ação da OPEP (Organização dos Países Exportadores de Petróleo), composta, principalmente, pelos grandes países produtores do Oriente Médio. O Brasil, que tinha alocado 469 milhões de dólares com a importação de petróleo em 1972, 600 milhões em 1973, despendeu 2 bilhões de dólares em 1974 e 10,6 bilhões de dólares em 1981. Como conseqüência, a participação das importações de petróleo sobre o total das importações do país passou de cerca de $10 \%$ em 1973 , para $57 \%$ em 1983, abalando seriamente a balança comercial. (MELO; FONSECA, 1981; COPERSUCAR, 1989b; MAGALHÃES et al., 1991; SHIKIDA, 1998).

Ficou evidente, também, a possibilidade de um colapso da economia caso houvesse a interrupção de fornecimento de petróleo. Substituir o diesel e a gasolina por outras fontes de energia foi o objetivo de um programa a ser posto em prática imediatamente. Em 1975, foram apresentados ao Sr. Presidente da República estudos visando à produção de um combustível alternativo e renovável, utilizando diversas fontes de biomassa: sorgo, sacarina, batata doce, mandioca, e a cana-de-açúcar. Além de o Brasil manter sua posição como um dos maiores produtores mundiais de cana-de-açúcar por quatro séculos, aliado a terra abundante e à existência de uma infraestrutura industrial recém-modernizada, a partir de 1974, com a implantação e o reequipamento de várias destilarias anexas a usinas, havia a experiência prévia com o uso de etanol como combustível único para motores de explosão. O emprego do álcool em substituição parcial ou total aos derivados 
do petróleo remonta à época da Primeira Guerra Mundial (1914-1918), sendo lançado em escala comercial, em 1927, o combustível denominado USGA, produzido pela Usina Serra Grande de Alagoas, que se compunha de $80 \%$ de etanol e $20 \%$ de éter. Os baixos preços do petróleo acabaram desestimulando essa e outras iniciativas similares de se consolidar no país a utilização do álcool como combustível em larga escala. No início da década de 1930, houve uma queda acentuada no preço do açúcar no mercado internacional. Como medida de proteção às culturas de cana-de-açúcar, decidiu-se pela obrigatoriedade da mistura de álcool a gasolina na proporção de 5\% de álcool para $95 \%$ de gasolina. Durante a Segunda Guerra Mundial, o álcool foi utilizado como aditivo de $20 \%$ na gasolina, na tentativa de economizar cada barril de petróleo importado. Em 14 de novembro de 1975 foi promulgado do decreto $n^{*} 76593$, que criou o Programa Nacional do Álcool - Proálcool. Em uma primeira fase, ele se concentrou em incrementar as safras agroenergéticas e a capacidade industrial de transformação, sobretudo na produção do álcool anidro para mistura com a gasolina. Essa mistura aumentou gradativamente. Em 1976, a mistura no Estado de São Paulo, no Nordeste, no Estado do Rio de Janeiro e Norte do Paraná ficava entre 10\% e 15\%. Em 1977 atinge 20\% na capital paulista, permanecendo abaixo dessa cifra no restante do país. Em 1978 a mistura chega a 20\% no Nordeste, percentagem que vai se generalizar para todo o país em 1979. Atinge a $22 \%$ em 1980 na cidade de São Paulo, e em 1991, por lei federal em todo o Brasil. Em 1978, após o segundo choque do petróleo, o desenvolvimento da tecnologia em conseqüência do substancial apoio do governo brasileiro, 
possibilitou que surgissem as primeiras frotas com veículos movidos exclusivamente a álcool (PAMPLONA, 1984; MAGALHÃES et al.,1991; ENCICLOPÉDIA AGRÍCOLA BRASILEIRA, 1995; FRENTE PARLAMENTAR SUCROALCOOLEIRA, 1996; ASSOCIAÇÃO DA INDÚSTRIA DO AÇÚCAR E DO ÁlCOOL DO ESTADO DE S. PAULO, 1997; OMETTO, 1998).

A produção de veículos movidos exclusivamente a álcool, atingiu noventa e cinco por cento da produção nacional nos anos oitenta, conforme demonstra o figura 8.

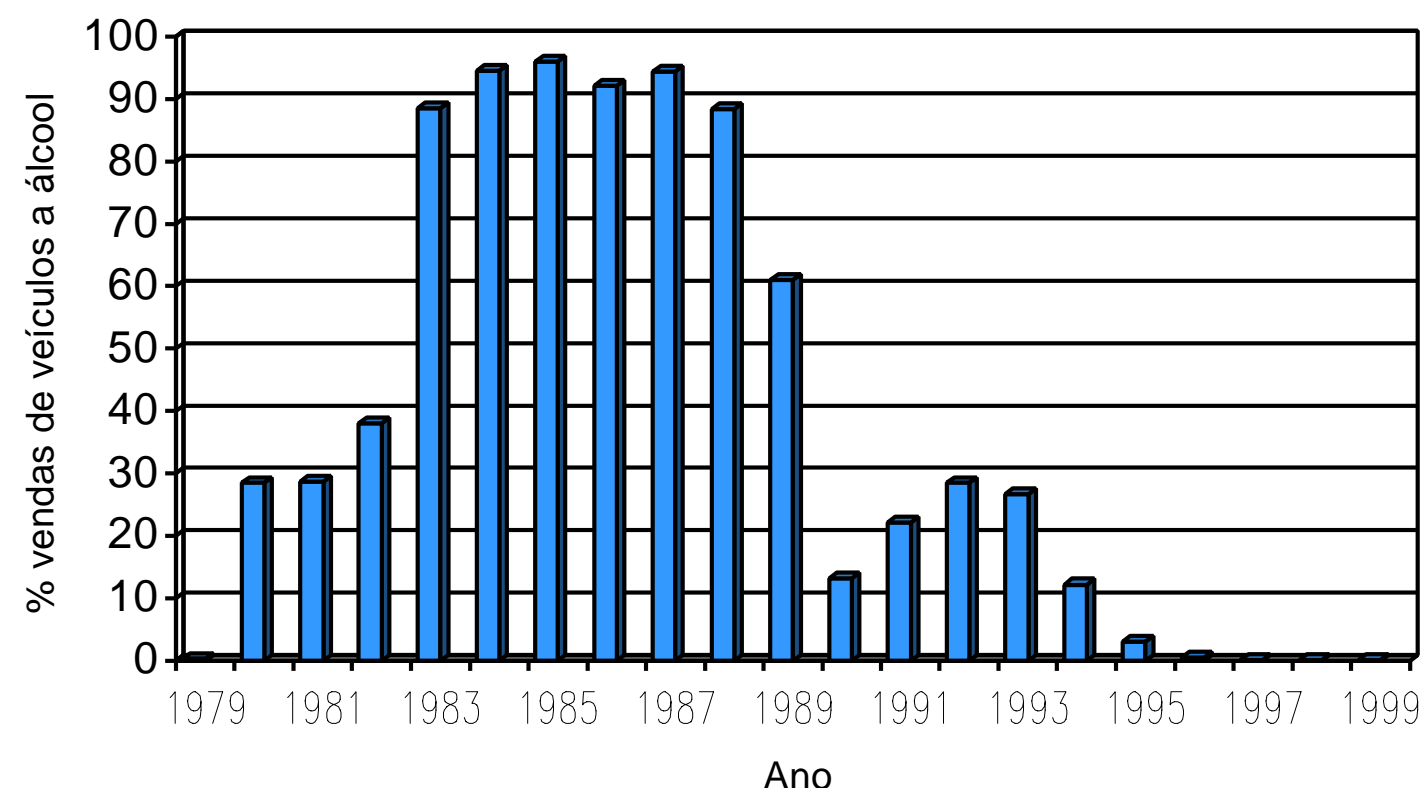

Figura 8. Evolução das vendas de veículos a álcool no Brasil (CARVALHO, 2000). 
A conseqüência imediata desse fato foi o aumento significativo das áreas agrícolas utilizadas para a produção de cana-de-açúcar, substituindo culturas alimentícias tradicionais como, por exemplo, café, milho, algodão, laranja, etc.

As tabelas 5,6,7 e 8 mostram o desempenho da agroindústria da cana-de-açúcar no Brasil, por regiões, entre 1970 e 1997.

Tabela 5. Área total cultivada (milhares de hectares) com cana-de-açúcar no Brasil (BR), nas Regiões Norte-Nordeste (NN), Centro-Sul (CS) e Estado de São Paulo (SP) (FERNANDES, 2000*).

\begin{tabular}{|c|c|c|c|c|}
\hline Ano & BR & NN & CS & SP \\
\hline 72 & 1.541 & 603 & 938 & 620 \\
\hline 73 & 1.644 & 637 & 1.007 & 665 \\
\hline 74 & 1.721 & 697 & 1.024 & 683 \\
\hline 75 & 1.933 & 811 & 1.122 & 760 \\
\hline 76 & 2.032 & 756 & 1.276 & 891 \\
\hline 77 & 2.176 & 823 & 1.353 & 928 \\
\hline 78 & 2.369 & 885 & 1.484 & 1.055 \\
\hline 79 & 2.498 & 901 & 1.597 & 1.146 \\
\hline 80 & 2.676 & 964 & 1.712 & 1.218 \\
\hline 81 & 2.920 & 1.032 & 1.887 & 1.347 \\
\hline 82 & 3.363 & 1.107 & 2.256 & 1.635 \\
\hline 83 & 3.720 & 1.187 & 2.533 & 1.837 \\
\hline 84 & 3.867 & 1.234 & 2.633 & 1.870 \\
\hline 85 & 4.166 & 1.297 & 2.869 & 2.001 \\
\hline 86 & & & & 2.042 \\
\hline
\end{tabular}

Fonte: IAA-PLANALSUCAR, Relatórios Anuais. 
Tabela 6. Área total colhida (milhares de hectares) com cana-de-açúcar no Brasil (BR), nas Regiões Norte-Nordeste (NN), Centro-Sul (CS) e Estado de São Paulo (SP) (FERNANDES, 2000*).

\begin{tabular}{|c|c|c|c|c|}
\hline Ano & BR & NN & CS & SP \\
\hline 80 & 2.608 & 1.036 & 1.572 & 1.008 \\
\hline 81 & 2.826 & 1.119 & 1.707 & 1.121 \\
\hline 82 & 3.084 & 1.137 & 1.948 & 1.281 \\
\hline 83 & 3.479 & 1.223 & 2.256 & 1.513 \\
\hline 84 & 3.656 & 1.245 & 2.411 & 1.580 \\
\hline 85 & 3.812 & 1.237 & 2.575 & 1.666 \\
\hline 86 & 3.952 & 1.296 & 2.656 & 1.680 \\
\hline 87 & 4.314 & 1.568 & 2.746 & 1.727 \\
\hline 88 & 4.184 & 1.359 & 2.825 & 1.785 \\
\hline 89 & 4.153 & 1.458 & 2.696 & 1.704 \\
\hline 90 & 4.273 & 1.493 & 2.780 & 1.812 \\
\hline 91 & 4.211 & 1.416 & 2.795 & 1.852 \\
\hline 92 & 4.203 & 1.377 & 2.826 & 1.890 \\
\hline 93 & 3.864 & 1.040 & 2.824 & 1.896 \\
\hline 94 & 4.345 & 1.206 & 3.139 & 2.173 \\
\hline 95 & 4.559 & 1.261 & 3.298 & 2.259 \\
\hline 96 & 4.827 & & & \\
\hline 97 & 4.877 & & & \\
\hline
\end{tabular}

Fonte: IBGE, via Internet. 
Tabela 7. Álcool total (anidro-hidratado) por safra (milhares de $\mathrm{m}^{3}$ ) no Brasil (BR), nas Regiões Norte-Nordeste (NN), Centro-Sul (CS), e Estado de São Paulo (SP) (FERNANDES, $2000^{*}$ ).

\begin{tabular}{|c|c|c|c|c|}
\hline & BR & NN & CS & SP \\
\hline 70 & 637 & 118 & 520 & 437 \\
\hline 71 & 613 & 76 & 538 & 453 \\
\hline 72 & 681 & 82 & 599 & 500 \\
\hline 73 & 666 & 102 & 564 & 455 \\
\hline 74 & 625 & 116 & 508 & 408 \\
\hline 75 & 879 & 174 & 705 & 506 \\
\hline 76 & 664 & 112 & 552 & 464 \\
\hline 77 & 1.470 & 208 & 1.263 & 1.095 \\
\hline 78 & 2.491 & 411 & 2.079 & 1.812 \\
\hline 79 & 3.395 & 569 & 2.827 & 2.472 \\
\hline 80 & 3.706 & 650 & 3.056 & 2.608 \\
\hline 81 & 4.240 & 826 & 3.414 & 2.834 \\
\hline 82 & 5.823 & 1.186 & 4.635 & 3.815 \\
\hline 83 & 7.864 & 1.130 & 6.735 & 5.391 \\
\hline 84 & 9.244 & 1.595 & 7.648 & 6.023 \\
\hline 85 & 11.820 & 2.021 & 9.799 & 7.624 \\
\hline 86 & 10.516 & 2.215 & 8.301 & 6.190 \\
\hline 87 & 11.454 & 1.786 & 9.668 & 7.329 \\
\hline 88 & 11.713 & 1.754 & 9.960 & 7.724 \\
\hline 89 & 11.881 & 1.980 & 9.901 & 7.775 \\
\hline 90 & 11.783 & 1.807 & 9.975 & 7.959 \\
\hline 91 & 12.681 & 1.777 & 10.904 & 8.560 \\
\hline 92 & 11.737 & 1.672 & 10.065 & 7.922 \\
\hline 93 & 11.277 & 909 & 10.369 & 8.279 \\
\hline 94 & 12.726 & 1.579 & 11.147 & 8.697 \\
\hline 05 & 12.671 & 1.719 & 10.952 & 8.123 \\
\hline 96 & 14.310 & 2.196 & 12.112 & 8.975 \\
\hline 97 & 15.307 & 1.047 & 13.260 & 9.498 \\
\hline
\end{tabular}

Fonte: MIC-IAA até 1985 e AIAA-ESP após 1986.

* NOTA: FERNANDES, A.C. Desempenho da agroindústria da cana-de-açúcar no Brasil (1970-1997). Centro de Tecnologia Copersucar, Piracicaba. Comunicação Pessoal, 2000. 
Tabela 8. Álcool total (na forma de anidro) por safra (milhares de $\mathrm{m}^{3}$ ) no Brasil (BR), nas Regiões Norte-Nordeste (NN), Centro-Sul (CS), e Estado de São Paulo (SP) (FERNANDES, 2000*).

\begin{tabular}{|c|c|c|c|c|}
\hline Ano & BR & NN & CS & SP \\
\hline 70 & 621 & 613 & 508 & 427 \\
\hline 71 & 604 & 73 & 531 & 449 \\
\hline 72 & 668 & 78 & 590 & 494 \\
\hline 73 & 651 & 98 & 553 & 448 \\
\hline 74 & 608 & 112 & 496 & 400 \\
\hline 75 & 856 & 170 & 683 & 491 \\
\hline 76 & 649 & 109 & 540 & 455 \\
\hline 77 & 1.458 & 205 & 1.253 & 1.069 \\
\hline 78 & 2.474 & 409 & 2.065 & 1.801 \\
\hline 79 & 3.368 & 563 & 2.805 & 2.454 \\
\hline 80 & 3.639 & 635 & 3.004 & 2.563 \\
\hline 81 & 4.124 & 810 & 3.314 & 2.752 \\
\hline 82 & 5.728 & 1.161 & 4.567 & 3.759 \\
\hline 83 & 7.639 & 1097 & 6.542 & 5.236 \\
\hline 84 & 8.945 & 1.540 & 7.405 & 5.835 \\
\hline 85 & 11.460 & 1.953 & 9.507 & 7.409 \\
\hline 86 & 10.167 & 2.139 & 8.028 & 5.989 \\
\hline 87 & 11.059 & 1.720 & 9.339 & 7.086 \\
\hline 88 & 11.296 & 1.689 & 9.607 & 7.457 \\
\hline 89 & 11.445 & 1.903 & 9.542 & 7.497 \\
\hline 90 & 11.344 & 1.740 & 9.604 & 7.666 \\
\hline 91 & 12.234 & 1.710 & 10.524 & 8.266 \\
\hline 92 & 11.339 & 1.614 & 9.725 & 7.662 \\
\hline 93 & 10.912 & 877 & 10.035 & 8.023 \\
\hline 94 & 12.315 & 1.526 & 10.789 & 8.430 \\
\hline 95 & 12.688 & 1.664 & 10.604 & 7.877 \\
\hline 96 & 13.903 & 2.137 & 11.766 & 8.732 \\
\hline 97 & 14.901 & 1.996 & 12.905 & 9.250 \\
\hline
\end{tabular}

Fonte: MIC-IAA até 1985 e AIAA-ESP após 1986.

* NOTA: FERNANDES, A.C. Desempenho da agroindústria da cana-de-açúcar no Brasil (1970-1997). Centro de Tecnologia Copersucar, Piracicaba. Comunicação Pessoal, 2000. 
A figura 9 mostra o significante aumento da área cultivada de canade-açúcar no Brasil e no Estado de São Paulo entre 1970 e 1985 e posteriormente, o contínuo aumento entre 1985 e 2000.

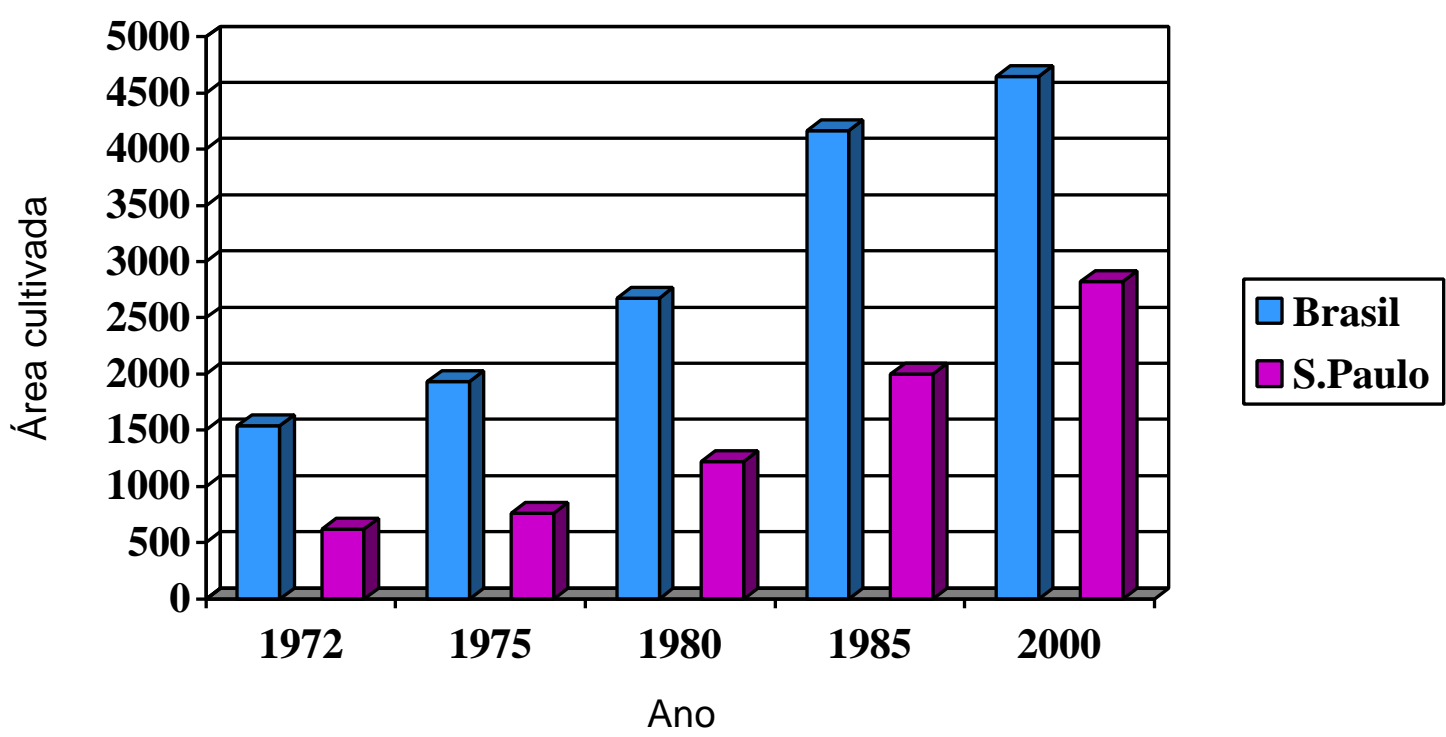

Figura 9. Área de cana-de-açúcar (milhares de hectares) cultivada no Brasil e no Estado de São Paulo (MINISTÉRIO DA AGRICULTURA, 2001).

A expansão da cultura de cana-de-açúcar abrangeu práticamente todo o território nacional, Dados obtidos no ano de 1996, mostram que somente cinco estados brasileiros não cultivavam a cana-de-açúcar (figura 10) . O maior produtor nacional de açúcar e de álcool é o Estado de São Paulo, que responde por sessenta e cinco por cento da produção (figura 10). A cultura da cana-de-açúcar é a principal cultura agrícola paulista e em 1997 ocupava a área de 1.118 .855 hectares o que correspondia a $46 \%$ da área agrícola total do estado, estimada pelo Instituto de Economia Agrícola em 2.446.308 hectares (figura 11). No ano de 1997 demandava 46,7\% da força de trabalho empregada na agropecuária paulista (BASALDI et al., 1998; ZANCUL, 1998; LIMA et al. 1999; MINISTÉRIO DA AGRICULTURA, 2001). 


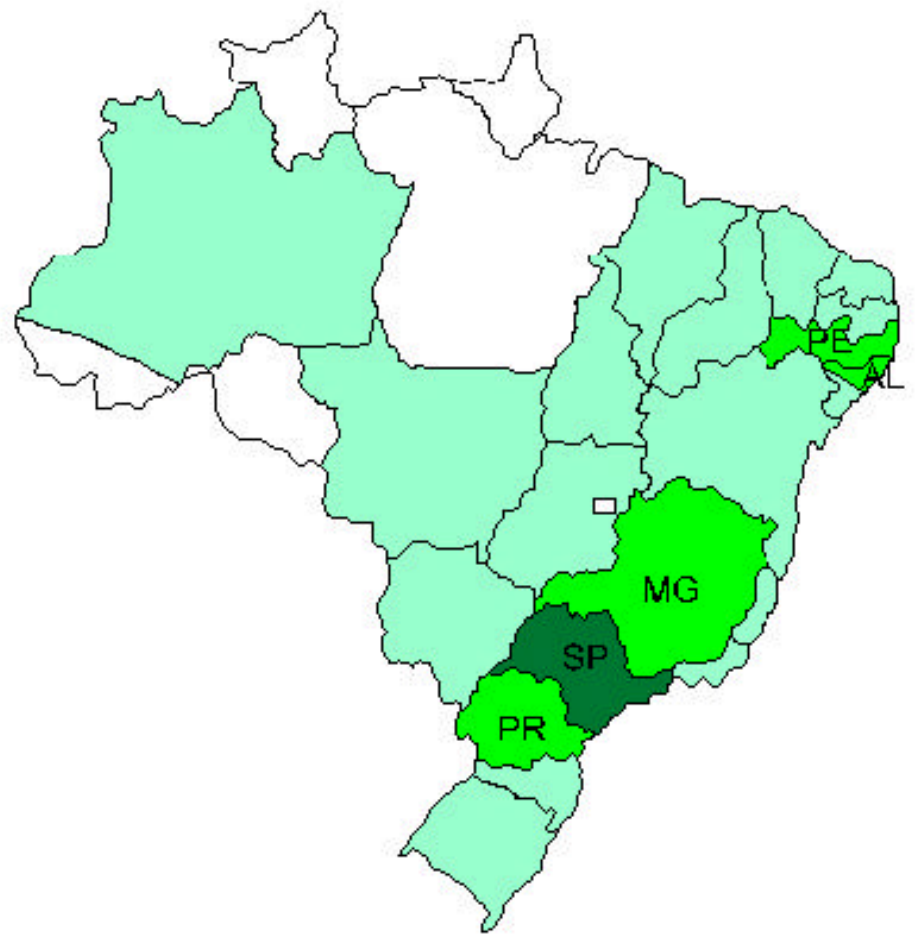

a) Estados produtores de cana-de-açúcar.

$(\%)$

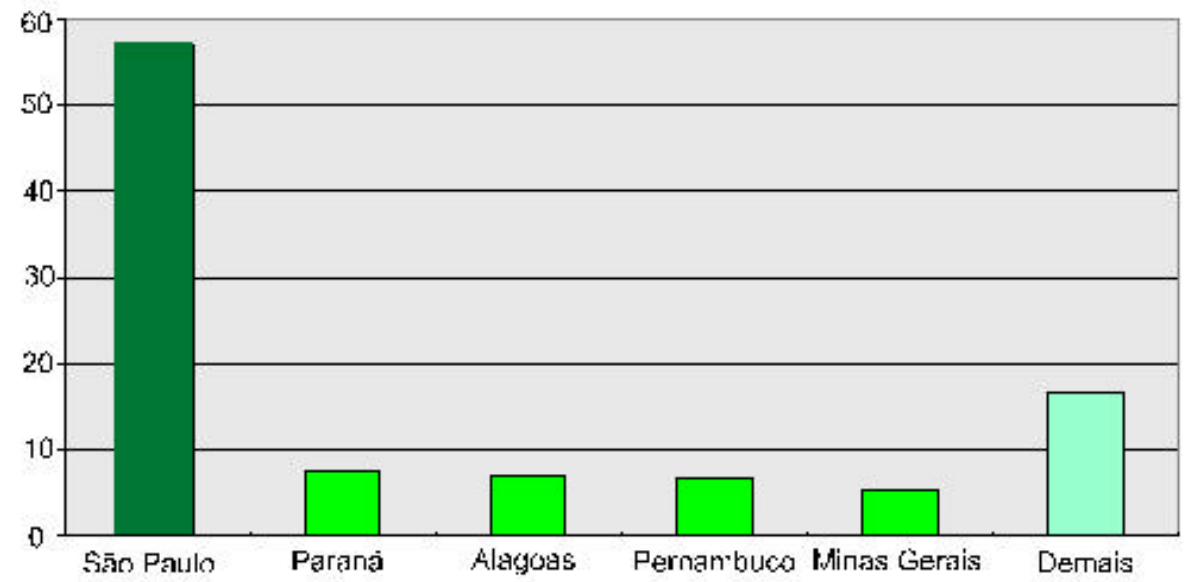

b) Distribuição da produção (\%) de cana-de-açúcar nos estados brasileiros.

Figura 10. Distribuição (\%) da produção de cana-de-açúcar nos estados brasileiros (LIMA, 1999). 


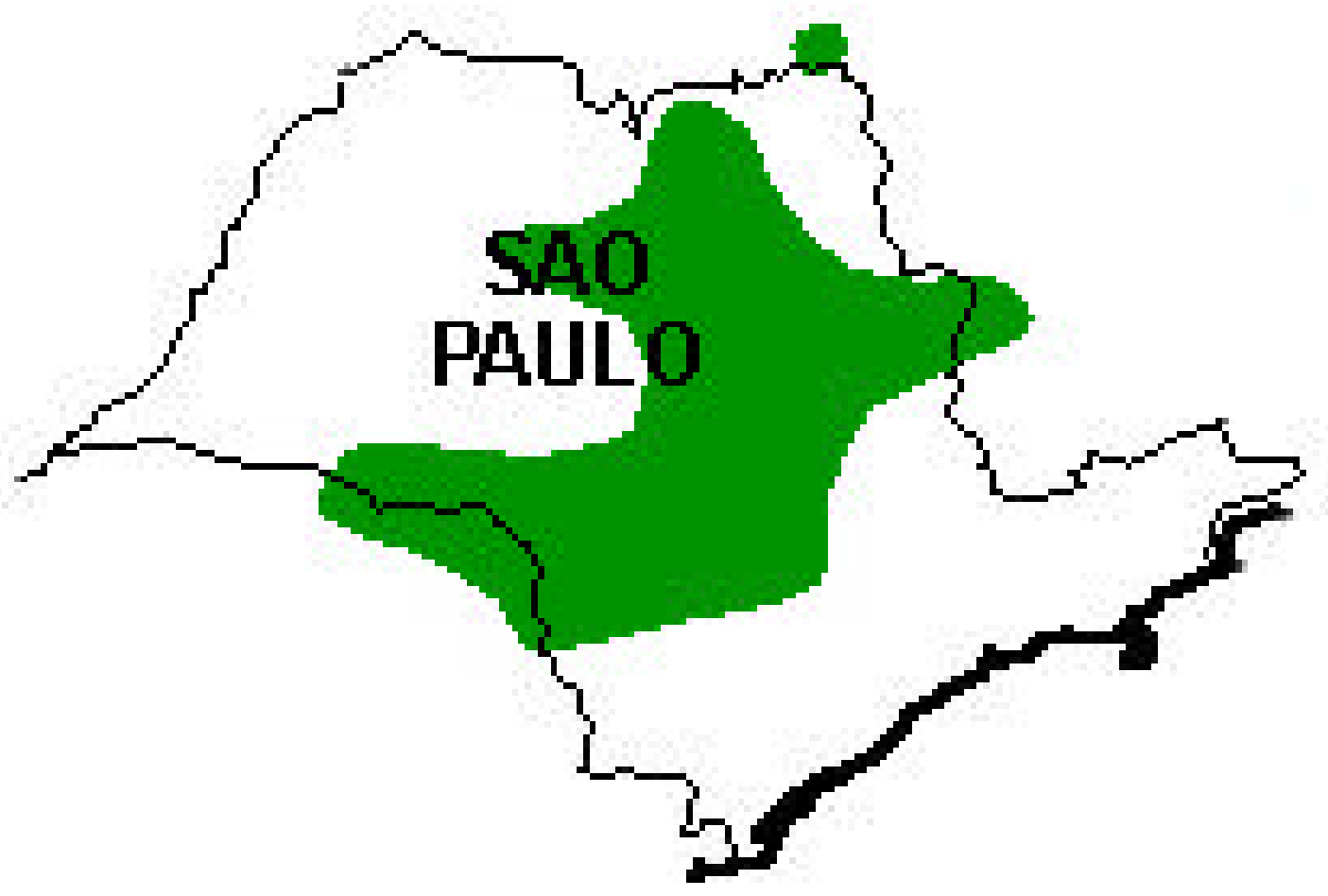

Figura 11. Área de cultivo de cana-de-açúcar (em verde) no Estado de São Paulo no ano de 1997 (USDA, 2001).

Analisando os dados, verificamos que a área utilizada para o cultivo da cana-de-açúcar aumentou substancialmente após a implantação do Proálcool, assim como a produção do álcool utilizado como combustível.

\subsubsection{A Queima da Cana-de-Açúcar}

Por razões de produtividade a cana-de-açúcar é queimada na précolheita.

O Brasil é o único produtor do mundo que realiza duas colheitas de cana-de-açúcar por ano: uma no Norte-Nordeste, de dezembro a maio, e 
outra na região Centro-Sul de abril a novembro (MARINHO; KIRCHHOFF, 1991). Porém, até há aproximadamente quarenta e cinco anos atrás, os canaviais brasileiros não eram queimados como prática usual na précolheita.

As razões para tal fato justificavam-se:

1. pela área cultivada relativamente pequena;

2. pelas baixas produtividades físicas da cultura;

3. pelas variedades plantadas, que, mais nobres, apresentavam despalha mais fácil;

4. pelos incipientes sistemas de transporte da matéria-prima;

5. pelos baixos padrões de eficiências indústriais existentes;

6. pela relativa disponibilidade de mão-de-obra para o corte;

7. pela falta de equipamentos para o carregamento

8. pela maior participação de entidade de classe de trabalhadores.

$\mathrm{Na}$ medida em que ocorreu um grande desenvolvimento tecnológico no setor sucroalcooleiro, aliado à expansão das áreas cultivadas, aumento na produtividade agrícola e na capacidade de produção da agroindústria, a prática de se atear fogo ao canavial antes da colheita tornou-se corriqueira, apesar de ser considerada uma prática agrícola anormal, uma vez que somente na cultura de cana é adotada. Seu principal objetivo é facilitar o corte, seja manual, seja mecanizado, com base nas seguintes justificativas: 
1. Diminuição do esforço físico despendido pelo trabalhador braçal, adequando-se melhor (mas ainda não o suficiente) ao seu baixo consumo de calorias ingeridas pela alimentação insuficiente.

2. Aumento da capacidade diária de corte, por parte do trabalhador, saltando de 1,5-2 t/dia para 7-12 t/dia, dependendo das características agronômicas do canavial, da compleição física do cortador braçal, de seu treinamento, do tipo de ferramenta utilizada e de seu conteúdo energético alimentar diário.

3. Redução drástica no número de acidentes ocupacionais (olhos, membros inferiores e superiores do corpo) referentes ao corte manual, com uso do facão.

4. Redução sensível no número de trabalhadores atacados por animais peçonhentos (cobras, escorpiões, aranhas), os quais são eliminados durante a queima.

5. Diminuição significativa da quantidade de matéria estranha vegetal (folhas, pontas, palhas, ervas daninhas) que acompanham os colmos cortados, carregados e transportados, com reflexos positivos na indústria.

6. Aumento na densidade de transporte da matéria prima, com reflexos na redução de custos da tonelada transportada/km rodado, e na quantidade de unidades de cada frota.

7. Diminuição do desgaste de moendas por operarem com matéria prima com menores teores de fibras, além do aumento no volume esmagado/unidade de tempo. E, mais, diminuição das perdas de sacarose na extração (CETESB, 1993). 
Conseqüentemente, a queima pré-colheita conduz a uma melhora na produtividade e na segurança do trabalhador braçal, além de se evitar que se elevem os custos com a produção do álcool e do açúcar.

Segundo a COPERSUCAR (1986), ao efetuar a queima da cana-deaçúcar na pré-colheita observa-se o estado vegetativo das plantas, a direção do vento e as condições meteorológicas. Estes aspectos são analisados de modo a evitar-se que a temperatura atingida seja muito alta, o que ocorre sob condições de canavial excessivamente seco, com baixa umidade atmosférica. Evitando-se queimar a cana no período diurno reduz-se o risco de o fogo escapar ao controle dos trabalhadores, bem como se ameniza o cozimento dos tecidos e açúcares próximos da casca, e as perdas devido à exsudação de água e açúcares. No dia seguinte, logo de manhã os cortadores já dispõem de área para trabalhar.

Segundo ZANCUL (1998), pesquisa realizada pela Comissão Técnica de Cana-de-açúcar da Secretaria de Agricultura do Estado de São Paulo junto aos associados da União da Agroindústria Canavieira do Estado de São Paulo mostrou o estágio do processo de colheita utilizado na safra $1997 / 1998$.

Com relação à modalidade de colheita:

- $81,8 \%$ da área plantada é queimada, e a colheita é manual.

- $11 \%$ da área plantada é queimada, e a colheita é mecânica. 
- $2,4 \%$ da área não é queimada, e a colheita é manual.

- $5 \%$ aproximadamente da área não é queimada, e a colheita é mecânica.

Os rendimentos máximos obtidos para as diversas modalidades resultaram em 12,5t/homem-dia para a colheita manual queimada; 6,5 t/homem-dia para colheita manual não queimada; 48t/hora-máquina para colheita queimada e mecanizada e 40t/hora-máquina para colheita mecânica não queimada

\subsubsection{Produtos Gerados pela Queima da Cana-de-açúcar}

Segundo NABAIS (1981) uma tonelada de cana queimada emite:

- 0.0005 tonelada de oxido de nitrogênio;

- 0,004 tonelada de material particulado;

- 0,006 tonelada de hidrocarbonetos;

- 0,028 tonelada de monóxido de carbono

As queimadas de cana emitem elementos particulados, aerossóis, gases como o dióxido de carbono e o monóxido de carbono, Durante as queimadas ocorre a liberação de gases precursores do ozônio, entre eles o já citado monóxido de carbono, o metano e hidrocarbonetos não metânicos. Sob a influência do descolamento das massas de ar, esses poluentes podem ser transportados para longe dos locais de produção, influenciando 
dessa maneira regiões distantes. Essa prática foi parcialmente interditada no Havaí, onde o turismo, representando a maior parte do rendimento do país, sofreu depreciação do valor, motivada pela deposição de material particulado nas orlas costeiras, muitas vezes situadas a mais de 20 quilômetros dos locais das queimadas.

MARINHO; KIRCHHOFF (1991) chamam a atenção para o fato de que a quantidade de matéria seca queimada nos canaviais por ano por unidade de área é cerca de 15 vezes maior que na Amazônia, isto é, tem-se $0,5 \mathrm{Kg} / \mathrm{m}^{2}$ nos canaviais, enquanto na Amazônia tem-se $0,03 \mathrm{Kg} / \mathrm{m}^{2}$. Além das partículas e aerossóis, as queimadas da cana emitem para a atmosfera uma grande quantidade de gases, entre eles, o dióxido de carbono $\left(\mathrm{CO}_{2}\right)$, principal gás do efeito estufa, e o monóxido de carbono (CO), além de gases precursores do ozônio $\left(\mathrm{O}_{3}\right)$. Os principais gases que geram ozônio, através da oxidação fotoquímica, são $\mathrm{CO}, \mathrm{CH}_{4}$, e hidrocarbonetos não metânicos (HCNM) na presença de $\mathrm{NO}$ e $\mathrm{NO}_{2}$. Ressalta-se que uma molécula de $\mathrm{CO}$ pode gerar uma molécula de ozônio, uma molécula de $\mathrm{CH}_{4}$ pode gerar 3,5 moléculas de ozônio e os hidrocarbonetos não metânico, 10 a 14 moléculas de ozônio. O aumento na concentração de monóxido de carbono e dióxido de carbono variou três a seis vezes durante as queimadas de cana-deaçúcar em relação a estação chuvosa quando a atmosfera está limpa devido a ocorrência de chuvas e pela ausência de queimadas. Deve-se ressaltar, entretanto, que a forte liberação de dióxido de carbono pela queima de palha de cana não contribui a médio e longo prazo para o efeito estufa, pois uma quantidade equivalente deste gás é retirada da atmosfera via fotossíntese durante o crescimento do canavial. 
JENKINS (1995) relata que estudando a emissão de fatores poluentes da queima de cana-de-açúcar em simulações produzidas em túnel de vento, encontrou $\mathrm{CO}, \mathrm{CO}_{2}, \mathrm{NO}, \mathrm{NO}, \mathrm{SO}_{2}, \mathrm{CH}_{4}$, hidrocarbonetos não metânicos, sulfatos e material particulado, além de compostos orgânicos voláteis (COV), e hidrocarbonetos policíclicos aromáticos (HPA). Quanto ao tamanho do material particulado constatou-se uma ampla variação incluindo $P M_{2,5} \mathrm{e}$ $\mathrm{PM}_{10}$.

A “USEPA" (1992) em mensurações realizadas na Lousiana, Flórida e Havaí estima o material particulado em 6-8,4lb/toneladas, o monóxido de carbono em 60-81 lb/ton, o metano em 1,2-3,8 lb/ton e os hidrocarbonetos não metânicos em 4-12 lb/ton.

LIMA et al., (1999) apresentam estimativas de emissão de gases de efeito estufa $\left(\mathrm{CH}_{4}, \mathrm{CO}, \mathrm{N}_{2} \mathrm{O}, \mathrm{NO}\right)$ provenientes da queima da cana-deaçúcar no Brasil, entre 1986 e 1996 (figuras, 12, 13, 14, 15). Em 1994, a emissão de gases provenientes da queima da cana-de-açúcar correspondeu ao seguinte percentual em relação a estimativas de queima de biomassa global:- $\mathrm{CH}_{4}(0,3 \%) ; \mathrm{CO}(0,9-0,4 \%) ; \mathrm{N}_{2} \mathrm{O}(0,8 \%)$, $\mathrm{NOx}(0,9 \%)$. A área colhida e a produtividade da cana-de-açúcar no Brasil aumentaram (13\% e 10\% respectivamente) entre 1990 e 1996, promovendo acréscimos de cerca de $15 \%$ nas emissões estimadas dos gases $\mathrm{CO}$ e $\mathrm{CH}_{4}$, e de $14 \%$ nas emissões de $\mathrm{N}_{2} \mathrm{O}$ e $\mathrm{NO}_{x}$. 


\section{Emissão de CO}

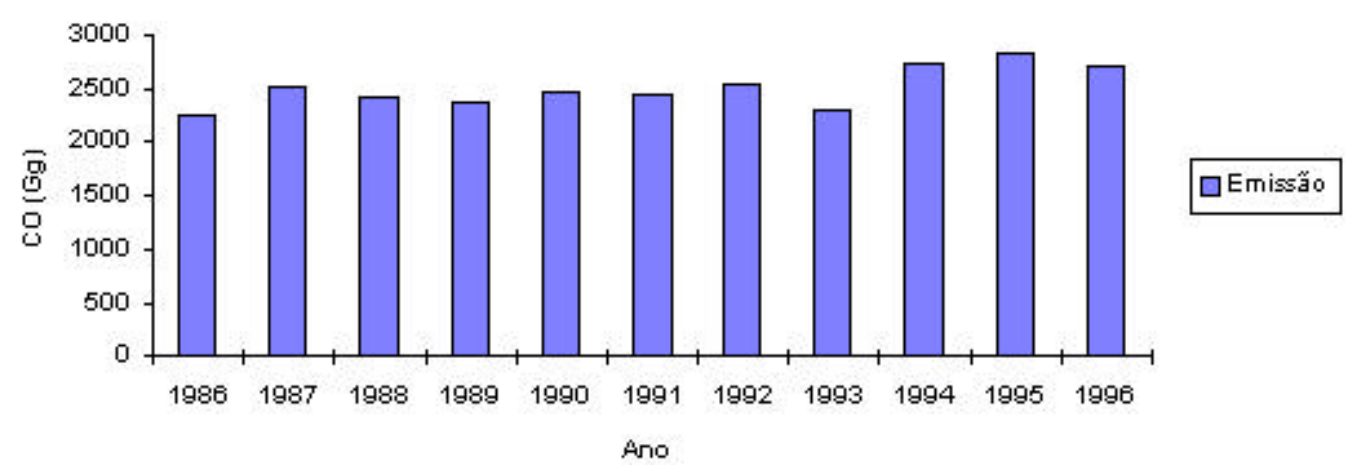

Figura 12. Evolução da emissão de monóxido de carbono proveniente da queima de cana-de-açúcar no Brasil entre 1985-1996 (LIMA et al., 1999).

Emissão de metano

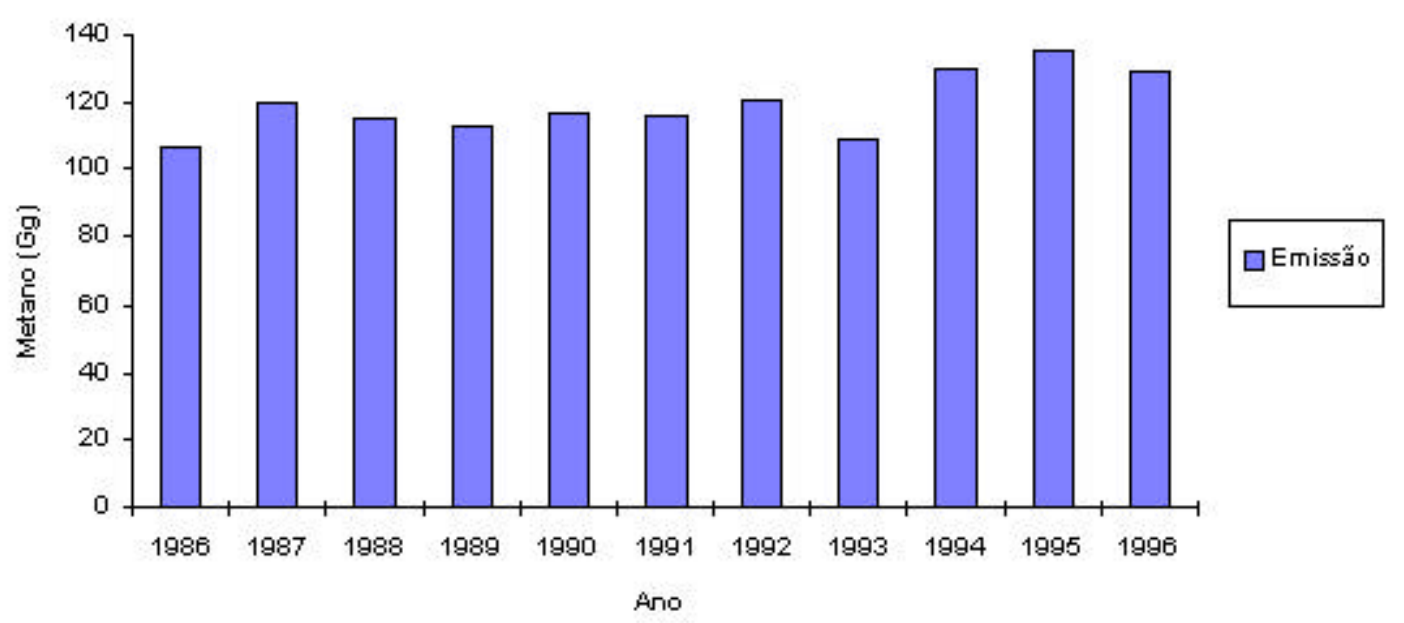

Figura 13. Evolução da emissão de metano proveniente da queima de canade-açúcar no Brasil entre 1985-1996 (LIMA et al., 1999). 


\section{Emissão de $\mathrm{N}_{2} \mathrm{O}$}

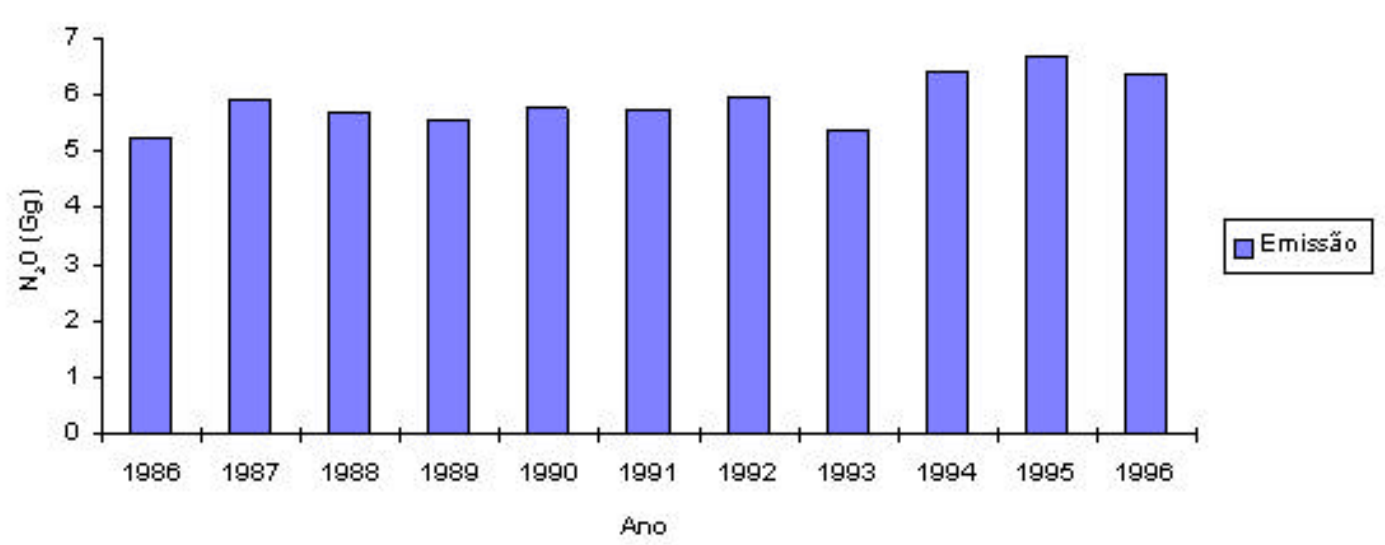

Figura 14. Evolução da emissão de dióxido de nitrogênio proveniente da queima de cana-de-açúcar no Brasil entre 1985-1996 (LIMA et al., 1999).

\section{Emissão de NOx}

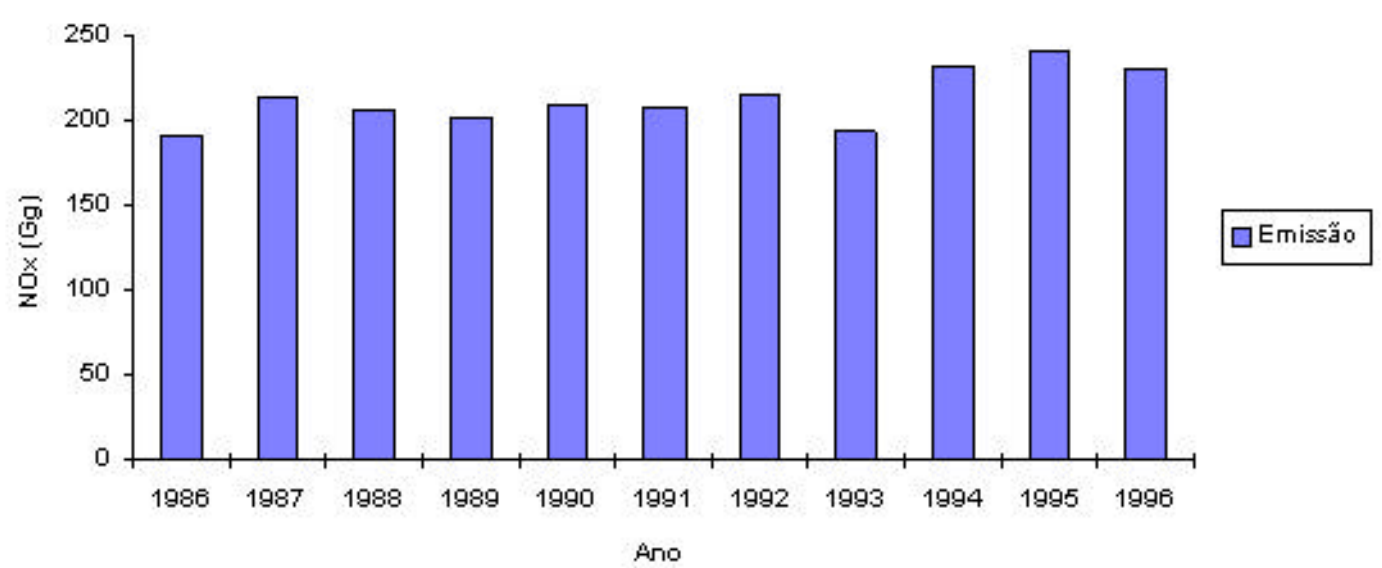

Figura 15. Evolução da emissão de óxido de nitrogênio proveniente da queima de cana-de-açúcar no Brasil entre 1985-1996 (LIMA et al., 1999). 
ZANCUL (1998) calculou aproximadamente a emissão de material particulado e de monóxido de carbono na atmosfera oriundos das queimadas que ocorrem no Estado de São Paulo. Foram utilizados os fatores de emissão da "USEPA" constantes do "Compilation of Air Pollutant Emission Factors, fourth edition, sept. 1985, vol l" :

Material Particulado - fator de emissão - 2,5- 3,5 kg/t

Monóxido de carbono - fator de emissão - 30,0 -41 kg/t

Considerando-se que no Estado de São Paulo se queimam por dia cerca de 81.516,68 toneladas de palha de cana-de-açúcar e utilizando-se os valores máximos fornecidos para os fatores de emissão, chega-se ao seguinte resultado:

Emissão de material particulado por dia:

$81.516,68 \times 3,5 \mathrm{~kg} / \mathrm{t}=285.308,38 \mathrm{~kg}=285$ toneladas

Emissão de monóxido de carbono por dia:

$81.516,68 \times 41 \mathrm{~kg} / \mathrm{t}=3 \cdot 342 \cdot 138,88 \mathrm{~kg}=3342$ toneladas

O autor compara os valores acima citados com os valores encontrados na região metropolitana de São Paulo para os parâmetros acima citados e constantes do Relatório Anual de Qualidade do $\operatorname{Ar}$ da CETESB (1996) para estimativa da emissão de material particulado e monóxido de carbono pelos veículos automotores (CETESB, 1997a):

Emissão de material particulado por dia - 62 toneladas

Emissão de monóxido de carbono por dia - 4293 toneladas. 
O autor considera que a área da região metropolitana de São Paulo é de cerca de $7.000 \mathrm{~km} 2$, ocupando $2,82 \%$ da área total do Estado de São Paulo, enquanto as queimadas das plantações de cana-de-açúcar ocorrem no interior do estado, em diversos municípios, em uma área de cerca de $20.739 \mathrm{~km}^{2}$, que representa aproximadamente $8,22 \%$ da área do estado.

\subsubsection{A Queima da Cana-de-Açúcar em Araraquara}

No ano de 1986, a CETESB realizou na cidade de Araraquara uma avaliação da qualidade do ar, com ênfase para a poeira total em suspensão, utilizando "amostrador de grandes volumes". Esse método consiste na aspiração do ar através de um filtro de fibra de vidro a uma alta vazão (cerca de $1,5 \mathrm{~m}^{3} / \mathrm{min}$ ), durante 24 horas. As partículas coletadas foram menores que $100 \mu$, e os dados gerados foram utilizados na comparação com os padrões legais, que para este caso, é de $240 \mu \mathrm{g} / \mathrm{m}^{3}$ (regulamento da lei $\mathrm{n}^{0}$ 997/76 Decreto 8468/76). As partículas retidas foram quantificadas gravimetricamente. As amostragens foram realizadas diariamente durante dois meses, sendo uma amostragem efetuada antes da safra (de 10/05/86 a 09/06/85), e outra, durante a safra (de 17/09/85 a 22/10/86). Os valores encontrados para a poeira total em suspensão encontram-se na tabela 9. 
Tabela 9. Dados coletados em Araraquara com amostrador de grandes volumes, para poeira total em suspensão (1985/1986) (CETESB, 1986).

\begin{tabular}{|l|c|c|c|c|}
\hline & $\mathbf{N}$ & $\mathbf{1}$ Máximo & 20 Máximo & M.G. \\
\hline Safra & 28 & $177 \mu \mathrm{g} / \mathrm{m}^{3}$ & $174 \mu \mathrm{g} / \mathrm{m}^{3}$ & $86 \mu \mathrm{g} / \mathrm{m}^{3}$ \\
\hline Entre-Safra & 30 & $77 \mu \mathrm{g} / \mathrm{m}^{3}$ & $74 \mu \mathrm{g} / \mathrm{m}^{3}$ & $39 \mu \mathrm{g} / \mathrm{m}^{3}$ \\
\hline
\end{tabular}

$\mathrm{N}$ = número de observações

$1^{\circ}$ Máximo $=$ Valor Maximo observado $\mu \mathrm{g} / \mathrm{m} 3$

$2^{\circ}$ Maximo $=2^{\circ}$. valor Maximo observado $\mu \mathrm{g} / \mathrm{m} 3$

$\mathrm{m} . \mathrm{g} .=$ média geométrica $\mu \mathrm{g} / \mathrm{m} 3$

Verifica-se que apesar de não ter sido ultrapassado o padrão (240 $\mu \mathrm{g} / \mathrm{m}^{3}$ ), o valor máximo atingido pela poeira total em suspensão durante a safra é substancialmente mais elevado do que durante a entressafra. A média geométrica acompanha essa tendência.

Entre 02/09 e 20/10/97(período da safra), e nos meses de abril e maio de 1998 (período da entressafra), a CETESB efetuou nova avaliação da qualidade do ar em Araraquara, utilizando uma estação móvel telemétrica, equipada com equipamentos automáticos. Todos os parâmetros, tanto da qualidade do ar quanto metereológicos, foram avaliados de forma contínua, armazenados, e enviados diariamente, via linha telefônica, à cidade de São Paulo, onde foram validados e processados. A CETESB, nesse período, fez a medição dos seguintes poluentes:- Material Particulado, Dióxido de Enxofre, Monóxido de Carbono, Dióxido de Nitrogênio, Ozônio. A tabela 10 mostra os métodos adotados para medição dos diferentes poluentes. A tabela 11 mostra o material particulado significativamente mais elevado durante o período da safra, em relação ao período da entressafra. Observamos, outrossim, que durante o período da safra o ozônio ultrapassou o padrão por quatro vezes. 
Tabela 10. Método de medição dos poluentes em Araraquara nos anos de 1997/1998 (CETESB, 1997b).

\begin{tabular}{|l|l|}
\hline \multicolumn{1}{|c|}{ Poluente } & \multicolumn{1}{c|}{ Método de Medição } \\
\hline Partículas Inaláveis $(\mathrm{PI})$ & Absorção de Radiação b \\
\hline Dióxido de Enxofre $\left(\mathrm{SO}_{2}\right)$ & Fluorescência \\
\hline Monóxido de Carbono $(\mathrm{CO})$ & Infravermelho não-dispersivo \\
\hline Dióxido de Nitrogênio $\left(\mathrm{NO}_{2}\right)$ & Quimiluminescência \\
\hline Ozônio $\left(\mathrm{O}_{3}\right)$ & Fotométrico com radiação ultravioleta \\
\hline
\end{tabular}

Tabela 11. Avaliação da qualidade do ar e quantificação dos poluentes em Araraquara nos anos 1997/1998 (CETESB, 1999).

POLUENTES:

\begin{tabular}{|c|c|c|c|}
\hline & SAFRA & $\begin{array}{l}\text { ENTRE - } \\
\text { SAFRA }\end{array}$ & PADRÂO \\
\hline Partículas inaláveis $\left(\mu \mathrm{g} / \mathrm{m}^{3}\right)$ & $\begin{array}{l}52 \\
\operatorname{mín}-17 \\
\max -117\end{array}$ & $\begin{array}{c}38 \\
\text { mín }-13 \\
\max -69\end{array}$ & $\begin{array}{l}\text { 50/MAA } \\
150 / 24 \mathrm{~h}\end{array}$ \\
\hline Dióxido de Enxofre $\left(\mu \mathrm{g} / \mathrm{m}^{3}\right)$ & $\begin{array}{c}8 \\
\text { mín }-1 \\
\max -27\end{array}$ & $\begin{array}{c}10 \\
\text { mín - } 1 \\
\max -52 \\
\end{array}$ & $\begin{array}{l}80 \text { MAA } \\
365 / 24 h \\
\end{array}$ \\
\hline Monóxido de Carbono (ppm) & $\begin{array}{l}\text { Mín - 0,8 } \\
\text { Max - 3,6 }\end{array}$ & $\begin{array}{l}\text { Mín } 0,4 \\
\text { Máx 2,5 }\end{array}$ & $9 / 8 \mathrm{~h}$ \\
\hline Dióxido de nitrogênio $\left(\mu \mathrm{g} / \mathrm{m}^{3}\right)$ & $\begin{array}{c}\text { Mín - } 20 \\
\text { Max - } 134\end{array}$ & $\begin{array}{c}\text { Mín - } 6 \\
\text { Máx - } 97\end{array}$ & $320 / 1 \mathrm{~h}$ \\
\hline $\begin{array}{l}\text { Ozônio* }\left(\mu \mathrm{g} / \mathrm{m}_{3}\right) \\
\bullet \quad 4 \text { ultrapassagens do } \\
\text { padrão }\end{array}$ & $\begin{array}{c}\text { Min }-61 \\
\operatorname{Max}-181\end{array}$ & $\begin{array}{l}\text { Mín - } 28 \\
\text { Max -102 }\end{array}$ & $160 / 1 \mathrm{~h}$ \\
\hline
\end{tabular}


Prosseguindo o estudo, a CETESB realizou medições do material carbonáceo orgânico e elementar durante a safra e durante a entressafra e comparou com o material carbonáceo quantificado em duas estações medidoras da região metropolitana de São Paulo (tabela 12).

Tabela 12. Comparação entre a quantidade de material carbonáceo em Araraquara e em duas estações medidoras da região metropolitana de São Paulo (CETESB, 1999).

ARARAQUARA

SÃO PAULO

\begin{tabular}{|l|l|l|l|l|}
\hline & Safra & $\begin{array}{c}\text { Entre } \\
\text { Safra }\end{array}$ & $\begin{array}{c}\text { Cerqueira } \\
\text { César }\end{array}$ & Ibirapuera \\
\hline Carbono Orgânico $\left(\mu \mathrm{g} / \mathrm{m}^{3}\right)$ & $20(32 \%)$ & $10(33 \%)$ & $20(29 \%)$ & $14(30 \%)$ \\
\hline Carbono Elementar $\left(\mu \mathrm{g} / \mathrm{m}^{3}\right)$ & $07(12 \%)$ & $05(15 \%)$ & $14(21 \%)$ & $04(09 \%)$ \\
\hline
\end{tabular}

A análise dos dados mostra que a quantidade de carbono orgânico medido em Araraquara durante o período da safra é comparável ao da estação Cerqueira César e superior ao verificado na entressafra em Araraquara e ao observado na estação medidora do Ibirapuera em São Paulo. A quantidade de carbono elementar medido durante a safra em Araraquara é menor do que a quantidade medida na estação Cerqueira César, e maior que a quantidade medida na entressafra em Araraquara e na estação Ibirapuera em São Paulo. 
Franco (2001) coletou amostras do material particulado em Araraquara durante a época de queima da cana e durante a época sem queima entre dezembro e abril utilizando o Impactador de Moudi. Observando-se a cor e a quantidade de material particulado retido nos filtros durante a época sem queimadas, compreendida entre dezembro e abril, e comparando-se à quantidade de material particulado na época das queimadas, os filtros da época da queimada apresentavam sempre uma quantidade grande de pó negro.

O material particulado durante a época das queimadas mostrou-se rico em partículas carbonáceas, principalmente com diâmetros finos e ultrafinos, como mostra a tabela 13 e figura 16.

Tabela 13. Coloração dos filtros do Impactador de Moudi após a coleta da "fuligem da cana" durante 48 horas (FRANCO 2001).

\begin{tabular}{|c|c|c|}
\hline Estagio & $\begin{array}{c}\text { Tamanho do orifício de entradas } \\
\text { das partículas(nm) }\end{array}$ & Coloração \\
\hline 01 & - & branco \\
\hline 02 & 18 & Cinza \\
\hline 03 & 10 & Marrom \\
\hline 04 & 5,6 & Cinza \\
\hline 05 & 3,2 & Preto \\
\hline 06 & 1,8 & Preto \\
\hline 07 & 1,0 & Preto \\
\hline 08 & 0,56 & Preto \\
\hline 09 & 0,32 & Branco \\
\hline 10 & 0,10 & Preto \\
\hline 11 & 0,18 & Preto \\
\hline 12 & 0,056 & \\
\hline
\end{tabular}


Estágios 10-12

$=0,056 \mu \mathrm{m}$

Estágios 07-09 $0,32-0,1 \mu \mathrm{m}$

Estágios $04-06$ $1,8-0,56 \mu \mathrm{m}$

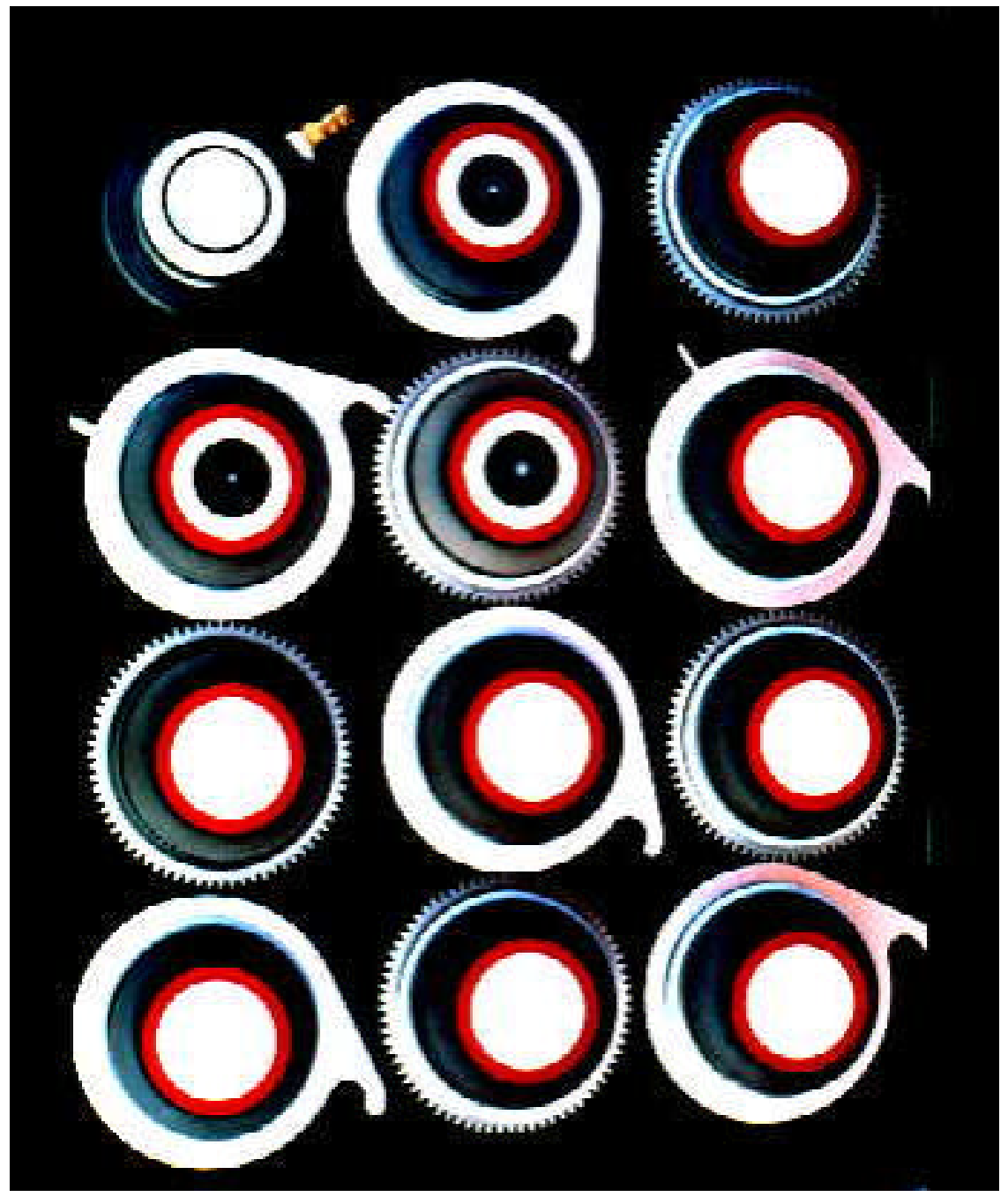

Figura 16. Fuligem proveniente da queima da cana-de-açúcar retida em diferentes tamanhos de filtros do Impactador de Moudi (FRANCO, 2001).

\subsubsection{Repercussão da Queima de Cana-de-açúcar}

Quando a cana é queimada na pré-colheita ocorre a produção de grande quantidade de fumaça, dependendo das condições atmosféricas e do estado vegetativo das plantas. Sob clima quente e seco, o canavial apresenta grande volume de folhas secas, e o fogo é extremamente rápido e intenso, gerando uma grande quantidade de elemento particulado negro denominado pela população das cidades circundadas pelos canaviais como "fuligem da cana" (figura 17, 18, 19). 


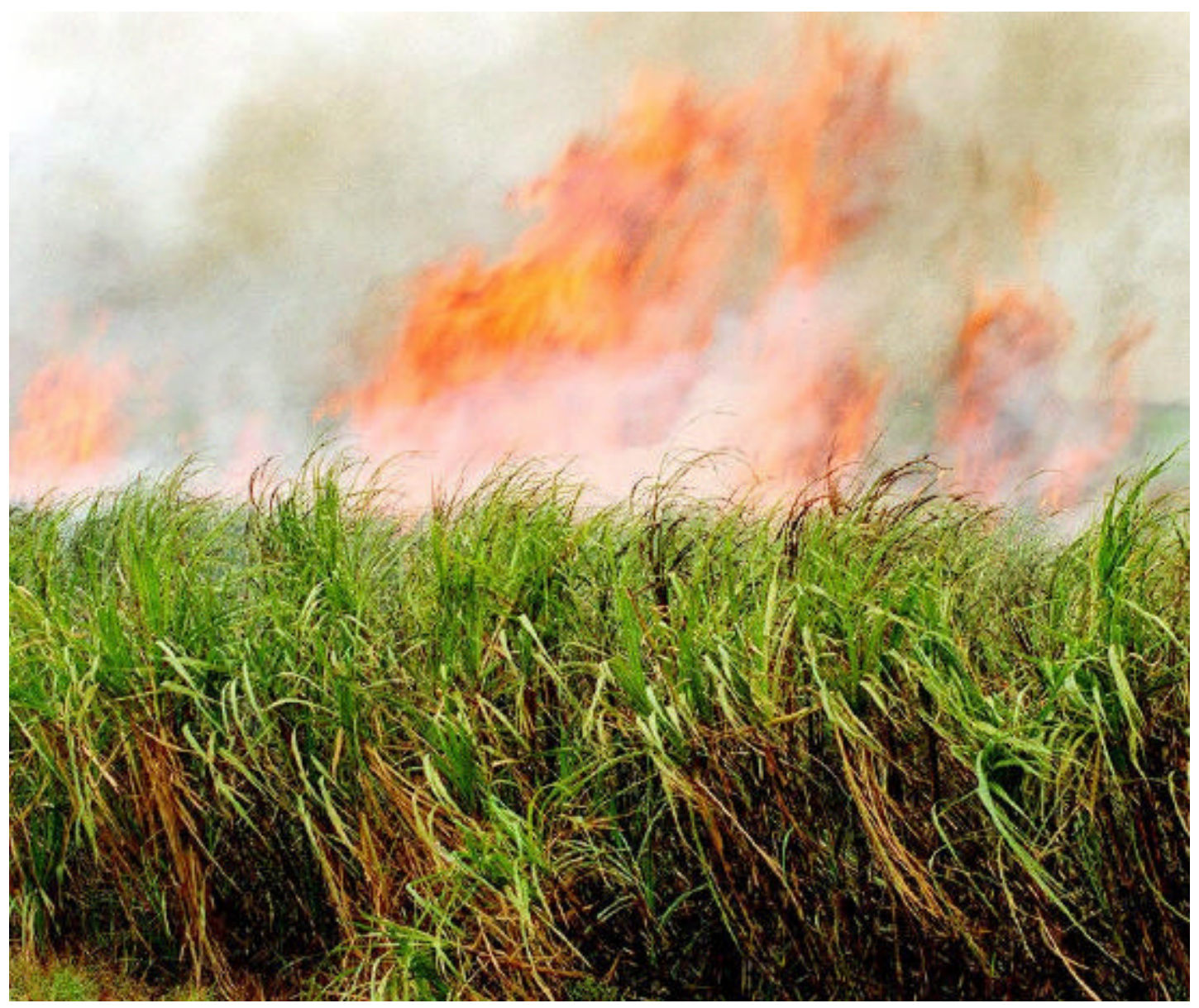

Figura 17. Queima no canavial

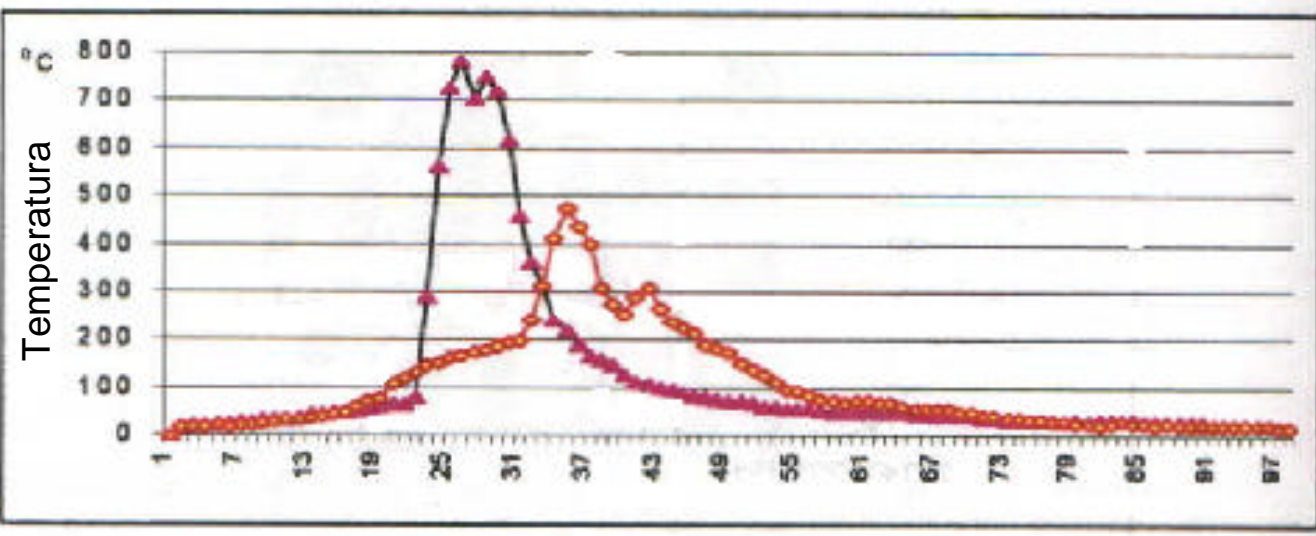

Tempo(segundos)

A Temperatura no canavial; Temperatura no caule da cana.

Figura 18. Curvas das variações das temperaturas durante a queima da cana-de-açúcar da cana (RIPOLI; RIPOLI, 2001). 


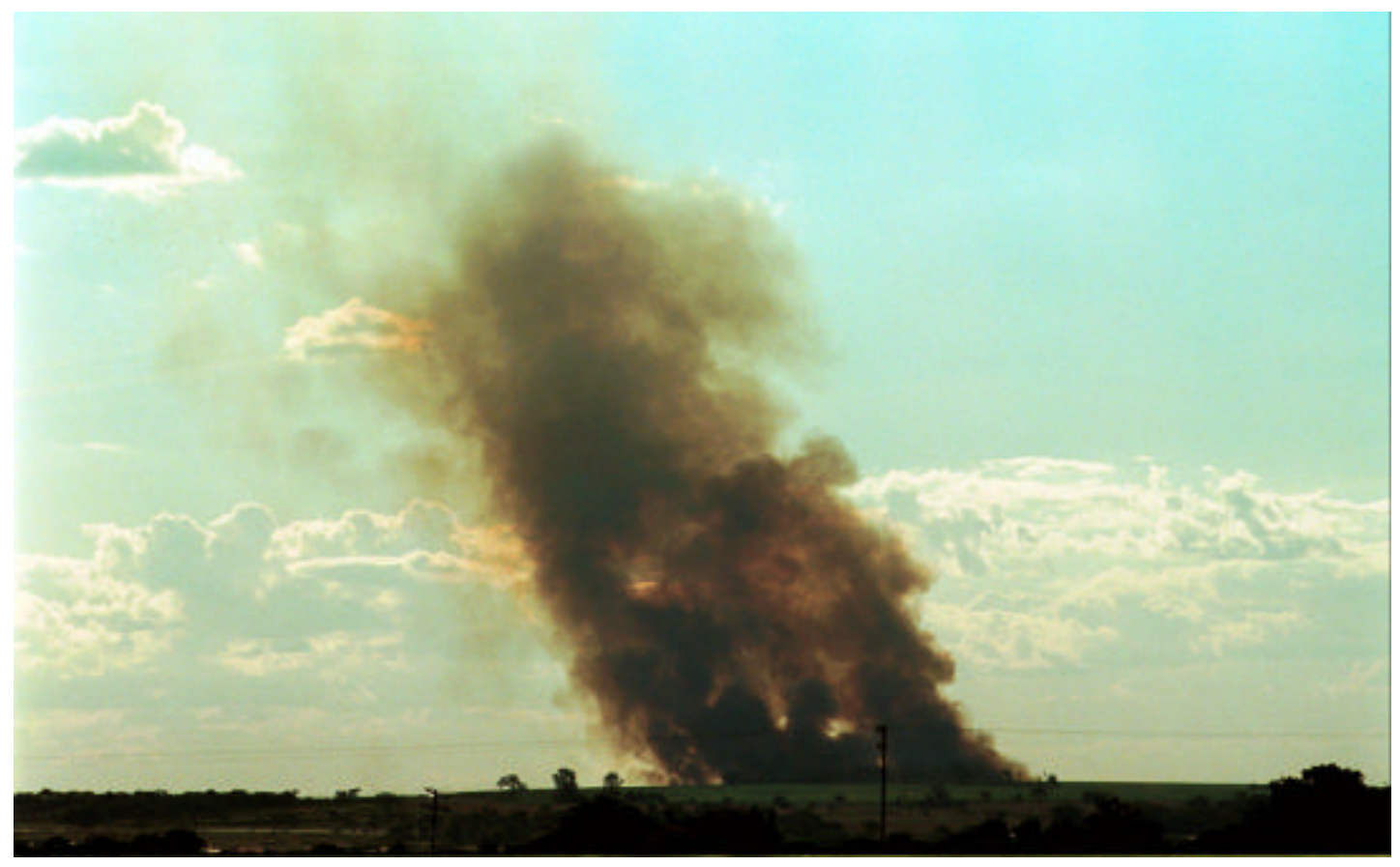

Figura 19. Fumaça e fuligem proveniente da queima da cana-de-açúcar

A indagação mais constante e mais freqüente é se a fuligem que cai sobre as cidades e sobre seus habitantes pode ter alguma interferência na qualidade de vida ou na saúde da população. Essa é uma questão que tem sido exaustivamente formulada a todos os profissionais, das mais variadas especialidades, que militam na área da saúde e na área do saneamento ambiental.

Do ponto de vista médico, o interesse pelo problema reside no fato de que muitos pacientes com doenças crônicas do aparelho respiratório, principalmente bronquite crônica, enfisema e asma, referem agravamento dos seus sintomas no período do ano que coincide com a queimada da 
cana. Mas não é só. Indivíduos hígidos, na mesma época do ano, referem com freqüência irritação em vias aéreas superiores, com ardor no nariz e na garganta. A presença na atmosfera de resíduos grosseiros resultantes da combustão da cana aparece, para a população em geral, como a evidência marcante de que os sintomas respiratórios dependem da poluição ambiental gerada pelas queimadas, ou são agravadas por ela.

Entretanto, o problema não é tão simples quanto aparenta. Não se pode, por exemplo, descartar a possibilidade de que alterações climáticas sejam as responsáveis pelo agravamento dos sintomas respiratórios em uma parcela de indivíduos da população.

FRANCO (1992 $\left.{ }^{*}\right)$ formulou algumas hipóteses:

1) Durante a época das queimadas dos canaviais há uma piora na qualidade do ar na região.

2) A queimada dos canaviais não é o único fator de agravamento da qualidade do ar, mas em conseqüência da extensão da área plantada e do tempo das queimadas (final de abril a início de novembro), as descargas de gases e de outros poluentes na atmosfera da região ganha um significado muito marcante e que não pode ser menosprezado.

3) A população de risco, que tem sua qualidade de vida e de saúde agravada em condições atmosféricas adversas, é bastante significativa.

NOTA: FRANCO, A.R. (Faculdade de Medicina de Ribeirão Preto, USP). Aspectos epidemiológicos da queimada de canaviais na região de Ribeirão Preto. Palestra proferida no Centro de Estudos Brasileiros, Ribeirão Preto, 31/03/1992. 
4) A maioria das pessoas que compõem essa população de risco demanda um número muito maior de consultas, de atendimentos ambulatoriais, de medicação e de internações. Tudo isso traduz um ônus muito grande de assistência médica, que atinge não só os serviços médicos, mas a economia das famílias.

Avaliar os efeitos sobre a saúde produzidos pela poluição do ar gerada por queimadas em vegetação a céu aberto é uma tarefa difícil. Fatores críticos para esta tarefa incluem características dos poluentes, população exposta, exposição individual, suscetibilidade do individuo exposto, fatores potencialmente confundidores e a intensidade e a gravidade dos efeitos sobre a saúde a serem estudados. Os dados disponíveis para esses fatores afetam substancialmente o tipo de estudo a ser escolhido. (WHO, 1999).

A Organização Mundial de Saúde (1999) estratifica a população sujeita a poluição atmosférica decorrente da queima de vegetação a céu aberto, de acordo com os efeitos produzidos sobre a saúde. O tamanho de cada nível na pirâmide representa a proporção da população afetada (figura 20). 


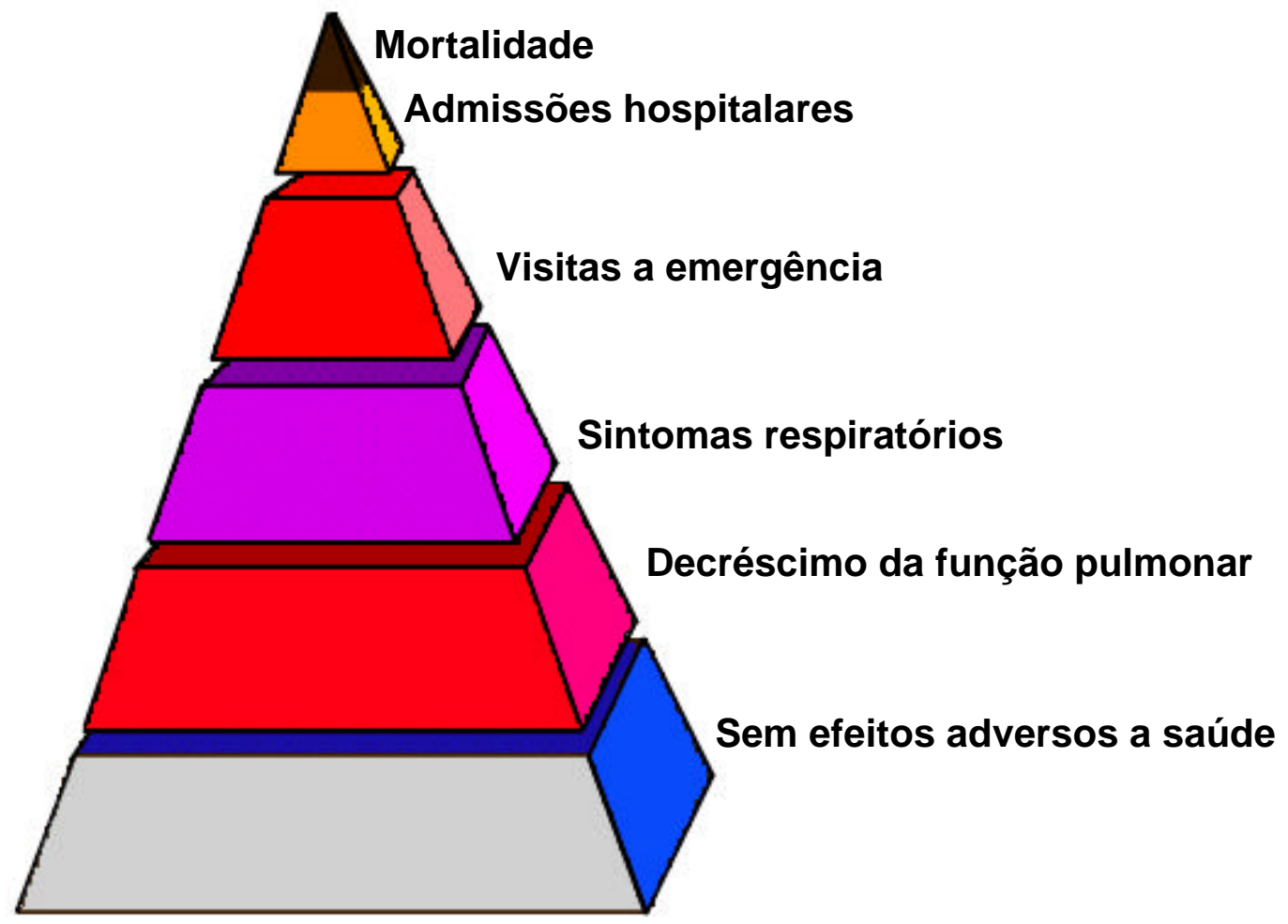

Figura 20. Proporcionalidade dos efeitos adversos à saúde atribuíveis a população em geral decorrente dos poluentes emitidos pela queima de vegetação (WHO, 1999).

Um percentual pequeno da população atingida terá um desenlace grave, como a mortalidade, enquanto sintomas menos graves como, por exemplo, a diminuição da capacidade pulmonar, atingirá proporcionalmente uma maior parcela da população.

Muitas são as regiões do Brasil e do planeta que enfrentam o problema das queimadas das culturas de cana-de-açúcar na pré-colheita. 
Essas regiões são laboratórios naturais onde a exposição da população aos poluentes provenientes da queima da biomassa se dá de modo programado. Entretanto, não há na literatura, trabalho técnico ou cientifico abordando o problema da queima de cana-de-açúcar e suas conseqüências sobre a saúde humana.

Portanto, já tarda a disposição de pesquisadores para se debruçarem sobre problema de tamanha relevância em termos de saúde pública.

Com o objetivo de preencher essa lacuna desenvolvemos um estudo epidemiológico na cidade de Araraquara, um laboratório natural para avaliar os efeitos dos poluentes decorrentes da queima de vegetação sobre a saúde dos habitantes. 
2. OBJETIVOS 
Este estudo foi idealizado com os objetivos relacionados a seguir.

\subsection{Geral}

Estimar os efeitos do material particulado proveniente da queima da cultura da cana-de-açúcar sobre a morbidade respiratória da população de Araraquara.

\subsection{Especifico}

2.2.1. Desenvolver um método simples, eficiente e de baixo custo para avaliar a deposição diária do material particulado sobre a cidade de Araraquara.

2.2.2. Verificar a eventual associação entre as medidas de poluição e um indicador de morbidade respiratória - o número diário de inalações no Serviço de Emergência em um dos principais hospitais de Araraquara.

2.2.3. Estimar o tipo de relação entre exposição e doença. 
3. MATERIAIS E MÉTODO 


\subsection{Tipo de Estudo}

Para a estimativa dos efeitos do material particulado gerado a partir da queima da cana-de-açúcar sobre a saúde da população de Araraquara foi proposto um estudo epidemiológico ecológico de séries temporais.

A epidemiologia ambiental evoluiu de forma marcante desde os primeiros estudos que avaliaram a relação entre os níveis dos poluentes no ar e os agravos à saúde dos seres humanos, realizados nas primeiras décadas do século passado. Nos dias de hoje, com o desenvolvimento cada vez maior da bioestatística e das técnicas de análise de dados em função do avanço dos programas de informática, têm sido detectados efeitos mesmo em áreas com baixas concentrações de poluentes. Dois tipos de estudos têm sido mais comumente utilizados nessa área: os estudos ecológicos de séries temporais, para investigar efeitos agudos, e os estudos de coorte para detectar efeitos crônicos (POPE; SCHWARTZ, 1996).

Os estudos ecológicos apresentam como principal característica a utilização de dados agregados em lugar de dados coletados em nível individual, isto é, são estudadas áreas geograficamente definidas, como uma cidade, um estado, uma região ou, até mesmo, um país. 
Os estudos ecológicos de séries temporais são particularmente eficientes para a detecção de efeitos agudos da poluição do ar. Com essa abordagem, é possível estudar a variação do número de ocorrências de um evento (mortes, internações hospitalares, visitas ao serviço de emergência), ao longo do tempo, como uma função de termos controladores para variações sazonais de diferentes freqüências (estações do ano, meses, dias), indicadores de temperatura e/ou umidade relativa do ar, ou outros fatores de interesse, entre eles, os níveis de poluição do ar (SALDIVA, 1998). A série temporal é mais comumente utilizada para intervalos de tempo de um dia, apesar de não haver obrigatoriedade de se manter esse intervalo.

O estudo ecológico de séries temporais, baseado na experiência anterior do Laboratório de Poluição Atmosférica Experimental (LPAE) do Departamento de Patologia da Faculdade de Medicina da Universidade de São Paulo, foi considerado o mais adequado ao experimento (SALDIVA et al, 1994; SALDIVA et al, 1995; EL KHOURI MIRAGLIA, 1997; LIN, 1997; BRAGA, 1998; FARHAT, 1999; PEREIRA, 1999).

\subsection{Localização de Araraquara no Estado de São Paulo}

Araraquara é considerada uma cidade de porte médio, com uma população de 172.921 habitantes (IBGE, censo em 01/08/1996), localizada na região central do Estado de São Paulo, latitude $21^{\circ} 47^{`} 31^{\prime}$ 'Sul, longitude $48^{\circ} 10^{`} 52^{\prime}$ Oeste. Dista da capital 273 quilômetros, e encontra-se a 30 
quilômetros do centro geográfico do Estado de São Paulo (figura 21). A altitude é de 646 metros. A área do município é de 1.063 quilômetros quadrados. Dados de 1997 mostravam uma renda per capita de US\$ 5.500/aa. O PIB era de $R \$ 3.200 .000 .000,00$ e a arrecadação municipal de R\$ 70.179.921,00. (PREFEITURA MUNICIPAL DE ARARAQUARA, 2000).

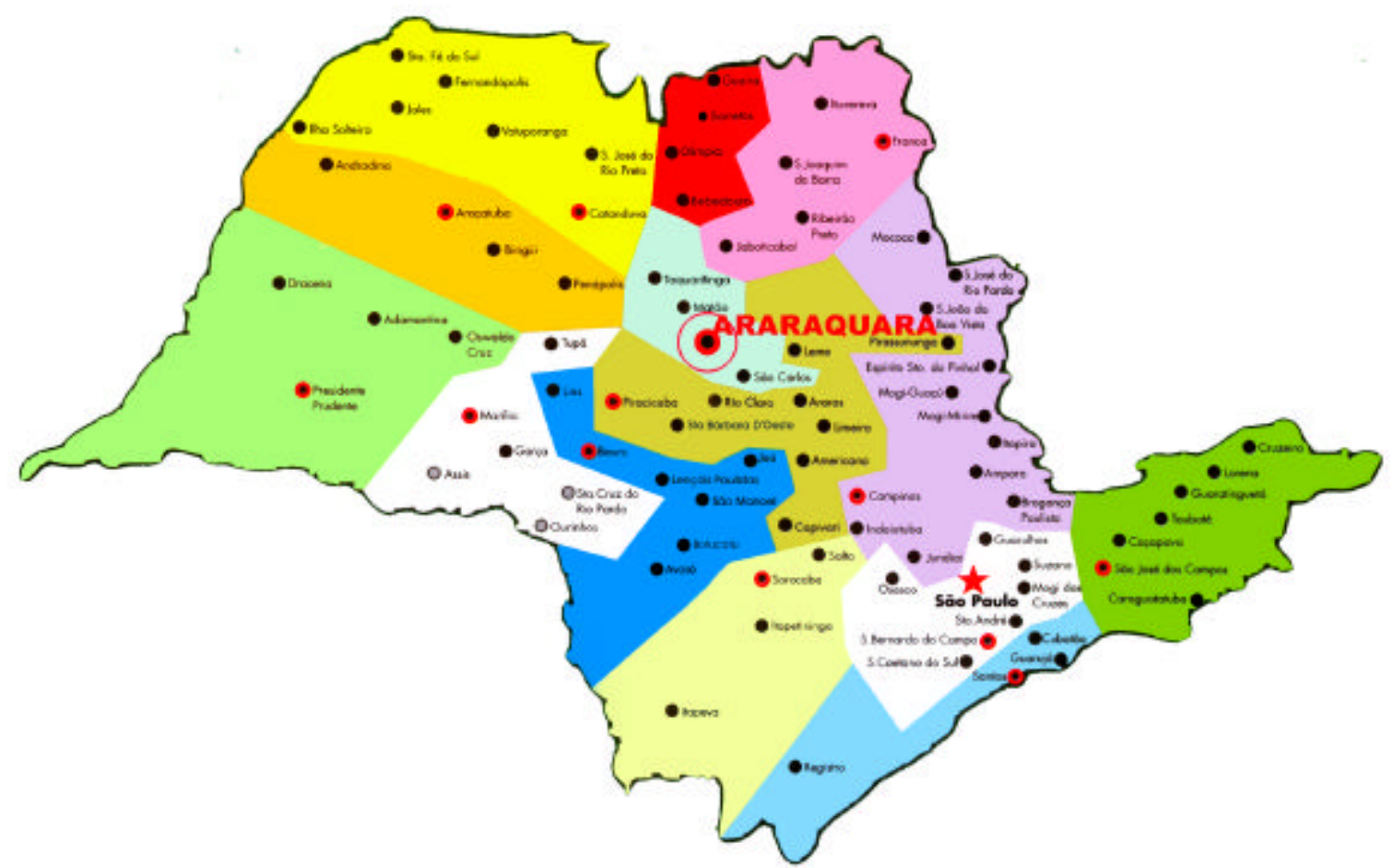

Figura 21. Localização de Araraquara no Estado de São Paulo.

Araraquara possui uma intensa atividade ligada à agroindústria sucroalcooeleira, com quinze usinas de açúcar e álcool no raio de oitenta quilômetros. Esse conjunto de empresas processa aproximadamente vinte e cinco milhões de toneladas de cana. A cidade de Araraquara é circundada por uma área de plantio da cana-de-açúcar de 500.000 hectares, com uma safra anual de 2.400.000 toneladas. A região canavieira de Araraquara (figura 22), é responsável pela produção de aproximadamente 9 a $10 \%$ do total da canade-açúcar produzida no Estado de São Paulo (figura 23) (ÚNICA, 2001). 


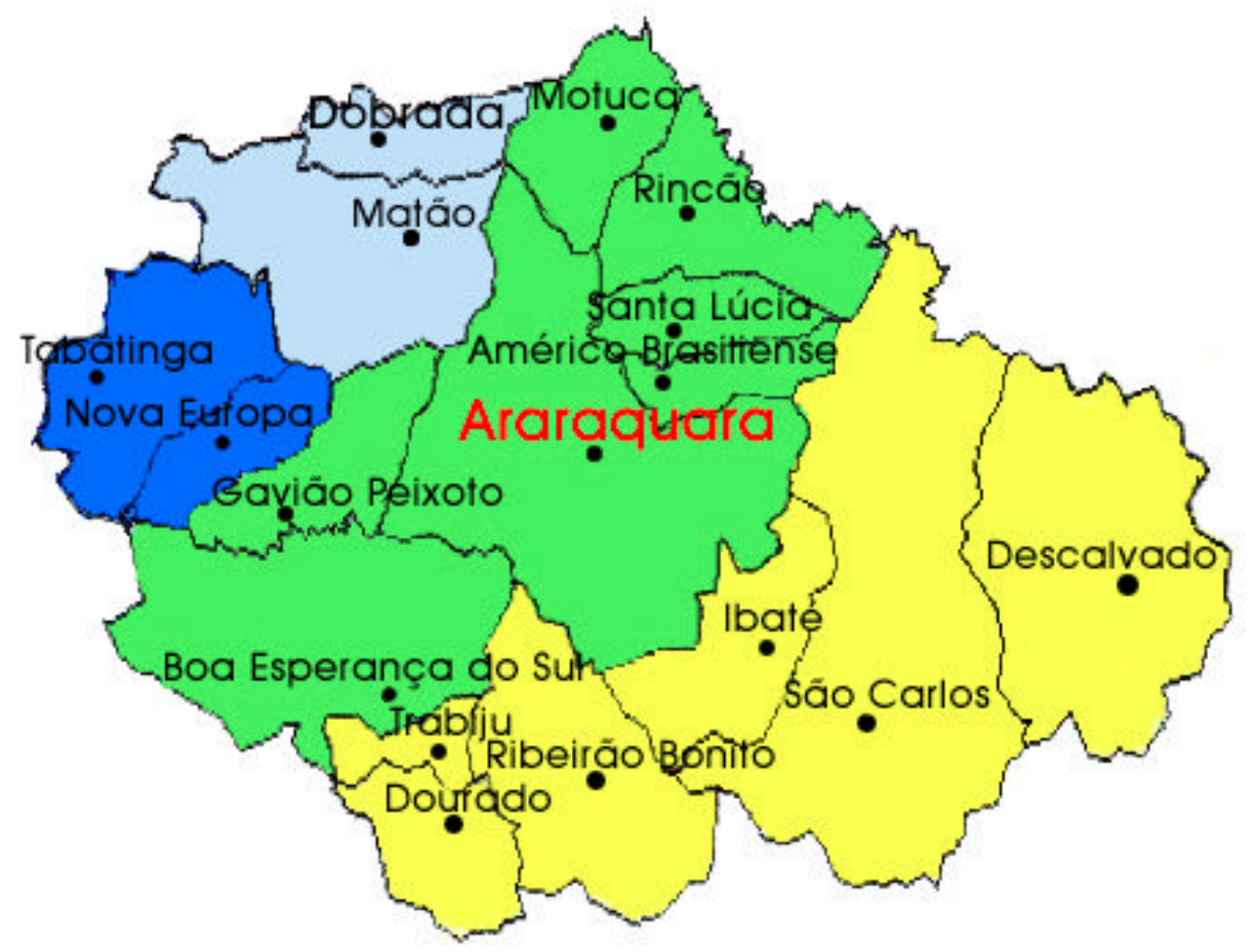

Figura 22. Região canavieira de Araraquara (ÚNICA, 2001).

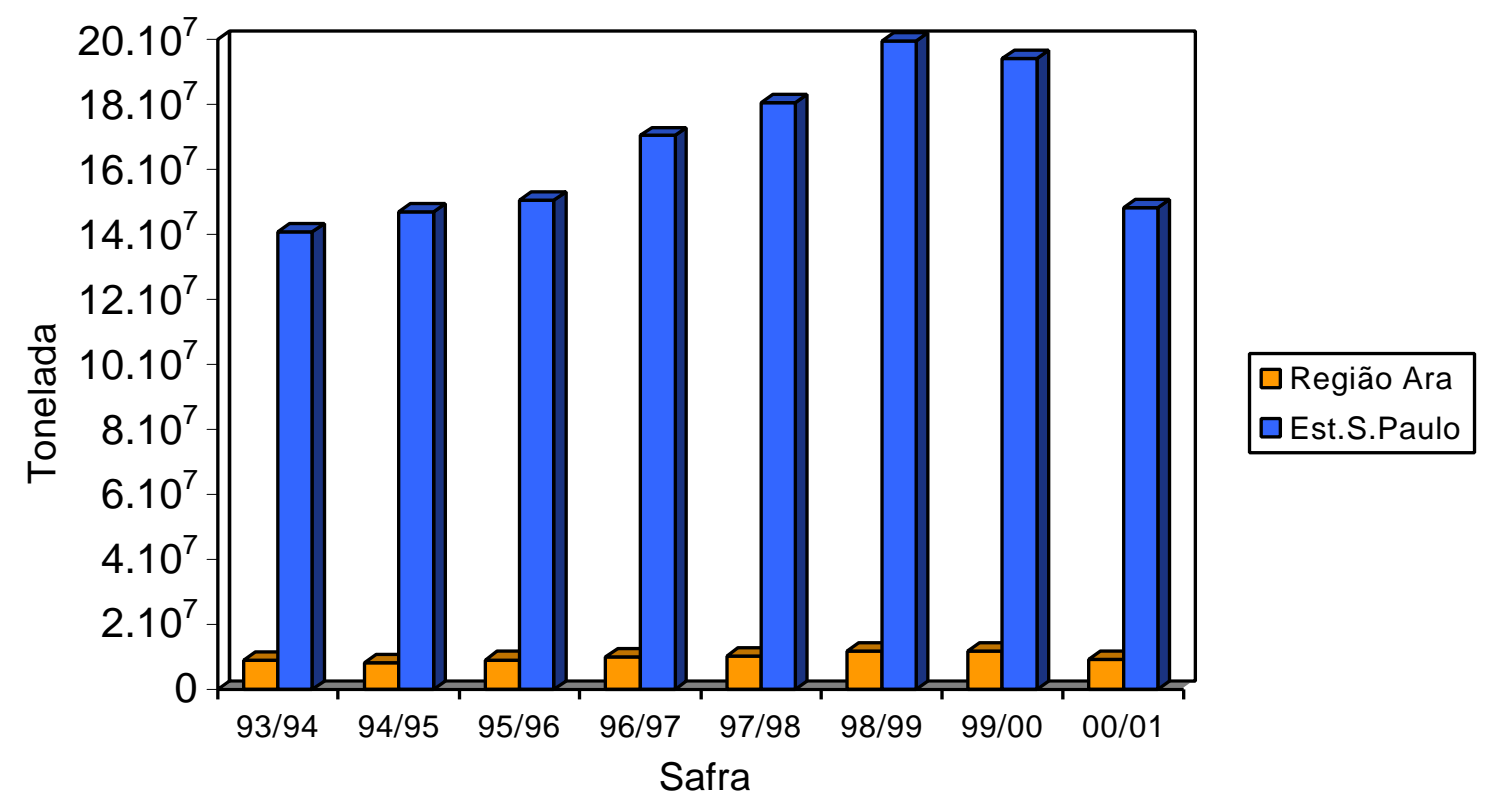

Figura 23. Produção da cana-de-açúcar (em toneladas) na região de Araraquara e no Estado de São Paulo (1993-2001) (ÚNICA, 2001). 
Anualmente, entre os meses de abril e novembro, há a queimada da cana-de-açúcar. Existiam até o momento deste estudo, exíguos dados que quantificassem o material particulado proveniente da queima da cana-deaçúcar. A CETESB eventualmente efetua a medição de gases e elementos particulados, porém nem sempre em períodos coincidentes com a queimada da cana.

\subsection{Medidas do material particulado}

A WHO (1999) recomenda que não sejam inviabilizados estudos epidemiológicos envolvendo material particulado pela falta de recursos tecnológicos sofisticados. Na falta de medidores de $\mathrm{PM}_{2,5}$ ou $\mathrm{PM}_{10}$ devem ser utilizados medidores de partículas totais em suspensão, ou, até mesmo, índices de visibilidade horizontal . Como não dispúnhamos de medidores nem de dados de visibilidade, desenvolvemos para este estudo uma metodologia de mensuração do material particulado produzido pela fuligem da cana.

Entre 28/05/1995 e 31/08/1995, quantificamos diariamente, em mg, o sedimento proveniente da fuligem da cana. Foram escolhidos dois pontos, um dos quais na região central da cidade, e um segundo na região rural, distante aproximadamente dez quilômetros em linha reta (figura 24). 


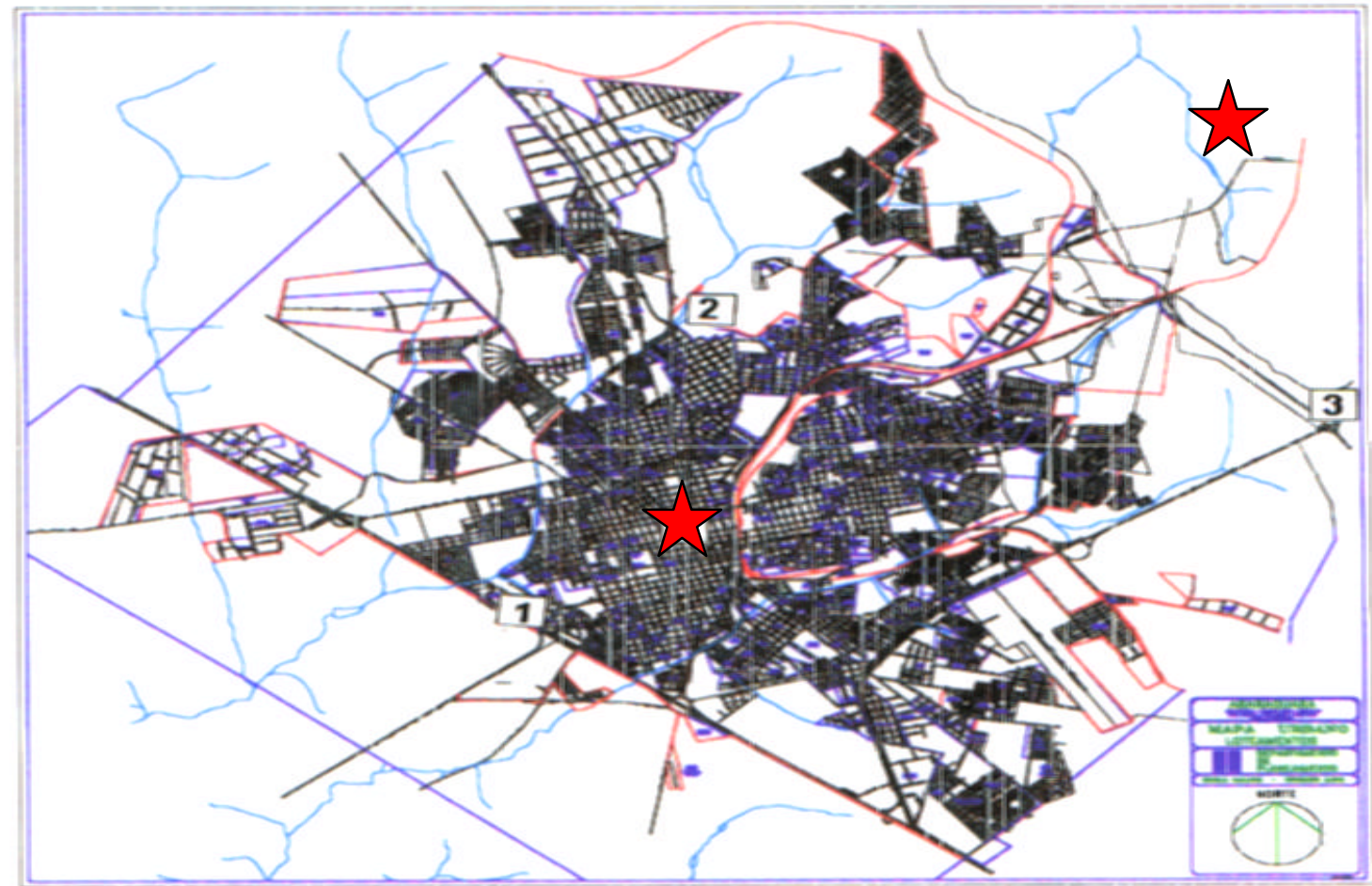

Figura 24. Mapa de Araraquara demonstrando os locais de amostragem (H).

Diariamente, em cada ponto, às sete horas da manhã, eram colocados dois recipientes de plástico com um litro de água de torneira, sobre tijolos, e distantes trinta centímetros do chão (figura 25).

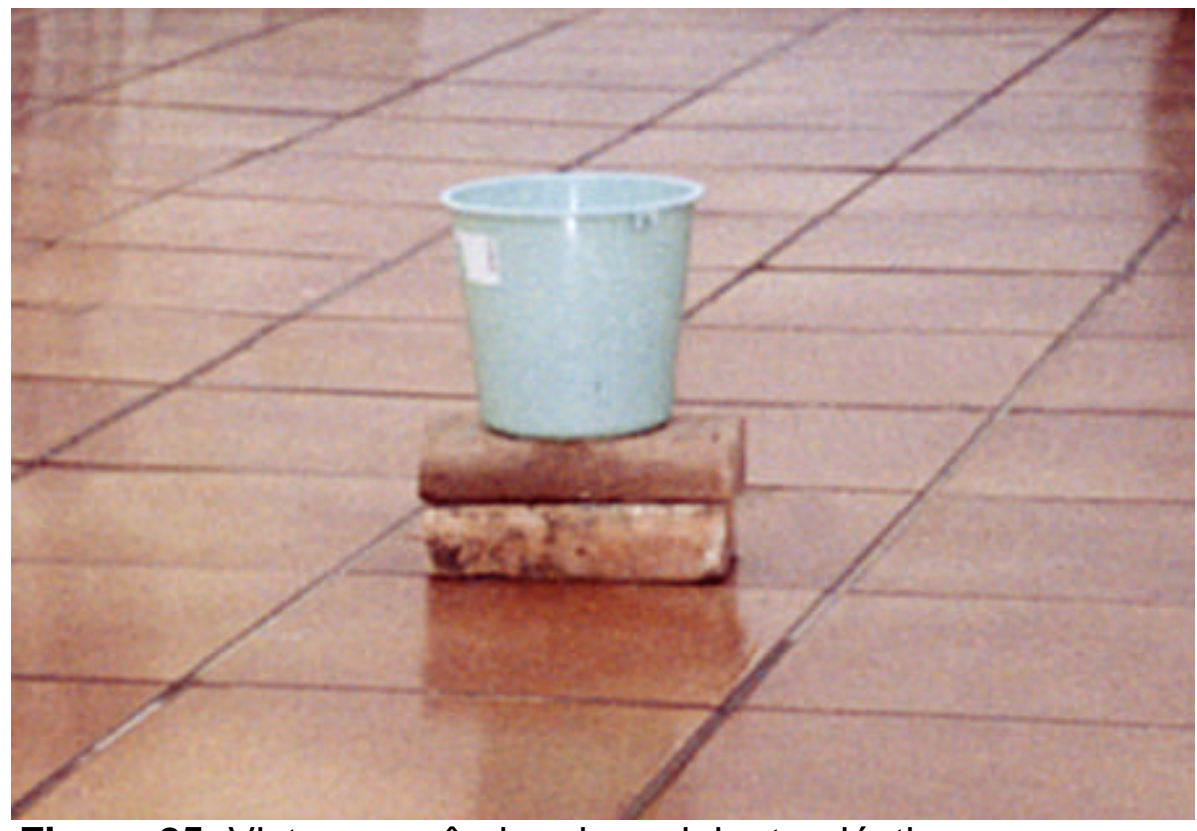

Figura 25. Vista panorâmica do recipiente plástico. 
Os recipientes eram colocados pareados para evitar uma possível perda acidental ou mesmo contaminação por insetos ou qualquer outra substância estranha. Os recipientes eram marca Plasvale, referência 171, com capacidade para dois e meio litros, e tinham as seguintes medidas: 15,5 $\mathrm{cm}$ de altura, $12 \mathrm{~cm}$ de diâmetro na base inferior e $16 \mathrm{~cm}$ de diâmetro na abertura superior. A fuligem era coletada por sedimentação simples e retida pela água, durante um período de vinte e quatro horas, uma vez que os recipientes eram lacrados às sete horas do dia seguinte, após exame visual do conteúdo (figura 26)

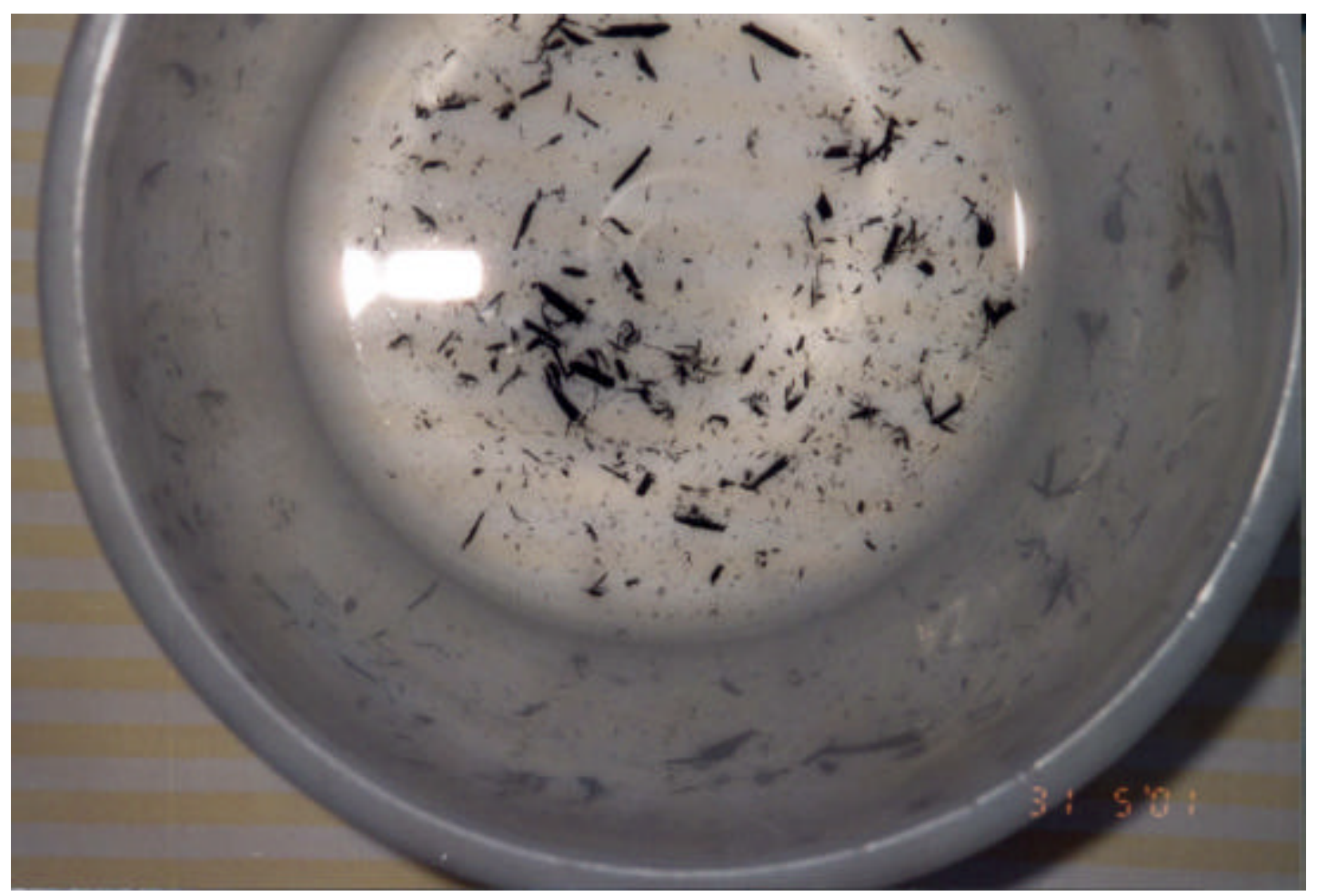

Figura 26. Detalhe da fuligem depositada no recipiente plástico. 
Os recipientes eram encaminhados ao Instituto de Química da UNESP, em Araraquara, onde a quantidade da fuligem em cada recipiente era medida, utilizando o seguinte método:

1) A amostra (água+fuligem) era filtrada em papel quantitativo previamente secado até peso constante e pesado. (filter paper whatman, 41).

2) Após a filtração a amostra retida no papel de filtro era secada em estufa, a uma temperatura de $60^{\circ}$ Centígrados até peso constante.

3) Através do peso obtido, após a secagem, calculava-se a quantidade de fuligem retida no papel de filtro.

4) Peso da fuligem = peso do papel + fuligem - peso do papel.

5) As pesagens eram realizadas em balanças semi-analíticas marca OWALABOR (peso máximo $160 \mathrm{~g}$ - peso mínimo 0,5 g).

O peso do sedimento proveniente da fuligem (média aritmética do peso de fuligem obtida nos quatro recipientes plásticos) foi considerado como indicador diário de poluição na cidade de Araraquara no período do estudo.

\subsection{Medidas da Morbidade Respiratória}

Apesar de Araraquara ter um amplo sistema público de assistência à saúde, não havia na rede um registro adequado de atendimentos e/ou procedimentos que pudesse ser utilizado como marcador de morbidade. 
Utilizamos a contagem diária de pacientes que necessitaram terapêutica inalatória no serviço de emergência de um dos principais Hospitais de Araraquara, o Hospital São Paulo. O Hospital São Paulo é um hospital privado. Pertence à Unimed, uma cooperativa médica, que tem como objetivo prestar serviços médicos, tanto para pessoas físicas (plano particular), como para pessoas jurídicas (empresas). A prestação de serviços médicos para empresas é feita em duas modalidades: prépagamento, em que a empresa contrata os serviços médicos para seus funcionários, através de um valor fixo mensal, e pós-pagamento, em que o valor pago mensalmente é a soma dos serviços utilizados.

O número de usuários da organização à época do estudo era de 95527.

O Serviço de Emergência do Hospital São Paulo funcionava ininterruptamente durante vinte e quatro horas, com equipes que se revezavam em regime de plantões. No ano do estudo cada equipe era composta por um clínico geral e um pediatra além do pessoal de apoio necessário a esse tipo de atendimento. Eram equipes constantes a cada dia da semana, o que nos permitiu considerar uma homogeneidade, tanto nos procedimentos médicos, como na conduta terapêutica. Após o atendimento, o paciente recebia a medicação de emergência e, em seguida, era encaminhado ou para internação ou ao seu médico assistente, para continuidade do tratamento. Salientamos que durante os finais de semana havia um aumento do número de pacientes que procuravam o serviço de emergência, uma vez que, a maioria dos consultórios médicos da cidade, encontravam-se fechados. 
A terapêutica inalatória em unidades de emergência é utilizada ou como terapêutica isolada ou como terapêutica coadjuvante, em patologias respiratórias no período de agudização (PEREIRA, 1996; SOCIEDADE BRASILEIRA DE PNEUMOLOGIA E TISIOLOGIA, 1998).

Avaliamos, de maneira retrospectiva, o número diário de inalações que eram realizadas no serviço de emergência do Hospital São Paulo, no período entre 28 de maio e 31 de agosto de 1995, independente da hora do dia, do sexo, da idade ou da patologia. A contagem era iniciada às $7 \mathrm{~h}$ da manhã. Não foi informado aos médicos plantonistas a possibilidade de utilizar o número de inalações no estudo.

O número diário de pacientes que utilizaram terapêutica inalatória no Serviço de Emergência foi considerado como estimativa da morbidade respiratória na cidade de Araraquara no período do estudo.

\subsection{Dados Meteorológicos}

Utilizamos dados obtidos na divisão de Araraquara da Secretária Estadual de Agricultura e Abastecimento. Obtivemos relatórios diários sobre temperatura e índice pluviométrico. A temperatura era avaliada em dois horários distintos (07 e 19 horas) Utilizamos em nosso estudo a temperatura mínima diária, uma vez que trabalhos anteriores realizados no Laboratório de Poluição Atmosférica Experimental sugerem ser essa medida a mais 
indicada para estudos semelhantes ao nosso (SALDIVA et al, 1994, SALDIVA et al, 1995, EL KHOURI MIRAGLIA, 1997, LIN, 1997, BRAGA, 1998, PEREIRA. 1999).

\subsection{Análise Estatística}

Para descrever os comportamentos das variáveis (peso do sedimento proveniente da fuligem, número de inalações, temperatura mínima) durante o período de estudo, foram calculadas medidas descritivas (média, médiana, desvio padrão, valores mínimo e máximo) dessas variáveis e construídos gráficos do número de inalações, da temperatura e do peso do sedimento ao longo do período de estudo.

A associação entre as medidas do peso do sedimento proveniente da fuligem da cana foi estimada por meio de regressão linear simples.

As correlações entre o número diário de pacientes que necessitaram de inalações, o peso diário do sedimento e a temperatura mínima foram avaliadas por meio de coeficientes de correlação de Pearson.

Com o objetivo de avaliar a associação entre o número de inalações e o peso do sedimento utilizamos modelos de regressão múltipla. A finalidade da utilização de modelos de regressão no estudo é adequar os dados de um estudo a uma equação de regressão que modele com precisão a variável dependente, também chamada variável de interesse ou variável resposta (no 
nosso caso, o número diário de inalações) como função de variáveis explicativas, também chamada de variáveis independentes (no nosso caso peso do sedimento proveniente da fuligem). O objetivo é avaliar o "efeito" do peso do sedimento (representado pelo coeficiente estimado no modelo de regressão) no número de inalações, controlando-se fatores que sejam potenciais confundidores da associação estudada (no caso, temperatura mínima diária, fim de semana e sazonalidade).

O número diário de inalações é um evento de contagem. Em geral contagens apresentam distribuição de Poisson. Portanto, foram utilizados neste estudo modelos de regressão de Poisson.

A distribuição de Poisson permite uma boa aproximação da distribuição binomial para eventos raros, cuja ocorrência se dê de forma aleatória, com valores inteiros e não negativos, distribuídos em períodos de tempo fixo, como por exemplo, em dias, semanas, meses ou ano (KLEINBAUN et al, 1988, LINN, 1997, BRAGA, 1998, PEREIRA, 1999), tendo sido considerada como uma metodologia de análise mais adequada para esse tipo de estudo.

KLEINBAUM et al. (1988), definem matematicamente o modelo de regressão de Poisson pela seguinte fórmula:

$$
\ln \lambda_{t}=\alpha+\Sigma \beta_{i} X_{i t}
$$

onde In $\lambda_{\mathbf{t}}$ é o logarítimo natural da variável de interesse, $\mathbf{X}_{\mathrm{it}}$ são as variáveis independentes, $\alpha$ e $\beta_{\mathbf{i}}$ são os parâmetros a serem estimados. 
A relação entre os desfechos utilizados nos estudos epidemiológicos de séries temporais e algumas covariáveis mais freqüentemente utilizadas, como, por exemplo, a temperatura, pode não ser linear. Temperaturas extremas, tanto altas quanto baixas, têm sido associadas com aumentos na morbidade e na mortalidade. Para permitir uma estimativa mais adequada desses comportamentos potencialmente não lineares utilizamos os modelos aditivos generalizados (MAG). Esses modelos permitem o ajuste de funções não paramétricas (também chamadas de alisadores) para modelar relações não lineares que não tem forma definida (SCHWARTZ, 1994e).

HASTIE e TIBSHIRANI, 1990 apresentam uma série de alisadores como, por exemplo, os "cubic somootihing splines" ou o "locally weighted running line smooth (loess)", que podem ser úteis para representar tanto a sazonalidade quanto a relação entre o número de inalações e a temperatura. As duas considerações mais importantes para a escolha do alisador envolvem o tipo de média a ser calculada e o tamanho da vizinhança. Esse último, também chamado de parâmetro de alisamento, determina o compromisso entre o viés e a variância do alisador. Intuitivamente, quanto maior o tamanho da vizinhança, mais lisa será a curva e, em geral, maior o viés (CONCEIÇÃO, 1999). 
O modelo ficou assim definido:

$\log [E($ Inalações $)]=\alpha_{0}+S_{1}$ (Dias Transcorridos $)+S_{2}($ Temperatura $)+$ $\beta_{1}$ segunda feira $+\beta_{2}$ terça feira $+\beta_{3}$.quarta feira $+\beta_{4}$ quinta feira $+\beta_{5}$.sexta feira+ $\beta_{6}$ sábado+ $\beta$ (fuligem)

onde $E$ (Inalações) é o valor esperado da contagem diária de inalações, $S_{i}$ é a função de alisamento ( $\mathrm{i}=1,2)$ e $\quad \beta_{i}$ é o coeficiente dos termos lineares. $(\mathrm{j}=1, \ldots, 7)$

O parâmetro de alisamento para modelar a sazonalidade foi escolhido com o objetivo de minimizar a soma da autocorrelação dos resíduos, removendo os padrões sazonais de longa duração (SCHWARTZ,1994e). O parâmetro de alisamento da temperatura foi escolhido com o objetivo de minimizar o Critério de Informação de Akaike (AKAIKE, 1973).

Foi utilizada regressão robusta (M-estimator), que confere pesos menores às observações extremas na variável resposta. Para excluir observações extremas na variável resposta, excluímos da análise os $5 \%$ dos dias com menos inalações e $5 \%$ dos dias com mais inalações.

Segundo POPE; SCHWARTZ (1996), os efeitos da poluição atmosférica sobre a saúde podem ser causados não apenas pelo dia de exposição imediato, mas também pela exposição em dias anteriores. Utilizamos os valores diários do peso do sedimento, e também médias 
móveis de dois a cinco dias para explorar possíveis defasagens entre a exposição ao poluente e os efeitos sobre a saúde. Assim, por exemplo, a média móvel de três dias é a média aritmética da concentração do poluente do dia em questão e dos dois dias anteriores.

Para verificar se a relação entre o número de inalações e o peso do sedimento é dose-dependente, ajustamos um modelo similar ao modelo descrito acima utilizando quatro categorias do peso do sedimento (os $25 \%$ dos valores mais baixos, entre 25 e $50 \%$, entre 50 e $75 \%$ e os $25 \%$ mais altos) em lugar da variável continua.

A estimativa do Risco Relativo é dada pela função exponencial do B $\left(?^{\beta}\right)$, (em que $\beta$ é o coeficiente de regressão) para cada quartil, enquanto o intervalo de confiança dessas estimativas é dado por:

$$
I_{95 \%}(R R)=?^{[B \pm 1.96 \text { e.p.(B)] }}
$$

Onde e.p. é o erro padrão de ß

As análises estatísticas foram realizadas utilizando o software SPSS versão 9.0 (SPSS Inc.) e SPlus version 4.5 (MathSoft Inc.). 
4. RESULTADOS 


\subsection{Análise descritiva das variáveis do estudo}

\subsubsection{Características da população estudada}

A proporção entre usuários e não usuários do convênio Unimed na cidade de Araraquara durante o período do estudo é visto na figura 27 . 0 percentual da população que possuía o plano privado de assistência médica “Unimed" era superior a 50\%.

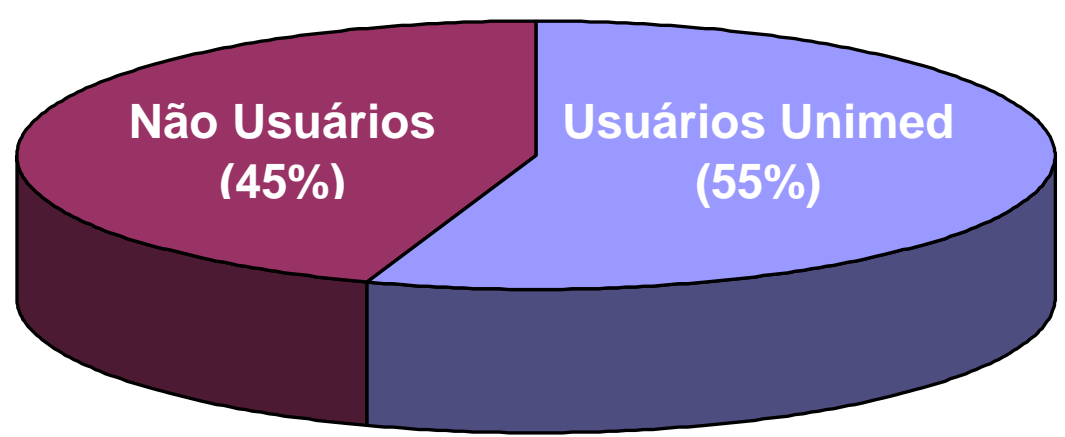

Figura 27. Distribuição percentual entre usuários e não usuários do convênio médico Unimed na cidade de Araraquara no ano de 1995. 


\subsubsection{Inalações}

\subsubsection{Análise Descritiva do Número de Inalações.}

A tabela 14 mostra a análise descritiva mensal e o total do número de inalações durante os 97 dias do estudo.

Tabela 14. Análise descritiva do número de inalações no período do estudo.

\begin{tabular}{|l|c|c|c|c|c|}
\hline Variáveis & $\begin{array}{c}\text { Maio } \\
\text { (6 dias) }\end{array}$ & $\begin{array}{c}\text { Junho } \\
\text { (30 dias) }\end{array}$ & $\begin{array}{c}\text { Julho } \\
\text { (30 dias) }\end{array}$ & $\begin{array}{c}\text { Agosto } \\
\text { (31 dias) }\end{array}$ & $\begin{array}{c}\text { Total } \\
\text { (97 dias) }\end{array}$ \\
\hline \multicolumn{1}{|c|}{$\begin{array}{l}\text { Número de } \\
\text { Inalações }\end{array}$} & & & & & \\
Média & 37 & 32 & 19 & 12 & 22 \\
Médiana & 36 & 31 & 18 & 10 & 20 \\
Desvio Padrão & 16 & 10 & 08 & 06 & 13 \\
Mínimo & 20 & 15 & 06 & 04 & 04 \\
Máximo & 66 & 60 & 41 & 26 & 66 \\
\hline
\end{tabular}

A tabela 14 sugere uma queda na média de inalações no serviço de emergência no decorrer do período. O número máximo de inalações em um único dia foi observado no início do período (maio), enquanto que o número mínimo de inalações ocorreu em 4 de agosto, confirmando a tendência de queda. 


\subsubsection{Sazonalidade das Inalações ao Longo do Período.}

A figura 28 sugere a tendência de queda do número diário de inalações no decorrer do período.

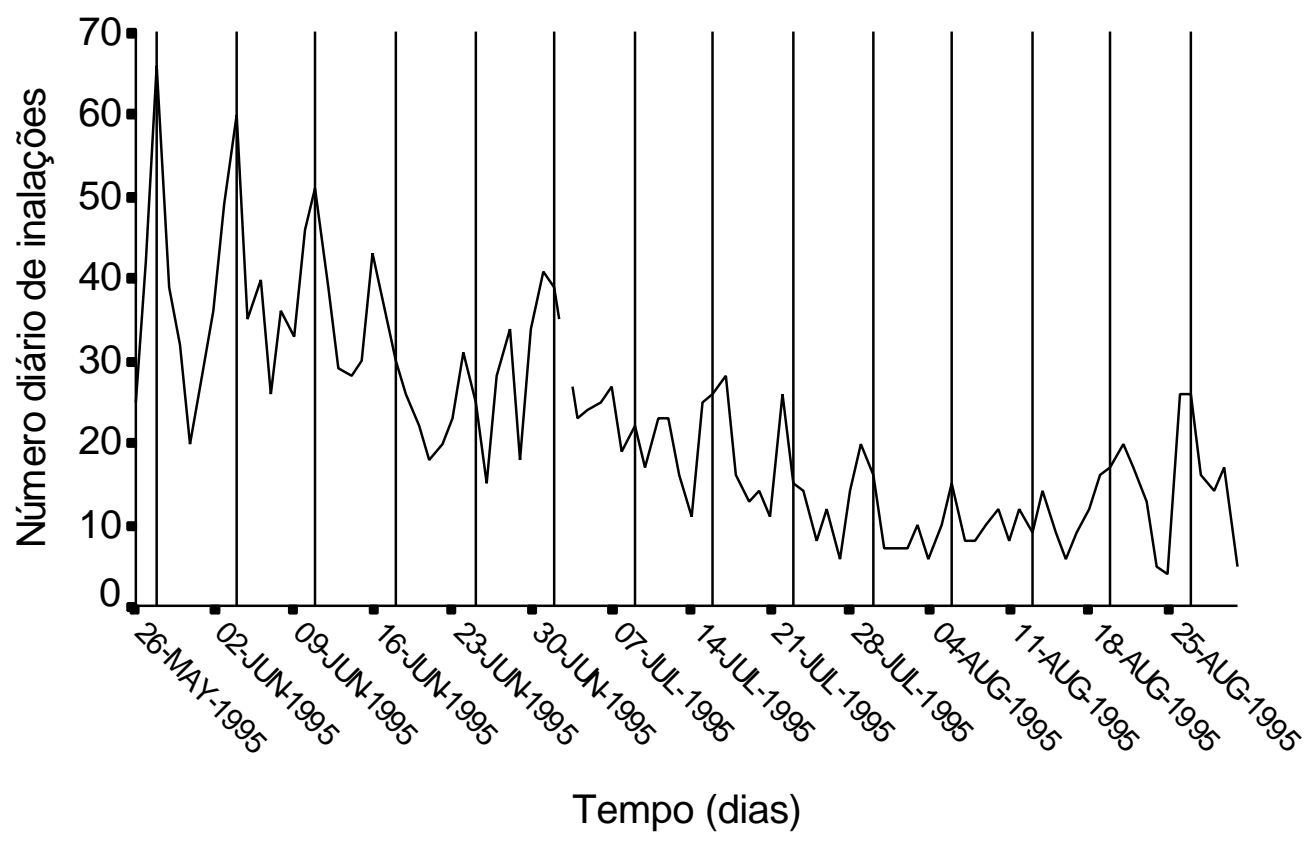

As linhas verticais correspondem aos finais de semana.

Figura 28. Variação diária no número de inalações no período do estudo. 


\subsubsection{Sazonalidade Semanal do Número de Inalações}

Os consultórios médicos, em geral, permaneciam fechados durante os feriados e finais de semana. Isso provocava uma maior procura por parte dos pacientes ao Serviço de Emergência, e, conseqüentemente, um aumento do número de inalações. A figura 29 mostra a variação do número médio das inalações, de acordo com os dias da semana durante o período do estudo.

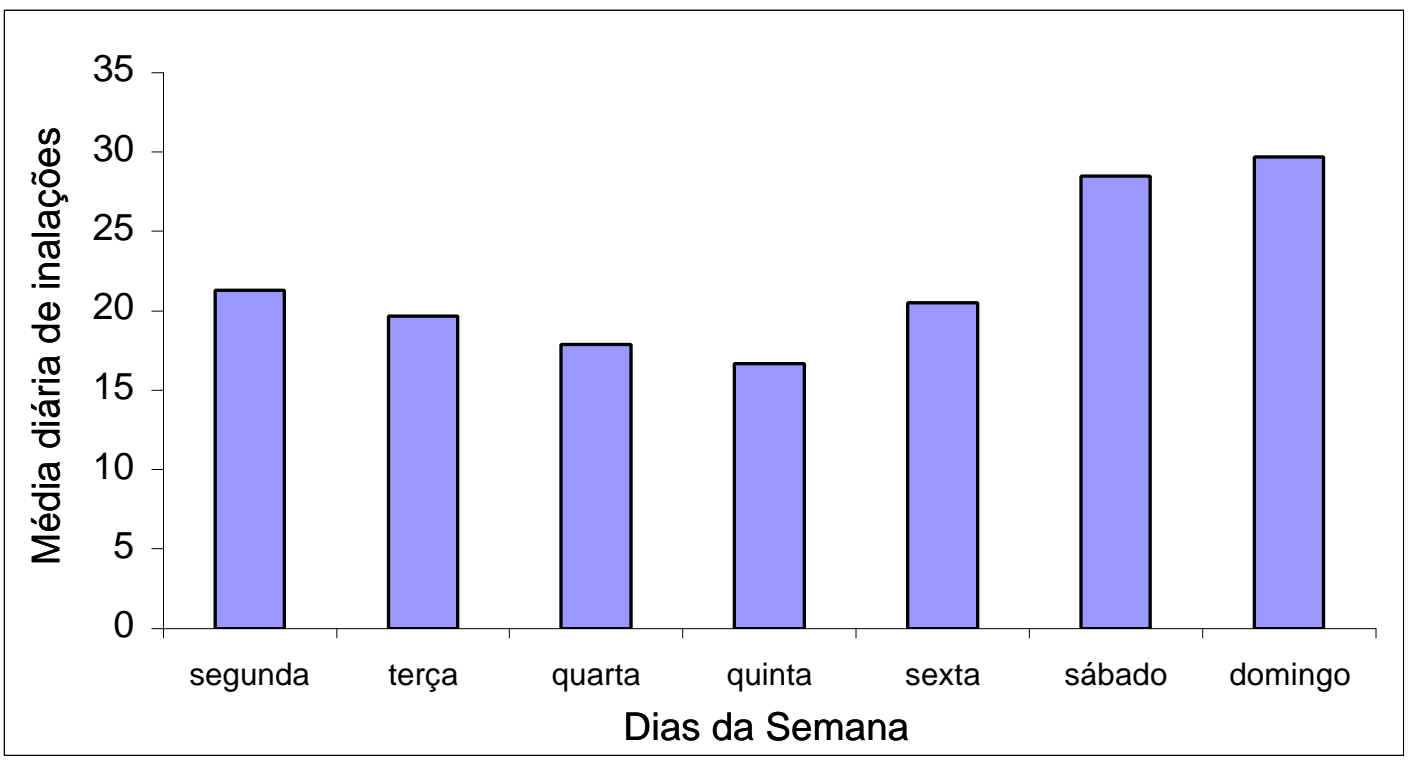

Figura 29. Número médio de inalações de acordo com os dias da semana no serviço de emergência do Hospital São Paulo, durante o período do estudo. 


\subsubsection{Peso do sedimento}

\subsubsection{Correlação Linear do Peso do Sedimento}

A figura 30 mostra a associação entre as medidas diárias do peso do sedimento nos dois locais (central e rural) utilizados durante o estudo.

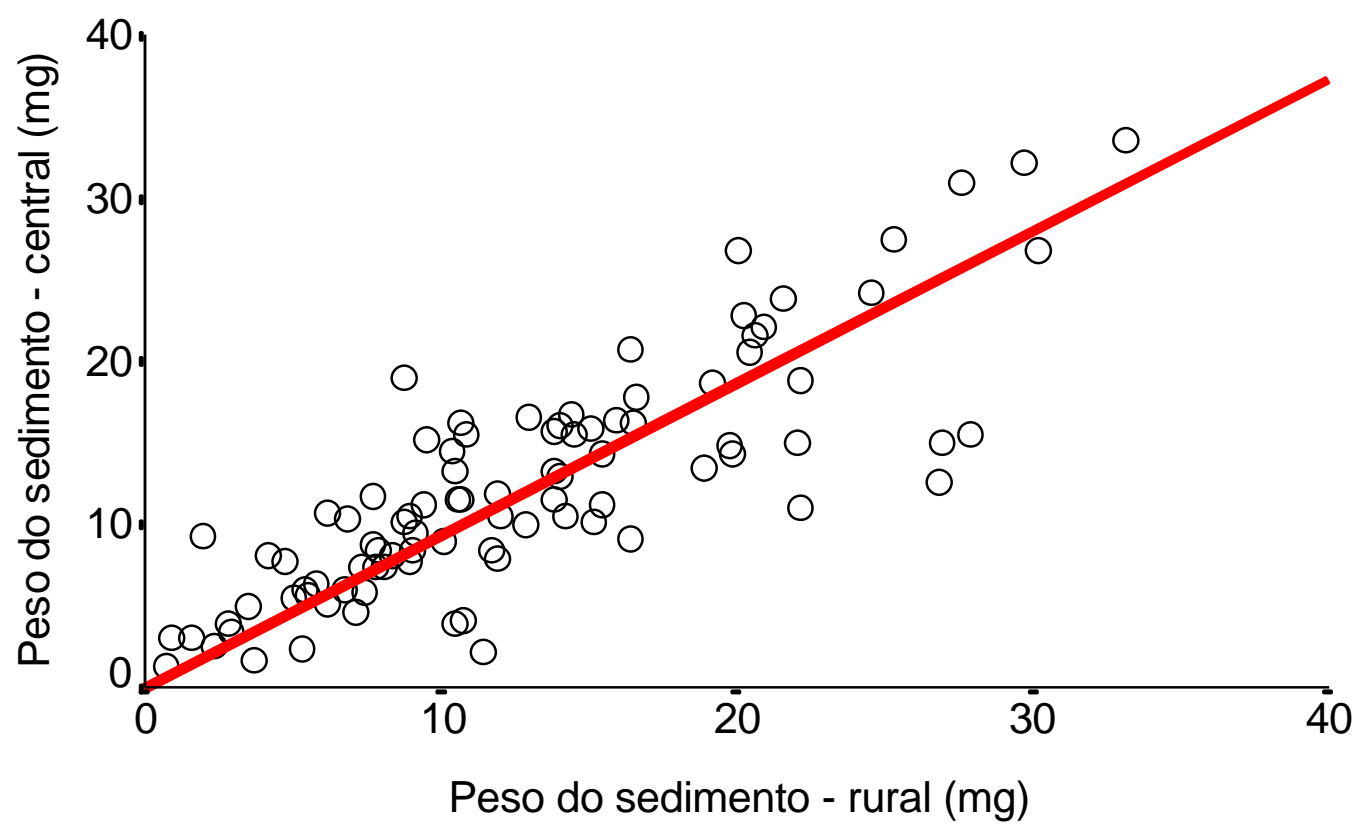

Figura 30. Correlação entre as médias do peso do sedimento $(\mathrm{mg})$ medidas na área central e na área rural da cidade de Araraquara.

Cada ponto representa a média das duas medidas realizada em cada local. Há uma correlação positiva e estatisticamente significativa $\left(r^{2}=0,92 ; p\right.$ $<0,0001)$ entre as medidas realizadas na área central e aquelas realizadas na zona rural. Esse fato permitiu que utilizássemos no estudo uma única medida (valor médio do peso do sedimento diário) como indicador da deposição da fuligem na cidade de Araraquara. 


\subsubsection{Análise Descritiva do Peso do Sedimento.}

A tabela 15 mostra a análise descritiva da média do peso do sedimento medido nos dois locais escolhidos durante o período do estudo.

Tabela 15. Análise descritiva do peso do sedimento no período do estudo.

\begin{tabular}{|l|c|c|c|c|c|}
\hline Variáveis & $\begin{array}{c}\text { Maio } \\
\text { (6 dias) }\end{array}$ & $\begin{array}{c}\text { Junho } \\
\text { (30 dias) }\end{array}$ & $\begin{array}{c}\text { Julho } \\
\text { (30 dias) }\end{array}$ & $\begin{array}{c}\text { Agosto } \\
\text { (31 dias) }\end{array}$ & $\begin{array}{c}\text { Total } \\
\text { (97 dias) }\end{array}$ \\
\hline $\begin{array}{l}\text { Peso do } \\
\text { Sedimento (mg) }\end{array}$ & 6.3 & 17.3 & 13.4 & 9.3 & 12.9 \\
Média & 5.8 & 16.0 & 12.5 & 9.4 & 12.0 \\
Médiana & 3.1 & 7.4 & 6.4 & 4.5 & 7.0 \\
Desvio Padrão & 2.4 & 1.1 & 2.4 & 2.6 & 1.1 \\
Mínimo & 11.2 & 33.5 & 28.6 & 24.5 & 33.5 \\
Máximo & & & & \\
\hline
\end{tabular}

Com exceção dos valores observados nos sete primeiros dias de mensuração da fuligem (entre 26 de maio e 1 de junho de 1995), quando foram registrados valores muito aquém do esperado para aquela época do ano, houve um decréscimo na média do peso do sedimento ao longo do período do estudo, acompanhando a queda na média diária das inalações. 


\subsubsection{Sazonalidade do Peso do Sedimento ao Longo do Período.}

A figura 31 indica uma tendência de queda no peso do sedimento medido diariamente ao longo do período do estudo acompanhando a tendência de queda já mostrada, no número diário de inalações.

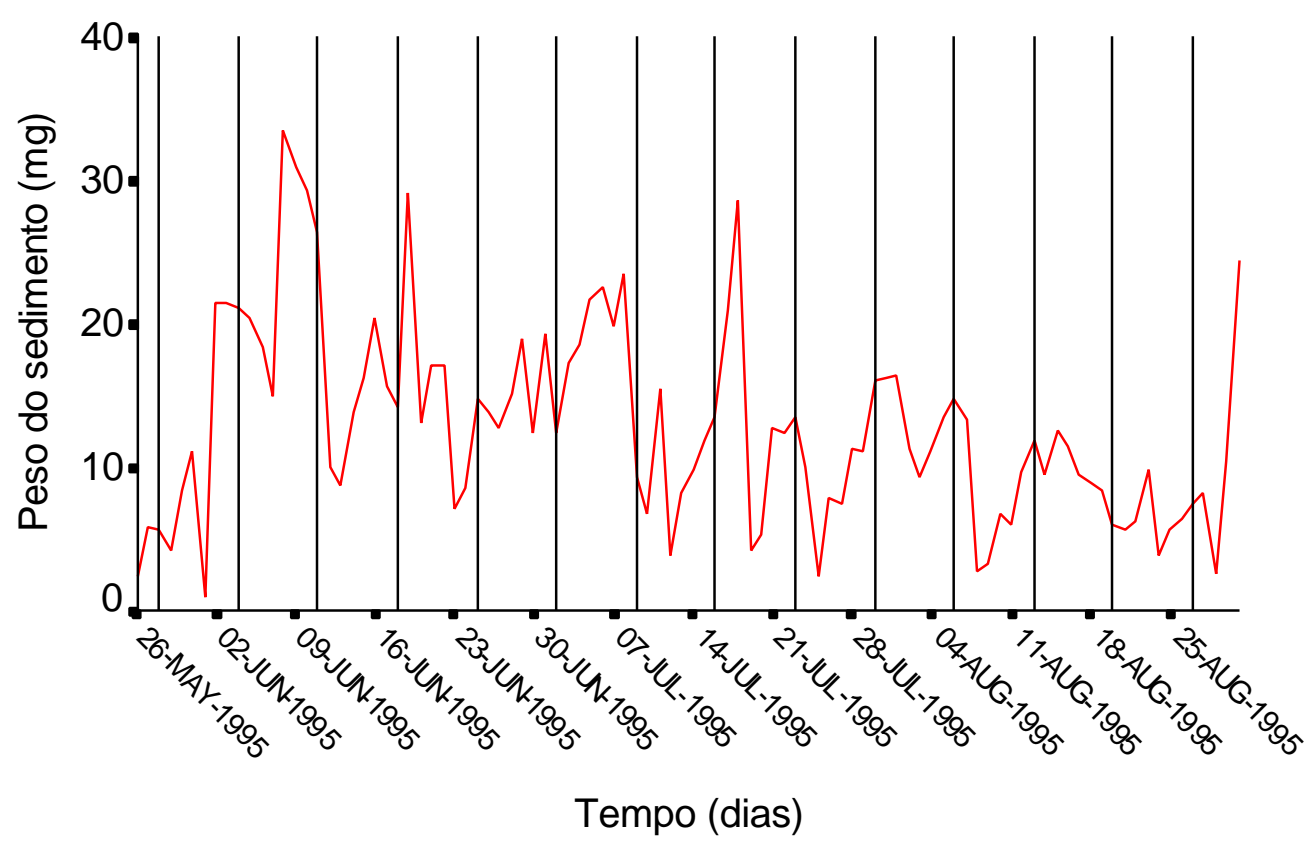

As linhas verticais indicam os finais de semana.

Figura 31. Variação diária do peso do sedimento no período do estudo 


\subsubsection{Temperatura}

\subsubsection{Análise Descritiva da Temperatura Mínima Diária.}

A tabela 16 mostra a análise descritiva da temperatura ao longo do período do estudo.

Tabela 16. Análise descritiva da temperatura mínima diária no período do estudo

\begin{tabular}{|l|c|c|c|c|c|}
\hline \multicolumn{1}{|c|}{ Variáveis } & $\begin{array}{c}\text { Maio } \\
\text { (6 dias) }\end{array}$ & $\begin{array}{c}\text { Junho } \\
\text { (30 dias) }\end{array}$ & $\begin{array}{c}\text { Julho } \\
\text { (31 dias) }\end{array}$ & $\begin{array}{c}\text { Agosto } \\
\text { (31 dias) })\end{array}$ & $\begin{array}{c}\text { Total } \\
\text { (97 dias) }\end{array}$ \\
\hline $\begin{array}{l}\text { Temperatura } \\
\left.\text { Mínima ( }{ }^{\circ} \mathbf{C}\right)\end{array}$ & & & & & \\
Média & 16.0 & 17.6 & 18.5 & 21.1 & 18.9 \\
Médiana & 16.0 & 17.0 & 19.0 & 21.0 & 19.0 \\
Desvio Padrão & 1.4 & 2.5 & 2.2 & 1.3 & 2.6 \\
Mínimo & 14.0 & 13.0 & 14.0 & 18.0 & 13.0 \\
Máximo & 18.0 & 23.0 & 22.0 & 24.0 & 24.0 \\
\hline
\end{tabular}

O menor valor para temperatura mínima em todo o período foi de $13^{\circ} \mathrm{C}$ em junho. Considerando os valores registrados no período do estudo, final de outono e início de inverno, podemos constatar que Araraquara está acostumada a temperaturas altas, sem variações acentuadas. 


\subsubsection{Sazonalidade da Temperatura Mínima Diária ao Longo do Período do Estudo.}

A figura 32 sugere a tendência de aumento da temperatura mínima diária com o decorrer dos dias no período do estudo.

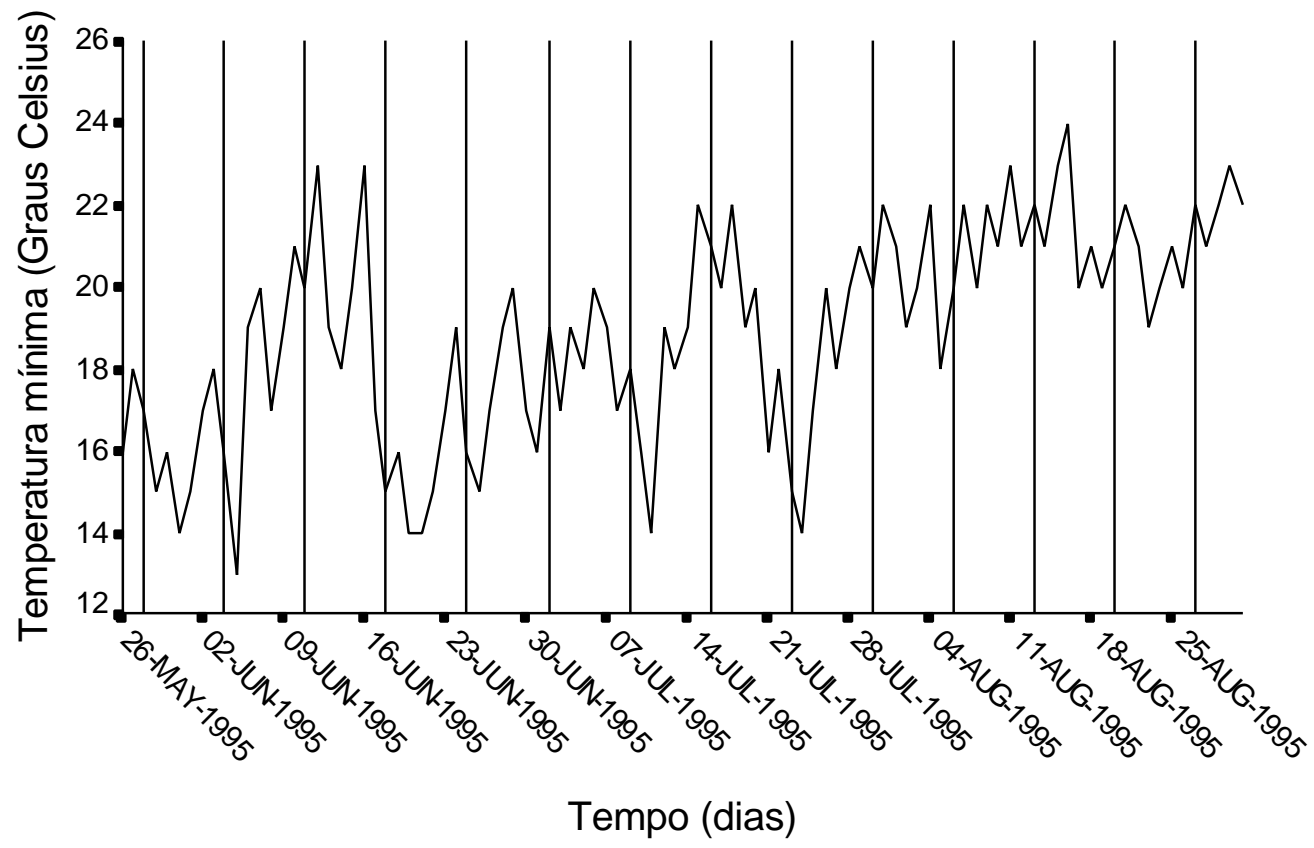

As linhas verticais indicam os finais de semana.

Figura 32. Variação diária da temperatura mínima durante o período de estudo. 


\subsection{Análise estatística.}

\subsubsection{CORRELAÇÃO DE PEARSON.}

Com a finalidade de se obter uma avaliação inicial de como as variáveis principais do modelo estão relacionadas foi calculado o coeficiente de correlação de Pearson para as variáveis no número de inalações, peso do sedimento, e temperatura mínima (tabela 17).

Tabela 17. Coeficiente de correlação de Pearson para as principais variáveis do estudo.

\begin{tabular}{|l|c|c|}
\hline & Número de Inalações & Peso do Sedimento \\
\hline Peso do Sedimento & $0.36^{*}$ & \\
Temperatura Mínima & $-0.31^{*}$ & -0.10 \\
\hline
\end{tabular}

${ }^{*} \mathrm{p}<0.01$

Há uma correlação significante e negativa entre a temperatura mínima e o número de inalações. Há uma correlação positiva e significante entre o peso do sedimento e o número de inalações. Não foi observada correlação significativa entre peso do sedimento e temperatura mínima. 


\subsubsection{MODELOS DE REGRESSÃO DE POISSON}

Foram ajustados parâmetros de alisamento em função da temperatura mínima e em função do número de dias transcorridos com o objetivo de controlar as variações sazonais de longa duração. A figura 33 apresenta um exemplo de alisamento para sazonalidade.

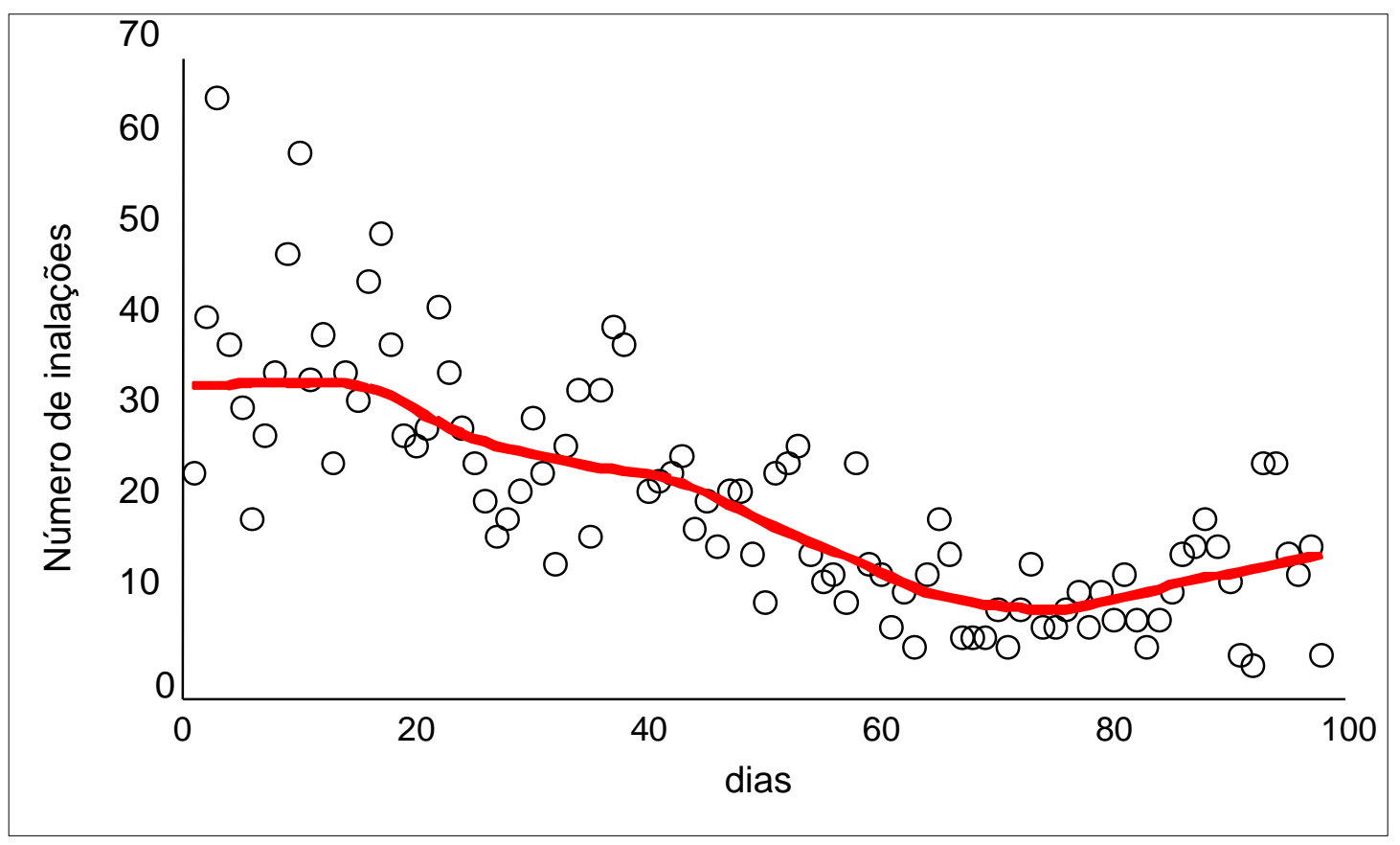

Figura 33. Curva de alisamento do número de inalações em função do número de dias transcorridos

O parâmetro de alisamento para dias transcorridos foi 0,45 e para temperatura mínima foi 0,5 . 
A tabela 18 mostra os coeficientes de regressão para o peso do sedimento diário e para as médias móveis de dois até cinco dias.

Tabela 18. Coeficientes de regressão e intervalos de confiança de $95 \%$ para o peso do sedimento (níveis diários e médias moveis) em modelos controlados para sazonalidade, fim de semana e temperatura mínima.

\begin{tabular}{|c|c|c|}
\hline Peso do Sedimento & Coeficientes & Intervalo de Confiança 95\% \\
\hline Dia & 0,00649 & $-0,00070 ; 0,01090$ \\
Média Móvel 2 dias & $0,00862^{*}$ & 0,$00007 ; 0,01717$ \\
Média Móvel 3 dias & 0,00820 & $-0,00220 ; 0,01860$ \\
Média Móvel 4 dias & 0,08231 & $-0,00251 ; 0,01891$ \\
Média Móvel 5 dias & 0.00914 & $-0,00301 ; 0,02121$ \\
\hline
\end{tabular}

${ }^{\star} p<0,05$

O número diário de inalações esteve positivamente associado com o peso do sedimento do dia do evento bem como com as médias móveis de dois até cinco dias. Entretanto, apenas o efeito da média móvel de dois dias apresentou significância estatística. 
A tabela 19 mostra os valores de coeficientes e intervalos de confiança para todas as variáveis incluídas no modelo final.

Tabela 19. Coeficientes e intervalos de confiança de $95 \%$ para as variáveis no modelo final.

\begin{tabular}{|l|c|c|}
\hline & Coeficientes & $\begin{array}{c}\text { Intervalo de Confiança } \\
\text { de 95\% }\end{array}$ \\
\hline Peso do Sedimento $(\mathrm{mg})^{*}$ & 0.00862 & $0.00007,0.01717$ \\
Tempo (dias) & -3.7631 & $-5.1033,-2.4229$ \\
Temperatura $\left({ }^{\circ} \mathrm{C}\right)^{*}$ & 0.4456 & $-0.7660,1.6572$ \\
Fim de Semana & 0.3329 & $0.0997,0.5661$ \\
\hline
\end{tabular}

${ }^{*}$ Média Móvel de Dois Dias

Com base no coeficiente encontrado estimamos em 9\% o Risco Relativo de ocorrerem inalações para um aumento de $10 \mathrm{mg}$ no peso do sedimento.

Para determinar o padrão de associação entre exposição e doença utilizamos uma variável categórica construída com quartis da média móvel de dois dias e a utilizamos ao invés da variável contínua. As quatro categorias foram definidas da seguinte forma: 
$1^{\text {a }}$. categoria (quartil) - inclui os dias em que a concentração do poluente assumiu os valores $25 \%$ mais baixos do período.

$2^{a}$. categoria (quartil) - inclui os dias em que a concentração do poluente assumiu os valores entre 26 a $50 \%$.

$3^{a}$. categoria (quartil) - inclui os dias em que a concentração do poluente assumiu os valores entre 51 e $75 \%$

$4^{\mathrm{a}}$. categoria (quartil) - inclui os dias em que a concentração do poluente assumiu os valores mais altos do período (25\% mais elevados)

A figura 34 mostra o risco relativo e intervalo de confiança de 95\% para inalações de acordo com as quatro categorias de peso do sedimento.

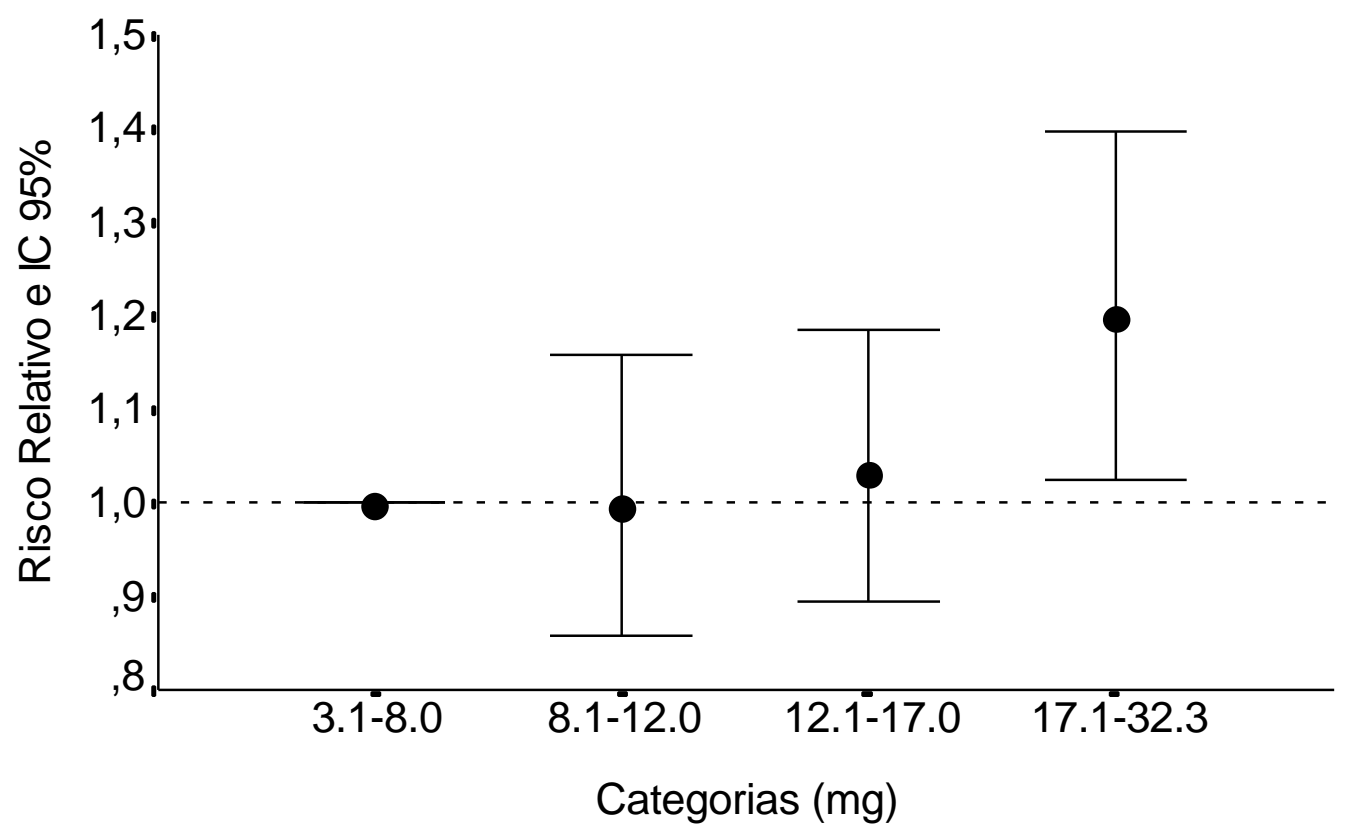

Figura 34. Risco relativo e intervalo de confiança de $95 \%$ para inalações com concentrações crescentes do sedimento (média móvel de dois dias) 
A figura 34 sugere que a relação entre o poluente estudado e o número de inalações é dose-dependente. O risco de a população necessitar de inalação aumenta proporcionalmente com o aumento da concentração do poluente. Comparada com a primeira categoria, adotada como referência (risco $=1$ ), a quarta categoria do peso do sedimento (acima de $17 \mathrm{mg}$ ) mostra uma significante associação com o número de inalações, exibindo um risco relativo de 1,20 em relação ao primeiro quartil $(1,03-1,39)$. Não houve evidência de autocorrelação significante nos modelos. 


\section{DISCUSSÃO}




\subsection{Aspectos Gerais}

Todo ano milhões de pessoas morrem ou sofrem sérios danos à sua saúde, causados pela poluição do ar. Os indivíduos portadores de doenças respiratórias (como asma, doença pulmonar obstrutiva crônica) e os portadores de doenças cardiovasculares são especialmente atingidos. A WHO (2000a), estima que a poluição do ar seja causa de cinco por cento de um total de cinqüenta e cinco milhões de mortes que ocorrem anualmente no planeta. Vários estudos tem mostrado associação positiva e estatisticamente significante entre medidores de mortalidade e de morbidade com concentrações diárias do material particulado em suspensão com diâmetro menor que $10 \mu \mathrm{m}$. Por isso, a expectativa de vida pode estar significativamente reduzida em comunidades com alto nível de material particulado (WHO, 2000a). Após os episódios agudos de poluição do ar ocorridos em Vale do Meuse, Bélgica (1930), Donora, Pensilvânia, EUA (1948) e Londres Inglaterra (1952), proliferaram estudos relacionando material particulado proveniente da queima de combustíveis fósseis com agravos à saúde. Segundo POPE; DOCKERY (1999) havia pelo menos cento e quarenta estudos publicados envolvendo efeitos sobre a saúde e poluição do ar por material particulado, entre 1987 e 1999. Desses, mais de 
cem foram escritos após 1992. Além disso, temos pelo menos dezessete revisões destes estudos epidemiológicos a partir de 1993. (OSTRO, 1993; LIPFERT, 1994; DOCKERY; POPE, 1994, 1996; BRUNEKREEF et al., 1995; FOLINSBEE, 1995; JEDRYCHOWSKI, 1995; KATSOUYANNI, 1995; LIPFERT; WYZGA, 1995; POPE et al., 1995b,c; SCHWARTZ, 1995; MOOLGAVKAR; LUEBECK, 1996; POPE; DOCKERY, 1996; THURSTON, 1996; US EPA, 1996b; VEDAL, 1997). Segundo a American Lung Association (2001), mais de 800 novos estudos científicos demonstrando a associação entre os efeitos deletérios do material particulado em suspensão no ar proveniente de combustíveis fósseis e agravos à saúde humana foram publicados após 1996, data em que a "USEPA" realizou a ultima revisão reavaliando a padronização do material particulado. Talvez por todos esses fatos expostos, a primeira idéia que se forma na mente das pessoas e do pesquisador é associar a poluição do ar aos grandes centros urbanos, centros esses geradores de material particulado através do cano de escapamento dos veículos ou das grossas e espessas fumaças das fábricas.

No Brasil, a utilização do álcool hidratado como combustível de veículos automotores, ou a mistura álcool anidro/gasolina na proporção de vinte e dois por cento de álcool, trouxe benefícios para o meio ambiente e para a saúde da população, principalmente a que reside nos grandes conglomerados urbanos. 
Um dos grandes benefícios que a utilização desses combustíveis trouxe foi a diminuição da emissão de compostos de chumbo para a atmosfera, em decorrência da substituição de antidetonante à base de chumbo pelo álcool misturado à gasolina (CETESB, 1997a).

Porém, a grande utilização do álcool como combustível em veículos automotores provocou um substâncial aumento da área utilizada para cultivo da cana-de-açúcar no Brasil e, especialmente, no Estado de São Paulo. Nas regiões em que a cana-de-açúcar é plantada, colhida e industrializada, a qualidade do ar foi prejudicada devido a um aumento da quantidade de cana queimada, o que gera um aumento de poluentes na atmosfera. Esses poluentes causam uma série de transtornos aos moradores das cidades afetadas pelas queimadas, em decorrência da presença de materiais indesejáveis que modificam as características do meio ambiente. Esse é um problema geral que atinge todas as regiões produtoras de cana-de-açúcar.

Em Araraquara, cidade localizada no centro da região canavieira do Estado de São Paulo e, portanto, diretamente interessada e afetada pelo problema, havia um crescente desejo de toda a comunidade para que houvesse um estudo que elucidasse o real impacto da poluição gerada pela queima de um tipo especifico de biomassa (cana-de-açúcar) sobre a população exposta. 
O Laboratório de Poluição Atmosférica Experimental do Departamento de Patologia da Faculdade de Medicina da Universidade de São Paulo foi o pioneiro em nosso país na avaliação dos efeitos tóxicos dos poluentes emitidos pela utilização de combustíveis fósseis nos grandes centros urbanos. Foi também o pioneiro na avaliação dos efeitos tóxicos da combustão do álcool, da mistura álcool/gasolina e a posterior comparação com os efeitos tóxicos da combustão da gasolina e da mistura chumbo/gasolina. (BÖHM et al., 1983: MASSAD et al.,1985; SALDIVA et al., 1985; MASSAD et al., 1986; LOFTI et al., 1990; MASSAD et al., 1993).

A potencial gravidade da situação foi o suficiente para que o LPAE, enveredasse por um novo caminho de pesquisa, ou seja, estimar os efeitos da poluição do ar causada pela queima de biomassa. Com efeito, foi desenhado um estudo ecológico de séries temporais utilizando a variação diária de um marcador de poluição e seus efeitos sobre um marcador diário de morbidade respiratória, e esse estudo é o primeiro em toda a literatura relacionando os efeitos agudos da queima de cana-de-açúcar e morbidade respiratória.

\subsection{O Presente Estudo}

O presente estudo mostrou que a fuligem produzida pela queima da cana-de-açúcar tem influência sobre a saúde dos habitantes de Araraquara. Variações diárias no peso do sedimento decorrente da fuligem 
da cana mostravam-se significativamente associados a variações diárias nas inalações. Essa associação resistiu aos fatores confundidores (fim de semana, temperatura, sazonalidade).

Houve algumas dificuldades para viabilizar o estudo. Avaliar os poluentes na atmosfera não é uma atividade constante em Araraquara. Diferentemente do que ocorre na região metropolitana de São Paulo, onde a CETESB faz medições diárias de vários poluentes e em vários pontos da cidade, em Araraquara foram realizadas medições em 1986 e, posteriormente, somente no ano de 1997.

Essas medições, mesmo que esporádicas, já sinalizaram que havia um aumento do material particulado na atmosfera da cidade durante o período da queima de cana, quando comparado ao período da entressafra.

A necessidade de um marcador diário de poluição encaminhou ao recipiente plástico e à coleta da fuligem por sedimentação simples. $\mathrm{O}$ método, que a princípio pode ser considerado rudimentar e com limitações, uma vez que a mensuração do material particulado se faz através de partículas grossas, mostrou-se, entretanto, bastante prático, útil, de baixo custo e eficaz. Não há razões para considerar que o indicador de poluição utilizado, ou seja, as medidas diárias da fuligem (partículas grossas) por sedimentação simples não tenham proporcionalidade com as partículas finas e ultrafinas emitidas pela combustão da biomassa. OSTRO 1993; OSTRO; 
CHESTNUT, 1998), já haviam relatado proporcionalidade entre TSP e $\mathrm{PM}_{10}$, e entre $\mathrm{PM}_{10}$ e $\mathrm{PM}_{2,5}$. MORAWSKA et al (1998); MORAWSKA; THOMAS (1999); WHO (1999); FRANCO (2001), demonstraram o significante percentual de partículas finas e ultrafinas emitidas, que ocorre durante a queima de biomassa. Conclui-se que a mensuração do peso do sedimento proveniente da fuligem da cana-de-açúcar (partículas grossas) é um indicador que pode ser considerado eficaz para avaliar indiretamente a maior ou menor quantidade de emissão das partículas inaláveis durante a queima dos canaviais.

A correlação quase perfeita encontrada entre os dois pontos de medidas indica uma deposição homogênea da fuligem na cidade de Araraquara. Esse achado foi corroborado por FRANCO (2001), em estudo que utilizou quatro pontos na cidade para mensuração do material particulado fino e ultrafino. A quantidade do material particulado nos quatro pontos apresentou-se altamente correlacionada e estatisticamente significante. A convergência dos resultados obtidos pelos dois trabalhos permite-nos propor que futuros trabalhos envolvendo material particulado proveniente da queima de cana-de-açúcar na cidade de Araraquara utilizem somente um ponto de observação, ou que estudos para a instalação de equipamentos de monitoramento dos poluentes do ar, especialmente partículas inaláveis, leve em consideração a utilização de apenas um local. 
A escolha de dados que proporcionassem um indicador de morbidade adequado trouxe algumas dificuldades. Araraquara era e é considerada uma cidade com uma boa infra-estrutura em termos de saúde. Em 1995, a Rede de Saúde oferecia à população atendimento médico em nível primário, secundário e terciário, assim distribuídos:

Nível Primário

- 14 Centros Municipais de Saúde

- Dois Prontos Socorros Municipais

- Ceama (ambulatório do funcionalismo público estadual)

- Unamos (ambulatório dos alunos e professores da Unesp )

- Sesa (Serviço Especial de Saúde - Faculdade de Saúde Pública da USP)

- lamspe (Instituto de Assistência Médica dos Servidores Públicos do Estado de São Paulo

Nível Secundário

- Ambulatório NGA-3

- Centro Regional de Reabilitação

- Umed - Unidade de Diagnóstico 
Nível Terciário

- Hospital Santa Casa de Misericórdia

- Hospital Beneficência Portuguesa

- Hospital Gota de Leite (Maternidade).

- Hospital Caibar Schutel (Psiquiátrico)

Por sua vez, a rede privada disponibilizava atendimento em dois locais:

- Hospital São Paulo

- Instituto Araraquarense de Psiquiatria

Em que pese o modelo de saúde acima descrito, atingir plenamente os objetivos traçados, com relação a um bom atendimento médico à população, não encontramos na rede pública uma sistematização dos registros médicos e de procedimentos que viabilizassem a escolha de um marcador de saúde que atendesse os objetivos do estudo. Havia dificuldades na obtenção de dados nos serviços de atendimento aos pacientes ambulatoriais, e, da mesma forma, nos hospitais, com relação à patologia que determinava a internação do paciente. Havia distorções na utilização da Classificação Internacional de Doenças (CID), no preenchimento da Autorização de Internação Hospitalar (AlH), na uniformidade dos procedimentos médicos e na terapêutica utilizada, na qual inexistia um protocolo que uniformizasse a conduta. 
DOCKERY; POPE (1994) comentam que patologias que mereçam internações são seletivas, pois atingem somente pacientes com doenças graves, e esse fato deve ser constantemente lembrado em estudos epidemiológicos quando se calcula a magnitude dos efeitos dos poluentes sobre a saúde, avaliados em termos de internações hospitalares. Dados menos seletivos, como, por exemplo, atendimentos em prontos-socorros ou ambulatórios devem ser mais abrangentes e mostrar efeitos de maior magnitude.

Os fatos anteriormente relatados nos levaram a utilizar dados de atendimentos na unidade de emergência em um hospital privado, que atendia usuários de uma organização de prestação de serviços médicos (Hospital São Paulo). Isso nos permitiu avaliar uma população razoavelmente homogênea, do ponto de vista sócio-econômico.

A definição da terapêutica inalatória como marcador de morbidade nos pareceu adequada, uma vez que esse tipo de terapêutica é utilizado em unidades de emergência objetivando o tratamento de afecções respiratórias agudas. $O$ dados das inalações foram conseguidos de forma retrospectiva, através de pesquisa em prontuários, o que garantiu a total isenção da prescrição, seja por parte dos médicos plantonistas, seja por parte do pesquisador. 


\subsection{Desenho do Estudo}

No estudo, a unidade de observação é um conjunto de indivíduos, no caso os habitantes da cidade de Araraquara, e não cada indivíduo em particular. A exposição à poluição é caracterizada pela exposição média da cidade, já que seria impossível avaliar a exposição à qual cada indivíduo é particularmente submetido, ou seja, considerou-se adequado um estudo ecológico de séries temporais. Originariamente, o estudo ecológico foi utilizado para gerar hipóteses a serem investigadas em estudos a nível individual, ou para avaliar o impacto de programas de intervenção sobre populações. O estudo ecológico apresenta como vantagens o baixo custo e o menor tempo utilizado para execução, quando comparado com o estudo de coorte ou caso-controle, uma vez que, geralmente, os dados necessários à realização desses estudos são colhidos para outras finalidades e, depois, disponibilizados para a pesquisa científica. Porém, a possível falta de critérios científicos rigorosos no momento da coleta original dos dados muitas vezes leva à impossibilidade do seu uso. Os estudos ecológicos são passiveis de outros vieses importantes. Pelo fato de não utilizarmos dados individuais na análise, a relação entre a exposição aos poluentes e os efeitos sobre a saúde calculada em diferentes comunidades, pode não refletir o nível de associação entre a exposição e os efeitos em um individuo. Diferentemente de um estudo de coorte, no qual a unidade de observação é o individuo, não são conhecidas as proporções de expostos e doentes, não expostos e doentes, expostos e não doentes e não expostos e não doentes. 
Apenas os valores marginais, como o total de expostos e não expostos, e de doentes e não doentes, são acessíveis (MORGENSTERN, 1982, 1995).

Os estudos de séries temporais entre os tipos de estudos ecológicos são menos susceptíveis a esses vieses. A evidência causal de um determinado risco agregado pode ser fortalecido, já que as observações são feitas em dois ou mais pontos do tempo diferentes, diminuindo a probabilidade da associação de interesse ser considerada espúria (DOCKERY: POPE, 1994; FLETCHER et al., 1996). Outro ponto que melhora o poder desse tipo de desenho de estudo epidemiológico é o uso de modelos de regressão cada vez mais sofisticados que permitem que se controle com maior eficácia os fatores de confundimento, fatores esses que poderiam interferir nas estimativas. (PEREIRA, 1999).

Esses aprimoramentos metodológicos nos estudos de séries temporais têm possibilitado indicar a presença de relação causa e efeito entre os poluentes do ar e a saúde humana (POPE et al., 1992; SCHWARTZ, 1994a).

MORGENSTERN (1995) refere que a relação temporal sustenta a conclusão de uma relação causal, mesmo quando ambos, o resultado (por exemplo, o número de mortes não acidentais em uma cidade durante um dia) e a exposição (por exemplo, concentração diária de poluentes), sejam índices da comunidade, e não individuais. 
O estudo visa comparar a cidade de Araraquara com si mesma, ao longo do tempo, verificando a variação diária do peso do sedimento proveniente da fuligem da queima da cana-de-açúcar na atmosfera e comparando esses dados com a variação diária de um indicador de agravo à saúde, a inalação, no serviço de emergência do Hospital São Paulo, independentemente de outros fatores, tais como clima e sazonalidade. Não nos foi possível determinar a patologia respiratória que determinou a terapêutica inalatória, ou mesmo a idade ou sexo do pacientes. Esses dados certamente enriqueceriam o estudo.

Existe mais uma razão para que o estudo proponha a utilização de Araraquara como controle de si mesma. Quando se objetiva comparar populações distintas a nível ecológico vários fatores podem distorcer os resultados observados. Se tentássemos comparar Araraquara com qualquer outra cidade fora da zona de influência da queima da cana-de-açúcar, deveríamos escolher uma cidade que se assemelhasse a Araraquara em termos de clima, características demográficas, sistema de saúde, nível socioeconômico, educação, etc. Encontrar cidades tão similares não é uma tarefa fácil. O difícil, nesse caso, seria atribuir unicamente à queima da cana as eventuais diferenças observadas entre as cidades, visto que os fatores acima citados podem alterar de forma significativa a história de morbidade de uma comunidade. Ao utilizar um estudo de série temporal, Araraquara passa a ser o seu próprio controle, pois as variações ocorridas hoje serão comparadas com aquelas que ocorreram ontem, ou anteontem, na mesma 
cidade. Ao compararmos Araraquara com si mesma, ao longo de um curto período de tempo (aproximadamente cem dias), podemos imaginar que as condições sociais, médicas e econômicas da cidade se mantenham razoavelmente constantes. Assim sendo, é muito pouco provável que certas variáveis influenciadoras de doenças respiratórias - o tabagismo, por exemplo - exibam colinearidade com a poluição atmosférica. Falando de outra forma, é pouco provável que as pessoas de uma população fumem mais quando a poluição aumenta, ou que exista uma sincronia entre poluição atmosférica e deficiência do sistema de saúde.

A avaliação inicial dos resultados através do Coeficiente de Correlação de Pearson mostrou uma associação positiva e significativa entre o peso do sedimento e o numero de inalações, além de uma correlação negativa e significativa entre a temperatura mínima e o peso do sedimento.

Adotamos os modelo de regressão para assegurar a validade dos resultados. A sofisticação dos modelos de regressão permite o controle mais eficaz dos fatores de confundimento e de colinearidade entre as variáveis, o que eventualmente poderia interferir na análise dos dados. Colinearidade é a presença de grande correlação entre as variáveis explicativas, o que eventualmente pode traduzir-se em um resultado incorreto da correlação entre a variável resposta e a variável explicativa de interesse (ZAR, 1996). Entre os modelos de regressão disponíveis optamos pelo modelo de regressão de Poisson uma vez que a nossa variável resposta (inalação) era um evento de contagem, além do que esse modelo de regressão nos possibilita avaliar o risco 
relativo da exposição ao poluente. O modelo aditivo generalizado (MAG) foi utilizado pelo fato de termos em nosso modelo variáveis explicativas que apresentavam relações lineares (peso da fuligem e fim de semana) e outras não lineares (sazonalidade e temperatura). Para modelar as relações não lineares foi utilizada a curva de alisamento.

A relação entre o dia da exposição ao poluente e a ocorrência dos efeitos sobre a saúde foi controlada com a utilização da concentração média dos poluentes nos dias anteriores ao evento. O resultado evidenciando uma defasagem de dois dias mostra tratar-se de um efeito agudo.

\subsection{Critérios de Causalidade}

Segundo ANDRÉ (2000), a inferência causal é o ponto crucial nos estudos epidemiológicos. É necessário assegurar que haja uma relação causal entre exposição ao poluente e efeito sobre a saúde. Com o intuito de assegurar que determinado estudo epidemiológico produziu uma causalidade entre exposição aos poluentes e efeitos sobre a saúde, Sir Austin Hill, em 1965, propôs critérios que, se respeitados, reforçariam a credibilidade de um estudo epidemiológico.

- Força na associação: uma associação forte que permanece estatisticamente significante mesmo após controle dos elementos confundidores, provavelmente seria uma associação causal entre os poluentes e efeitos sobre a saúde. 
- Consistência: a consistência é evidenciada quando se observa resultado similar em vários estudos, mesmo sendo observados por diferentes pesquisadores e sob diferentes circunstâncias.

- Especificidade: a causa deve estar associada a uma patologia ou a um grupo de especifico de doenças: por exemplo, a poluição do ar está freqüentemente associada a doenças respiratórias.

- Temporalidade na associação: a exposição ao agente agressor deve preceder a agressão.

- Gradiente biológico: é necessária a presença de uma associação dose-dependente entre a exposição e os efeitos, ou seja, quanto maior a exposição maior os efeitos.

- Plausibilidade biológica: é sugerida pelos conhecimentos prévios sobre a fisiopatologia da doença e os mecanismos pelos quais pode causar efeitos adversos. Estudos toxicológicos em animais têm auxiliado o entendimento de alguns desses processos.

- Coerência: significa que a relação causal não pode entrar em conflito com a história natural da doença; ou seja, provavelmente o aumento dos níveis de poluentes causaria ou agravaria doenças cardiorrespiratórias

- Confirmação experimental por observação: uma vez demonstrada a associação entre exposição e efeito, a intervenção para controle da exposição resultaria na resolução ou atenuação do efeito observado. 
- Julgamento por analogia: se poluentes ambientais tem mostrado, ao nível experimental, serem capazes de induzir alterações imunológicas e inflamatórias no trato respiratório de animais, esses poluentes devem induzir alterações similares na raça humana.

$\mathrm{Na}$ análise do presente estudo avaliou-se a concordância com os requisitos propostos por HILL (1965).

- Força na associação: O Coeficiente de Correlação de Pearson mostrou uma associação positiva e significante entre o peso do sedimento e a inalação $(0,36, P<0,01)$. Essa associação mantevese estatisticamente significante mesmo após controle dos elementos confundidores (temperatura, fim de semana, sazonalidade), utilizando o Modelo de Regressão de Poisson: IC95\% (0,00862; 0,00007, 0,01717).

- Consistência: A maior quantidade de estudos relacionando visitas a unidade de emergência e poluição atmosférica está centrada nos efeitos tóxicos do material particulado proveniente de combustíveis fósseis. WITTEMORE et al. (1980), em estudo realizado em Los Angeles, EUA, entre 1972 e 1975, demonstraram que havia um aumento de $1,4 \%$ no atendimento de asma em crianças, relacionado a um aumento de $10 \mu \mathrm{g} / \mathrm{m} 3$ no $\mathrm{PM}_{10}$. SAMET et al. (1981), em estudo realizado em Steubenville, EUA, no período entre 1974 e 1977, demonstraram uma forte associação entre 
consultas de urgência por doenças respiratórias e níveis de "TSP" e SO2. SCHWARTZ et al. (1993), na região de Seatle, EUA, encontraram um aumento de 3,4\% nas consultas de urgência por crise asmática, associado a uma elevação de $10 \mu \mathrm{g} / \mathrm{m} 3$ na concentração de $\mathrm{PM}_{10}$, sendo que a concentração de poluente nunca excedeu $70 \%$ do nível limite diário considerado como tolerável pela "USEPA". SUNYER et al. (1993), em Barcelona, Espanha, relatam que as consultas de urgência por doença pulmonar obstrutiva crônica aumentaram cerca de 1,7\% em associação à elevação de $10 \mu \mathrm{g} / \mathrm{m} 3$ de $\mathrm{PM}_{10}$. LIN (1997), em São Paulo, relata um acréscimo nos atendimentos de crianças por patologia respiratória, de 3,9\% para um aumento de $10 \mu \mathrm{g} / \mathrm{m}^{3}$ de PM10. DELFINO et al. (1997), em Montreal, Canadá, encontraram uma forte associação entre poluição do ar e visitas a emergência em pacientes com idade acima de 64 anos. A associação era positiva para uma concentração média de $\mathrm{PM}_{10}$ de $21,7 \mu \mathrm{g} / \mathrm{m}^{3}$, e uma concentração média de $\mathrm{PM}_{2,5}$ de $12,2 \mu \mathrm{g} / \mathrm{m}^{3}$. MEDINA et al. (1997), em Paris, França, relatam uma significante associação entre visitas aos consultórios médicos por asma e concentração média de $\mathrm{PM}_{13}$ de $25 \mu \mathrm{g} / \mathrm{m} 3$, e concentrações máxima diária de 95 $\mu \mathrm{g} / \mathrm{m3}$. HAJAT et al. (1999), em Londres, Inglaterra, relatam associação significante entre níveis médios de $\mathrm{PM}_{10}$ de $28,2 \mathrm{ug} / \mathrm{m} 3$ e visitas a consultórios médicos por asma em crianças e adultos jovens. NORRIS et al. (1999; 2000), em Seattle, EUA, encontraram 
uma forte associação entre visitas a emergência, causadas por crise de asma em crianças e adultos jovens, com médias de $\mathrm{PM}_{10}$ de $21,7 \mu \mathrm{g} / \mathrm{m}^{3}$ e de $\mathrm{PM}_{2,5}$ de $12 \mu \mathrm{g} / \mathrm{m} 3$. A exacerbação da crise de asma era evidente mesmo quando as concentrações de $\mathrm{PM}_{2,5}$ estavam substancialmente abaixo do nível preconizado pela "USEPA". TOLBERT et al. (2000), em Atlanta, EUA, relatam uma significante associação entre concentrações máximas de $\mathrm{PM}_{10}$ de $105 \mu \mathrm{g} / \mathrm{m} 3$ e visitas pediátricas à emergência. LIPSETT et al. (1997), em Santa Clara na Califórnia, EUA, relatam aumento, em três hospitais da cidade, no número de atendimentos no setor de emergência por crise da asma brônquica associado à elevação em níveis do $\mathrm{PM}_{10,}$, atingindo todas as idades nos invernos entre 1988 e 1992. Os autores encontraram níveis de $\mathrm{PM}_{10}$ que variaram entre 09 e 165 ug/m3 com uma média de 61,2 ug/m3. A fonte do material particulado era proveniente da queima de madeira utilizada para aquecimento. Essa associação tornava-se mais significante quando associada com temperatura baixa. A relação entre o aumento do nível de poluentes por queima de biomassa a céu aberto e o aumento de visitas às unidades de emergência, foi descrita por DUCLOS (1990), na Califórnia, EUA; CHEW (1995), em Singapura; LONG (1998) em Winnipeg, Canadá; DAWUD (1998); KUNII (1998) na Indonésia; PHOMBOON (1998) na Tailândia. Temos a considerar que os episódios relatados acima, exceto o de LONG, dizem respeito a incêndios florestais.. O trabalho de LONG, no 
Canadá, mostra que a queima da biomassa (palha e restos agrícolas), elevou o nível médio histórico de $\mathrm{PM}_{10}(15-40 \mu \mathrm{g} / \mathrm{m} 3)$. Durante duas semanas a comunidade conviveu com níveis significativamente mais elevados $(80-110 \mu \mathrm{g} / \mathrm{m} 3)$. Apesar da semelhança entre o estudo de LONG e o presente estudo, quanto a natureza da biomassa queimada (palha), o tempo de exposição da população aos poluentes foi nitidamente diferente. Os estudos de SCHWARTZ (1993), DELFINO (1997), NORRIS (1999, 2000), HAJAT (1999) mostraram associação entre visitas aos serviços de emergência apesar de concentrações de $\mathrm{PM}_{10}$ e $\mathrm{PM}_{2,5}$. estarem abaixo do nível considerado como aceitável pelos padrões de qualidade do ar da "USEPA". Outros estudos relatam associação entre admissões hospitalares, ou visitas a emergência por patologias respiratórias agudas, e níveis médios de $\mathrm{PM}_{10}$ constantemente abaixo de 50ug/m3: MOOLGAVKAR et al. (1997) em Minneapolis; SHEPPARD et al. (1999) em Seattle; NAUMBERG; BASU (1999) em Los Angeles; GWYIN et al. (2000) em Buffalo; LINN et al. (2000) em Los Angeles. Interessante comentar a particularidade única da queima da biomassa nas regiões canavieiras, uma vez que a população fica exposta durante o período da colheita (aproximadamente seis meses ao ano), a níveis de material particulado continuadamente mais elevado, quando comparado ao período da entressafra. (CETESB, 1986; 1999). 
- Especificidade de associação: O estudo relaciona a poluição do ar com doenças respiratórias, associação essa corroborada pela extensa literatura já citada.

- Temporalidade da associação: O estudo mostra que a melhor associação entre a exposição ao material particulado e o efeito sobre a população ocorreu com uma defasagem de dois dias, como visto na análise com médias móveis do poluente.

- Gradiente Biológico: O estudo mostra que há uma associação dosedependente entre o peso do sedimento e o número de inalações. Uma elevação de $10 \mathrm{ug} / \mathrm{m} 3$ no peso do sedimento associa-se a um risco relativo de inalação de $9 \%$. O gradiente biológico torna-se mais evidente quando são ajustados modelos contendo variáveis indicadoras para categorias das concentrações dos poluentes em lugar das variáveis continuas, com o objetivo de melhor visualizar o efeito da poluição à medida que a sua concentração aumenta. $O$ quarto quartil (peso do sedimento acima de $17 \mathrm{mg}$ ) apresenta uma significante associação com a inalação, mostrando um risco relativo de $20 \%$ em relação ao primeiro quartil (1.03-1.39).

- Plausibilidade biológica: Os resultados do estudo são referendados por estudos toxicológicos que encontram relação entre material particulado e seus efeitos sobre o sistema respiratório (BÖHM et al, 1983, 1989; SALDIVA et al., 1992; PEREIRA et al., 1995) 
- Coerência: O estudo mantém coerência com outros estudos que relacionam elevação nos níveis de material particulado e aumento no número de atendimentos em serviços de emergência causado por patologia respiratória

- Confirmação experimental por observação: Não há no momento, em Araraquara, a possibilidade de se conduzir um experimento de intervenção, porém, não podemos deixar de citar o episódio do Vale de Utah (POPE, 1989), onde uma greve fechou uma velha siderúrgica, a maior fonte de material particulado na cidade, e, tanto os níveis de material particulado como as admissões pediátricas nos hospitais foram reduzidas à metade.

- Julgamento por analogia: $\mathrm{O}$ material particulado avaliado no estudo, tem mostrado, a nível experimental, capacidade de produzir alterações no sistema imune e nas funções respiratórias de animais (HATCH et al., 1985; SALDIVA et al., 1985, 1992; LEMOS et al., 1992; PEREIRA et al., 1995). Essas alterações podem ser semelhantes em seres humanos, sempre lembrando as diferenças entre animais de laboratórios e seres humanos quanto as respostas dos diferentes organismos às agressões. 
A análise dos itens propostos por HILL (1965) robustecem a causalidade entre a poluição atmosférica decorrente da queima de cana e agravos a saúde. OSTRO (1993) afirma que inferir causalidade a partir de associações estatísticas é um processo informal, dependente de critérios. Ainda assim, os resultados de nosso trabalho sugerem uma sólida relação causa e efeito, merecendo, no entanto, a realização de novos estudos para tratar a reprodutibilidade dos resultados, não só em Araraquara, como também em outras cidades localizadas em regiões canavieiras.

\subsection{Aspectos Sociais}

A prática da despalha da cana-de-açúcar pela queima é corrente no Estado de São Paulo, acompanhando exemplo de outras unidades da federação, e de outros países do mundo, tais como Austrália, África do Sul, Estados Unidos, Argentina, Bolívia Colômbia, México e Venezuela. No entanto, essa prática vem sendo contestada por membros do Ministério Público Estadual, através de ações judiciais, e pela ação das comunidades preocupadas com os efeitos dessa prática agrícola sobre a saúde, a segurança, o meio ambiente e a qualidade de vida nos meios urbanos próximos às plantações. Ela é questionada, também, pelos técnicos de governo da área ambiental, por seus danos ambientais, particularmente a poluição do ar e riscos de incêndios e desmatamentos. Cumpre salientar, no entanto, que a lavoura de cana-de-açúcar, apesar de temporária, emprega elevado volume de trabalhadores nos meses da colheita no estado, 
perfazendo uma taxa de 234.007 EHA (equivalentes homens-ano) em 1998, segundo dados da Fundação Sistema Estadual de Análise de Dados (SEADE), o que a tornou a principal fonte de demanda de força de trabalho agrícola naquele ano no Estado de São Paulo. Entretanto, é importante destacar que os dados dos dois últimos censos agropecuários do IBGE mostram um declínio no pessoal ocupado em atividades agrícolas nos estabelecimentos do Estado de São Paulo, sendo que, de 1.357.113 pessoas, em 31 de dezembro de 1985, passou para 914.954, em 31 de dezembro de 1995. Essa diferença está relacionada com o declínio das lavouras e ao processo de modernização da produção, que provoca a expulsão da mão-de-obra. Desde a década de 1960, a agricultura do Estado de São Paulo vem-se modernizando e seus coeficientes de mão-de-obra estão se reduzindo. Dados do SEADE demonstram que houve em 1998 uma pequena queda na demanda da mão-de-obra na cultura da cana-de-açúcar, mesmo com o crescimento da área cultivada, vista como resultado dos impactos da colheita mecânica. O Decreto Estadual $N^{0} 42.056$, de 06 de agosto de 1997, que determinou a eliminação gradual da despalha por queima no Estado de São Paulo, em um prazo máximo de 8 a 15 anos, dependendo das características da plantação, pode gerar graves problemas no emprego de mão-de-obra no setor agrícola, daí existir forte resistência dos sindicatos de trabalhadores rurais à mecanização. Deve-se reconhecer, no entanto, que a colheita mecânica da cana-de-açúcar vem crescendo nos últimos anos e apresenta alguns benefícios de ordem ambiental. No sistema de colheita mecânica a palha deixa de ser queimada, evitando a emissão de 
poluentes atmosféricos, e as folhas secas, ponteiros e folhas verdes cortados são lançados sobre a superfície do solo, formando uma camada de material que, ao degradar-se, constitui fonte de nutrientes para o solo e para a cultura de cana-de-açúcar. Por outro lado, a adoção da colheita mecanizada na região canavieira poderá alterar todo o sistema de produção da cana-de-açúcar, tradicionalmente conhecido pelo grande número de empregos gerados no período das safras. Estima-se que somente para as áreas potencialmente mecanizáveis, o número de desempregados somaria cerca de 90.000, apenas no Estado de São Paulo, caso a prática de queima de cana fosse substituída pela mecanização da cana crua. A isso se soma 0 atual quadro político econômico social do país, com taxas crescentes de desemprego, em que certamente haveria dificuldades de absorção desse grande contingente de trabalhadores com pouca qualificação profissional. (FURRIELA, 2001) 
6. CONCLUSÕES 
O estudo conclui que:

1- Há uma associação causal entre o material particulado decorrente da queima de plantações de cana-de-açúcar e um indicador de morbidade respiratória na cidade de Araraquara.

2- $\quad$ A relação entre poluição atmosférica e efeitos sobre a saúde da população mostrou ter um efeito agudo após curto período de exposição, com um tempo de defasagem de dois dias.

3- $\quad$ A associação causal é dose-dependente. 


\section{SUGESTÕES}


1. O método de avaliação do material particulado mostrou-se uma ferramenta útil, porém estudos futuros deveriam mensurar as partículas inaláveis.

2. Estudos futuros deveriam ampliar a faixa da população estudada utilizando na amostragem diferentes níveis socioeconômicos.

3. Estudos futuros deveriam ampliar o tempo de avaliação utilizando estudos de coorte em população de risco, ou seja, em pacientes portadores de asma brônquica, portadores de doença pulmonar obstrutiva crônica e portadores de doenças cardiovasculares.

4. Estudos futuros deveriam utilizar o material particulado proveniente da queima da cana-de-açúcar para a realização de estudos toxicológicos em animais ou preparações celulares e posteriormente comparar esses achados com os resultados de estudos semelhantes realizados com o material particulado proveniente de combustíveis fósseis. 
8. REFERÊNCIAS BIBLIOGRÁFICAS 
AKAIKE, $H$. Information theory and an extension of the maximum likelihood principal. In: PETROV B.N, CSAKI, F., ed. SECOND INTERNATIONAL SYMPOSIUM ON INFORMATION THEORY. Budapest: Akademiai Kaiado, 1973.

ALBALAK, R.; FRISANCHO, AR.; KEELER, G.J. Domestic biomass fuel combustion and chronic bronchitis in two rural Bolivian villages. Thorax, v. 54, p. 1004-8, 1999.

AMERICAN LUNG ASSOCIATION. Selected key studies on particulate matter and health: 1997-2001. Disponível na Internet: < http: // www.lungusa.org >. Acesso em: março 2001.

ANDRE, P.A; BRAGA, A.L.F.; LIN, C.A.; CONCEIÇÃO, G,M.S.; PEREIRA, L.A.A.; EL KHOURY MIRAGLIA, S.G.; BHÖN, G.M. Environmental epidemiology applied to urban atmospheric pollution: a contribution from the Experimental Air Pollution Laboratory (LPAE). Cad. Saúde Pública, v. 16, p. $619-28.2000$

ANDREAE, M.O. Biomass burning: its history, use, distribution and its impact on environmental quality and global climate In: LEVINE, J.S. ed. Global Biomass Burning. Cambridge, The MIT Press, 1991. cap 1, p. 3-21.

ANDERSON, H.R. Respiratory abnormalities and ventilatory capacity in a Papua New Guinea island community. Am. Rev. Respir. Dis., v. 114, p. 537-48, 1976. 
ANDERSON, H.R. Chronic lung disease in the Papua New Guinea highlands. Thorax, v. 34, p. 647-53, 1979.

ANDERSON, H.R.; PONCE, DE LEON, A.; BLAND, JM.; BOWER, J.S.; STRACHAN, D.P. Air pollution and daily mortality in London: 19871992. Br. Med. J., v. 312, p. 665-9, 1996.

ANDERSON, H.R. Health effects of air pollution episodes. In: HOLGATE, S.T.; SAMET J.M.; KOREN H.S.; MAYNARD, R.L., ed. Air pollution and health. San Diego, Academic Press, 1999. cap. 21, p.461-82.

ARMSTRONG, J.R.; CAMPBELL, H. Indoor air pollution exposure and lower respiratory infections in young Gambian children. Int. J. Epidemiol., v. 20, p. 424-9, 1991.

ARTAXO, P.; YAMOSOE, M.A.; MARTINS, J.V.; KOCINAS, S.; CARVALHO, S.; MAENHAUT, W. C. Case study of atmospheric measurements in Brazil: Aerosol emissions from Amazon basin fires. In: CRUTZEN, P.J.; COLDAMMER, J.G., ed. Fire in the environmental. Chichester, John Wiley \& Sons, 1993. cap. 9, p. 139-155.

ASSOCIAÇÃO DA INDUSTRIAS DE AÇÚCAR E DE ÁLCOOL DO ESTADO DE SÃO PAULO. Álcool, história de um combustível sustentável. São Paulo, Editora Segmento, 1997.

AZIZI, B.H.; ZULFKFLI, H.I.; KASIM, S. Indoor air pollution and asthma in hospitalized children in a tropical environment. J. Asthma, v. 32, p. 4138, 1995.

BACHAROVA, L.; FANDAKOVA, K.; BRATINKA, J.; BUDINSKA, M.; BACHAR, J.; GUD-ABA, M. The association between air pollution and the daily number of deaths: Findings from the Slovak Republic contribution to the APHEA project. J. Epidemiol. Community Health, v. 50, p. S19-S21, 1996. Supplement 1. 
BALLESTER, F.; CORELLA, D.; PEREZ-HOYOS, S.; SAEZ, M.; HERVAS, A., Air pollution and mortality in Valencia, Spain: a study using the APHEA methodology. J. Epidemiol. Community Health, v.50, p.52633, 1996.

BALleSteR, F.; CORELlA, D.; PEREZ-HOYOS, S.; SAEZ, M.; HERVAS, A. Mortality as a function of temperature. A study in Valencia, Spain, 1991-1993. Int. J. Epidemiol., v.26, p. 551-61, 1997.

BASALDI, O.V. Demanda da força de trabalho na agricultura paulista no período de 1990-1997. Informações Econômicas, v.28, p. 19-31, 1998.

BASCOM, R.; BROMBERG, P.A.; COSTA, D.A.; DEVLIN, R.; DOCKERY, D.W.; FRAMPTON, M.W.; LAMBERT, W.; SAMET, J.M.; SPEIZER, F.E.; UTELL, M. Health effects of outdoor pollution. Am. J. Respir. Crit. Care Med., v. 153, p. 3-50, 1996.

BARNES, A. C. The sugar cane. New York, Interscience Publishers, 1964.

BATES, D.V. The heath effects of air pollution. J. Respir. Dis., v. 1, p. 29-37, 1980.

BATES, D.V.; BAKER-ANDERSON, M.; SIZTO, R. Asthma attack periodicity: A study of hospital emergency visits in Vancouver. Environ. Respir., v. 51, p. 51-70, 1990.

BATES, D.V.; SIZTO, R. Relationship between air pollution levels and hospital admissions in Southern Ontario. Can. J. Public Health, v. 74, p. 117-22, 1983.

BEHERA, D.; DASH, S.; YADAV, S.P. Carboxyhaemoglobin in women exposed to different cooking fuels. Thorax, v. 46, p. 344-46, 1991. 
BEHERA, D.; JINDAL, S.K.; MALHOTA, H.S. Ventilatory function in nonsmoking rural Indian women using different cooking fuels. Respiratory, v. 61, p. 89-92, 1994.

BETCHLEY, G.; KOENING, J.Q.; VAN, BELLE, G.; CHECKOWAY, H.; REINHARDT, T. Pulmonary function and respiratory symptoms in forest firefighters. Am. J. Ind. Med., v. 31, p. 503-9, 1997.

BLAKBURN, F. Sugar cane. London, Longman, 1984. p. 1-32: The origin and history of the sugar cane.

BLIMBLESCOMBE, P. Air pollution and health history. In: HOLGATE, S. T.; SAMET J. M.; KOREN H. S.; MAYNARD, R. L., ed. Air pollution and health. San Diego, Academic Press, 1999. cap.2 , p. 5-18

BÖHM, G.; SALDIVA, P.H.N.; GOUVEIA, M.; PASQUALUCCI, C.A. ; CARDOSO, L.M.N.; CALDEIRA, M.P.R.; CALHEIROS, D.F. Comparative Toxicity of Alcohol and Gasoline-Fueled Automobile Exhaust Fumes. In; HAYES, W., SBEKK, R.C., MIYA, T.S., ed. Development of the science and practice of toxicology. Amsterdam, Elsevier Science, 1983. p. 479-82.

BÖHM, G. M.; SALDIVA, P.H.N.; PASQUALUCCI, C.A. ; MASSAD, E.; MARTINS,M.A.; ZIN, W.A.; CARDOSO, W.V. ; CRIADO, P.M.P.; KOMATSUZAKI, M.; SAKAI, R.S. ; NIGRI, E.M. ; LEMOS, M.; CAPELOZZI, V.D. ; CRESTANA, C. ; SILVA, R. Biological effects of air pollution in Sao Paulo and Cubatão. Environ. Res. , v. 49, p. 208- 16, 1989.

BORJA-ABURTO, V.H.; LOOMIS, D.P.; BANGDIWALA, S.I.; SHI, C.M.; RASCON-PACHECO, R.A. Ozone, suspended particulates, and daily mortality in Mexico City . Am. J. Epidemiol., v.145, p. 258-68, 1997. 
BOY, E.; BRUCE, N.; DELGADO, H. Birth weight and exposure to kitchen wood smoke during pregnancy. Child and adolescent health. Geneva, World Health Organization, 1999.

BRAGA, A.L.F. Quantificação dos efeitos da poluição do ar sobre a saúde da população pediátrica da Cidade de São Paulo e proposta de monitorização. São Paulo, 1998. 225p. Tese (Doutorado) Faculdade de Medicina, Universidade de São Paulo.

BRAGA, A. L..F.; CONCEIÇÃO, G.M.S.; PEREIRA, L.A.A.; KISHI, H.; PEREIRA,J.C.R.; ANDRADE, M.F.; GONÇALVES, F.L.T.; SALDIVA, P.H.N., LATORRE, M.R.D.O. Air pollution and pediatric respiratory hospital admissions in Sao Paulo, Brazil. J. Environ. Med., v.1, p.95102, 1999.

BRAGA A.L.F., SALDIVA, P.H.N.; PEREIRA, L.A.A.; MENEZES, J.J.C.; CONCEIÇÃO, G.M.S.; LIN, C.L.; ZANOBETTI, A.; SCHWARTZ, J.; DOCKERY, D.W. Health effects of air pollution exposure on children an adolescents in Sâo Paulo, Brazil. Pediatr. Pulmonol., v. 31, p. 106-13, 2001.

BRANDÃO A. Cana-de-açúcar, álcool e açúcar na história e no desenvolvimento social do Brasil. Brasília, Horizonte Editora, 1984 p. $55-6$.

BRAUER, M.; HISHAM-HASHIM, J. Indonesia Fires: Crisis and Reaction. Environ. Sci. Technol., v. 32, p. 404-7, 1998.

BRAUN-FAHRLANDER, C.; ACKERMANN-LEIBRICH, U.; SCHWARTZ, J.; GNEHM, H.P.; RUTISHAUSER, M.; WANNER, H.U. Air pollution and respiratory symptoms in preschool children. Am. Rev. Respir. Dis., v. 145, p. 42-47, 1992.

BREYSSE, P.A. Health hazards of smoke. Journal of Forestry, v.82, p.89, 1984. 
BRUCE, N.; PEREZ-PADILLA, R.; ALBALAK, R. Indoor air pollution in developing countries: a major environmental and public health challenge. Bull. WHO, v. 78, p. 1078-92, 2000.

BRUNEKREEF, B.; DOCKERY, D.W.; KRZYZANOWSKI, M. Epidemiologic studies on short-term effects of low levels of major ambient air pollution components. Environ. Health Perpect., v.103, p. 3-13, 1995. Supplement 2.

BURNETT, R.T.; DALES, R.E.; RAIZENNE, M.E.; KREWSKI, D.; SUMMERS, P.W.; ROBERTS, G.R.; RAAD-YOUNG, M; DANN, T.; BROOK, J. Effects of low ambient levels of ozone and sulfate on frequency of respiratory admissions to Ontario hospitals. Environ. Respir., v. 65, p. 172-94, 1994.

CALVERT, J.G.; LAZRUS, A.; KOK, G.L.; HEIKES, B.J.; WALEGA, J.G.; LIND, J.; CANTRELL, C.A. Chemical mechanisms of acid generation in the troposphere. Nature, v.317, p. 27-35, 1969.

CAMPBELL, H.; ARMSTRONG, J.R.; BYASS, P. Indoor air pollution in developing countries and acute respiratory infection in children. Lancet, v. 1, p. 1012, 1989.

CARTER, J.D.; GHIO, A.J.; SAMET, J.M.; REED, W.; DELVIN, R.B. In vitro exposure of human airway epithelial cells to an air pollution particle induces IL-6, IL-8 and TNFa protein expression. Am. J. Respir. Crit. Care Med., v. 155, p. A246, 1997. Supplement.

CARVALHO, L.C.C. Os caminhos do futuro. Revista da Associação dos Municípios Canavieiros do Estado de São Paulo, v.1, p. 8-11, 2000.

CETESB. Superintendência de Qualidade Ambiental. Avaliação da qualidade do ar em Araraquara, 1986. São Paulo, CETESB, 1986.

CETESB, A cana de açúcar e o meio ambiente no estado de São Paulo. 1993. p. 45-51. 
CETESB. Relatório de qualidade do ar no Estado de São Paulo, 1996. São Paulo, CETESB, 1997a.

CETESB. Departamento de Qualidade Ambiental. Avaliação da qualidade do ar em Araraquara, Relatório Preliminar, Novembro/97. São Paulo, CETESB, 1997b.

CETESB. Departamento de Qualidade Ambiental. Resumo dos estudos em locais influenciados diretamente pelas queimadas de cana. São Paulo, CETESB, 1999. [Memorando].

COCHRANE, M.E. O grande incêndio de Roraima. Ciência Hoje, v. 27, n.157, p. 26-43, 2000.

COLLINGS, D.A.; SITHOLE, S.D.; MARTIN, K.S. Indoor woodsmoke pollution causing lower respiratory disease in children. Trop. Doctor, v. 20 , p. $151-5,1990$.

COPERSUCAR. Divisão Agronômica. Coordenadora de Agronomia. A utilização da queimada na colheita da cana-de-açúcar. São Paulo, Cooperativa Central dos produtores de Açúcar e do Álcool do Estado de São Paulo/Copersucar, 1986.

COPERSUCAR. Cana-de-açúcar e álcool. A energia que vem do sol. São Paulo, Copersucar, 1989a.

COPERSUCAR. Proálcool fundamentos e perspectivas. São Paulo, Copersucar, 1989b. p. 3-9.

CONCEIÇÃO, G.M.S. Métodos estatísticos para avaliação da associação entre poluição atmosférica e marcadores de morbi-mortalidade na cidade de São Paulo e aplicações. São Paulo, 1999. 245p. Dissertação (Mestrado) - Faculdade de Medicina, Universidade de São Paulo.. 
CHEW, F.T.; OOI, B.C.; HUI, J.K.; SAHAROM, R.; GOH, D.; LEE, B.W. Singapore's haze and acute asthma in children. Lancet, v. 346, p.1427, 1995.

CHESTNUT, L.G.; SCHWARTZ, J.; SAVITZ, D.A.; BURCHFIEL, C.M. Pulmonary function and ambient particulate matter: Epidemiological evidence from NHANES I. Arch. Environ. Health, v. 46, p. 135-44, 1991.

CRUTZEN, P.J.; ANDREAE, M.O. Biomass burning in the tropics: Impacts on atmospheric chemistry and biogeochemical cycles. Science, v. 250, p. 1669-78, 1990.

CRUTZEN, P.J.; CARMICHAEL, G.R. Modeling the influence of fires on atmospheric chemistry. In: CRUTZEN P.J.; GOLDAMMER, J.G., Fire in the Environment. Chichester, John Wiley \& Sons, 1993. cap. 6, p. 89106.

DAB, W.; MEDINA, S.; QUINEL, P.; LE MOULLEC, Y.; LeTERTRE, A.; THELOT, B.; MONTEIL, C.; LAMELOISE, P.; PIRARD, P.; MOMAS, I.; FERRY, R.; FESTY, B. Short term respiratory health effects of ambient air pollution: results of the APHEA Projects in Paris. J. Epidemiol. Community Health, v. 50, p. 42-6, 1996. Supplement 1.

DARY, O.; PINEDA, O.; BELIZAN, J. Carbon monoxide in dwelling in poor rural areas of Guatemala. Bull. Environ. Contam. Toxicol., v. 26, p. 24-30, 1981.

DAWUD, Y. Smoke Episodes and Assessment of Health impacts Related to Haze from Forest Fires: Indonesian Experience. In: HEALTH GUIDELINES FOR VEGETATION FIRE EVENTS, Lima, Peru, 1998. Geneva, WHO, 1999. p.313-33. (Background papers). 
DELMAS, R.; LACAUX, J.P.; BROCARD, D. Determination of biomass burning emission factors: methods and results. Environ. Monit. Assess., v. 38, p.181-204, 1995.

DELFINO, R.J.; MURPHY-MOULTON, A.M.; BURNETT, R.T.; E.T. A.L. Effects of air pollution on emergency room visits for respiratory illness in Montreal, Quebec. Am. J. Respir. Crit. Care Med.,v.155, p. 56876,1997 .

DENNIS, R.J.; MALDONADO, D.; NORMAN, S.; BAENA, E.; MARTINEZ, G. Woodsmoke exposure and risk for obstructive airways disease among women. Chest, v. 109, p. 115-9, 1996.

DE KONING, H.W.; SMITH, K.R.; LAST, J.M. Biomass fuel combustion and health. Bull. WHO, v. 63, p.11-26, 1985.

DE FRANCISCO, A.; MORRIS, J.; HALL, A.J.; ARMSTRONGSCHELLENBERG, J.R.; GREENWOOD, B.M. Risk factors for mortality from acute lower respiratory tract infections in young Gambian children. Int. J. Epidemiol., v. 22, p. 1174-82, 1993.

DOCKERY, D.W.; WARE, J.H.; FERRIS, B.G. J.R.; SPEIZER, F.E.; COOK, N.R.; HERMAN, S.M. Change in pulmonary function in children associated with air pollution episodes. J. Air Pollut. Control. Assoc., v. 32, p. 937-42, 1982.

DOCKERY, D.W.; SCHWARTZ, J.; SPENGLER, J.D. Air pollution and daily mortality: Associations with particulates and acid aerosols. Environ. Respir., v. 59, p. 362-73, 1992.

DOCKERY, D.W.; POPE III, C.A.; XU, X.; SPENGLER, J.D.; WARE, J.H.; FAY, M.E.; FERRIS, B.G.; SPEIZER, F.E. An association between air pollution and mortality in six U.S. cities. N. Eng. J. Med., v. 329, p. 17539, 1993. 
DOCKERY, D.W.; POPE III, C.A. Acute respiratory effects of particulate air pollution. Annu. Rev. Public. Health, v.15, p.107-32, 1994.

DOCKERY, D.W., POPE III, C.A. Epidemiology of acute health effects: summary of time-series studies. In: WILSON, R.; SPENGLER, J., ed. Particles in our air. Cambridge, Harvard University Press, 1996. p. 12347.

DUCLOS, P.; SANDERSON, L.M.; LIPSETT, M. The 1987 Forest Fire Disaster in California: assessment of emergency room visits. Arch. Environ. Health, v. 45, p. 53-8, 1990.

ELLEGARD, A. Cooking fuel smoke and respiratory symptoms among women in low-income areas of Maputo. Environ. Health Perspect., v. 104, p. 980-5, 1996.

ELLEGARD, A. Tears while cooking: an indicator of indoor air pollution and related health effects in developing countries. Environ. Res., v. 45, p. 12-22. 1997.

EL KHOURI, MIRAGLIA, S.G. Análise do impacto do consumo de diferentes combustíveis na incidência de mortalidade por doenças respiratórias no Município de São Paulo. São Paulo, 1997. 100p. Dissertação (Mestrado) - Escola Politécnica, Universidade de São Paulo.

ELSON, D. Atmospheric pollution: causes, effects and control policies. Oxford, Basil Blackwell Limited., 1987. p. 157-93.

ELSON, D. Smog alert: managing air quality. London, Earthscan Publications, 1996.

ENCICLOPÉDIA AGRÍCOLA BRASILEIRA. Açúcar. São Paulo, Editora da Universidade de São Paulo, 1995. p. 46-109.

ENCICLOPÉDIA DELTA UNIVERSAL. Açúcar. Rio de Janeiro, Editora Delta, 1980. v. 1, p. 62-6. 
ENCICLOPÉDIA MIRADOR INTERNACIONAL. Açúcar. São Paulo, Encycloppaedia Britannica do Brasil Publicações, 1997. v. 1, p. 93-7

ECHALAR F.; GAUDICHET A. Aerosol emission by tropical forest and savanna biomass burning: characteristic trace elements and fluxes. Geophy. Res. Lett., v. 22 , p. 3039-42, 1995.

FAHRAT, S.C.L. Efeitos da poluição atmosférica na cidade de São Paulo sobre doenças do trato respiratório inferior em uma população pediátrica. São Paulo, 1999, 180p. Tese (Doutorado) - Faculdade de Medicina da Universidade de São Paulo.

FAIRLEY, D. The relationship of daily mortality to suspended particulates in Santa Clara county, 1980-1986. Environ. Health Perspect., v. 89, p.159-68, 1990.

FERLINI, V.L.A. A civilização do açúcar. 11. ed São Paulo, Editora Brasiliense, 1998. p. 10-28.

FERNANDES, A.C. Desempenho da agroindústria da cana-de-açúcar no Brasil (1970/1997). Centro de Tecnologia Copersucar. Comunicação Pessoal. 2000.

FICK, R.B.; PAUL, E.S; MERRIL. W.W; REYNOLDS, H.Y.; LOKE, J.S.O. Alteration in the antibacterial properties of rabbit pulmonary macrophages exposed to wood smoke. Am. Rev. Respir. Dis., v. 129, p. 76-81, 1984.

FIRKET, J. Sur les causes des accidents survenus dans la vallée de la Meuse,lors des brouillards de décembre 1930. Bull. Acad. Roy. Med. Belg., v. 11, p. 683-741, 1931.

FLETCHER R.H.; FLETCHER, S.W.; WAGNER, E.H. Epidemiologia Clínica: elementos essenciais. 3. ed. Artes Médicas, 1996. 
FOLINSBEE, L.J. Human health effects of air pollution. Environ. Health Perspect., v.100, p. 45-56, 1992.

FRANCO, A., Combustão sazonal da cana de açúcar como uma fonte de hidrocarbonetos pouco voláteis. Araraquara. 2001. 97p. Dissertação (Mestrado)- Instituto de Química de Araraquara, Universidade Estadual Paulista.

FRANK, N.R.; YODER, R.E.; BRAIN, J.D.; YOKOYAMA, E. ${ }^{35} \mathrm{SO}_{2}$ absorption by the nose and mouth under conditions of varying concentration and flow. Arch. Environ. Health, v. 18, p. 315-22, 1969.

FRENTE PARLAMENTAR SUCROALCOOLEIRA. O álcool e a nova ordem econômica mundial. São Paulo, Editora Segmento, 1996. p.21-26.

FURRIELA B.R. Proibição da queima na Colheita de Cana-de-Açúcar no Estado de São Paulo. Disponível na Internet: <http:// www.mct.gov.br/clima/comunic_old/queima.htm>. Acesso em: junho 2001.

GEO-2000. GLOBAL ENVIRONMENTAL OUTLOOK. Forest fires and biomass burning, The state of the environmental - global issues. Disponível na internet:<http://www.grid2.cr.usgs.gov/geo2000/english/0040.htm>. Acesso em: setembro 2001a.

GEO-2000. GLOBAL ENVIRONMENTAL OUTLOOK. Regional trends, Asia and the Pacific. Disponível na internet: <http://www.grid2.cr.usgs.gov/geo2000/english/0014.htm>. Acesso em: setembro $2001 b$.

GHARAIBEH, N.S. Effects of indoor air pollution on lung function of primary school children in Jordan. Ann. Trop. Paediatr., v. 16, p. 97-102, 1996. 
GODLESK, J.; SIOUTAS, C.; VERRIER, R.L.; KILLINGSWORTH, C.R.; LOVETT, E.; MURTHY, G.G.K.; HATCH, V.; WOLFSON, J.M.; FERGUSON, S.T.; KOUTRAKIS, P. Inhalation exposure of canines to concentrated ambient air particles. Am. J. Resp. Crit. Care Med., v. 155, p. A246, 1997. Supplement (abstracts).

GRANDE ENCICLOPÉDIA BRASILEIRA DE CONSULTAS E PESQUISA. Cana-de-açúcar. São Paulo, Novo Brasil Editora, 1988. v. 3, p. 731.

GREENBURG, L.; JACOBS, M. B.; DROLETTI, B.M.; FIELD, F.; BRAVERMAN, M.M. Report of an air pollution incident in New York City, 1953. Public Health Reports, v. 77, p. 7-16, 1962 apud ANDERSON, 1999.

GUPTA, B.N.; MATHUR, N.; MAHENDRA, P.; SRIVASTAVA, A.; SWAROOP, V.; AGNIHOTRI, M. A study of the household environmental risk factors pertaining to respiratory disease. Energy Environ. Rev., v. 13, p. 61-7, 1997.

GWYNN, R.C.; BURNETT, R.T.;THURSTON, G.D. A time-series analysis of acidic particulate matter and daily mortality and morbidity in the Buffalo, New York, region. Environ. Health Perspect., v.108, p. 125-33, 2000.

HAJAT, S.; HAINES, A.; GOUBET, S.A.; ATKINSON, R. W.; ANDERSON, H. R. Association of air pollution with daily GP consultations for asthma and lower respiratory conditions in London. Thorax, v. 54, p. 597-605. 1999.

HARRISON, R.; MATERNA, B.L.; ROTHMAN, N. Respiratory health hazards and lung function in wildland firefighters. Occup. Med., v. 10, 0. 850-70, 1995.

HASSELBLAD, V.; KOTCHMAR, D.J.; EDDY, D.M. synthesis of environmental evidence: nitrogen dioxide epidemiology study. J. Air Waste Manage. Assoc., v. 42. p. 57-63, 1992. 
HASTIE, T.J.; TIBSHIRANI, R.J. Generalized additive models. London, Chapman \& Hall. 1990.

HATCH, G.E.; BOYKIN, E.; GRAHAM, J.A.; LEWTAS, J.; POTT,F.; LOUD, K.; MUMFORD, J.S. Inhalable particles and pulmonary host defense: in vitro and in vivo effects of ambient air and combustion particles. Environ. Res., v. 36, p. 67-80, 1985.

HATCH, G.E.; SLADE, R.; HARRIS, L.P.; MACDONNEL, W.F.; DEVLIN, R.B.; KOREN, H.S.; COSTA, D.; MAKEE, J. Ozone dose and effect in human and rats. A comparison using oxygen-18 labeling and bronchoalveolar lavage. Am. Rev. Respir. Crit. Care Med., v. 150, p. 676-683, 1994.

HILL. A. B. The environment and disease: Association or causation? Proc. Roy. Soc. Med., v. 38, p. 295-300. 1965

HOEK, G.; BRUNEKREEF, B. Acute effects of a winter air pollution episode on pulmonary function and respiratory symptoms of children. Arch. Environ. Health, v. 4, p. 328-35, 1993.

HOEK, G.; BRUNEKREEF, B. Effects of low-level winter air pollution concentrations on respiratory health of Dutch children. Environ. Res., v. 64, p. 136-150, 1994.

HOLMAN, C. Sources of air pollution. In: HOLGATE, S. T.; SAMET J. M.; KOREN H. S.; MAYNARD, R. L., ed. Air pollution and health. San Diego, Academic Press, 1999. cap. 8, p. 115-48.

HOUTMEYERS, E.; GOSSELINK, R.; GAYAN-RAMIREZ, G.; DECRAMER, M. Regulation of mucociliary clearance in health and disease. Eur. Respir. J., v. 13, p. 1177-88, 1999.

HUTSON, P.A.; VARLEY, J.G.; SANJAR, S.; KINGS, M.; HOLGATE, S.T.; $\mathrm{CHURCH}, \mathrm{M} . \mathrm{K}$. Evidence that neutrophils do not participate in the late 
phase airways response provoked by ovalbumin inhalation in conscious, sensitized guinea pigs. Am. Rev. Respir. Dis., v. 141, p. 535-9, 1990.

IRVINE, J.E. Sugarcane. In: CHEN, J.C.P.; CHOU, C. Chen-Chou cane sugar handbook: a manual for cane sugar manufactures and their chemists. 12. ed. New York, John Wiley \& Sons, 1993. p. 1-18.

ITO, K.; THURSTON, G.D.; HAYES, C.; LIPPMANN, M. Associations of London, England, daily mortality with particulate matter, sulfur dioxide, and acidic aerosol pollution. Arch. Environ. Health., v. 48, p. 213-20, 1993.

ITO, K.; THURSTON, G.D.; Daily $\mathrm{PM}_{10} /$ mortality associations: an investigation of at-risk subpopulations. J. Exp. Anal. Environ. Epidemiol., v.6, p. 79-95, 1996.

JEDRYCHOWSKI, W. Review of recent studies from central and eastern Europe associating respiratory health effects with high levels of exposure to traditional air pollutants. Environ. Health Perspect., v. 103 , p. 1521, 1995. Supplement 2.

JENKINS, B.M. Atmospheric pollutant emission factors from open burning of sugar cane by wind tunnel simulations. Hawaiian Sugar Planter's Association Aiea, Hawaii, January 1995.

JOHNSON, A.W.; ADERELE, W.I. The association of household pollutants and socio-economic risk factors with the short-term outcome of acute lower respiratory infections in hospitalized pre- school Nigerian children. Ann. Trop. Paediatr., v. 12, p. 421-32, 1992.

KATSOUYANNI, K. Health effects of air pollution in southern Europe: are there interacting factors? Environ. Health Perspect., v. 103(Suppl 2), p. 23-7, 1995. 
KLEINBAUM, D.G.; KUPER, L. L.; MULLER, K. E. Applied regression analysis and other multivariate methods. Belmont, Duxbury Press, 1988.

KINNEY, P.L.; ITO, K.; THURSTON, G.D. A sensitivity analysis of mortality/ $\mathrm{PM}_{10}$ associations in Los Angeles. Inhal. Toxicol., v. 7, p. 59-69, 1995.

KOENING, J.Q.; LARSON, T.V.; HANLEY, Q.S.; REBOLLEDO, V.; DUMLER, K.; CHECKOWAY, H.; WANG, S.Z.; LIN, D.; PIERSON, W.E. Pulmonary function changes in children associated with fine particulate matter. Environ. Res., v. 63, p. 26- 38I, 1993.

KOSSOVE, D. Smoke-filled rooms and lower respiratory disease in infants. South Afr. Med. J., v. 61, p. 622-4, 1982.

KUNII, O. Basic facts-determining downwind exposures and their associated health effects in practice: a case study in the 1997 forest fires in Indonesia. In: HEALTH GUIDELINES FOR VEGETATION FIRE EVENTS, Lima, Peru, 1998, Geneva, WHO, 1999. p. 295-312. (Background papers).

LEMOS, M.; LICHTENFELS, A.J.F.C.; AMARO Jr, E.; MACCHIONE, M.; MARTINS, M.A.; KING, M.; BÖHM, G.M; SALDIVA, P.H.N. Quantitative patology of nasal passages in rats exposed to urban levels of air pollution. Environ. Res., v. 66, p. 87-95, 1994.

LIMA, A.L.; LIGO, M.A.V.; CABRAL, O.M.R.; BOEIRA, R.C.; PESSOA, M.C.P.Y.; NEVES, M.C. Emissão de gases do efeito estufa proveniente da queima de resíduos agrícolas no Brasil. Jaguariúna, Embrapa Meio Ambiente, 1999.

LIN, C.A. Efeitos da poluição atmosférica sobre a morbidade respiratória aguda na população infantil de São Paulo. São Paulo, 1997. 115p. Tese (Doutorado) - Faculdade de Medicina, Universidade de São Paulo. 
LIN, C.A; MARTINS, M.A.; FARHAT, S.L.; POPE III, C.A.; CONCEIÇÃO, G.M.S.; ANASTÁCIO, M.V.; HATANAKA, M.; ANDRADE, W.C; HAMAUE, W.R.; BÖHM, G.M.; SALDIVA, P.H.N. Air pollution and respiratory illness of children in São Paulo, Brazil. Paediatr. Perinat. Epidemiol., v.13, p.475-87, 1999.

LINN, W.S.; SZLACHCIC, Y.; GONG, H. JR.; KINNEY, P.L.; BERHANE, K.T. Air pollution and daily hospital admissions in metropolitan Los Angeles. Environ. Health Perspect., v.108, p.427-34, 2000.

LIPFERT, F.W.; HAMMERSTROM, T. Temporal patterns in air pollution and hospital admissions. Environ. Res., v. 59, p. 374-99, 1992.

LIPFERT, F.W. Air pollution and community health: a critical review and data sourcebook. New York. Van. Nostrand Reinhold, 1994.

LIPFERT, F.W.; WYZGA, R.E. Air pollution and mortality: issues and uncertainties. J. Air Waste Manag. Assoc., v. 45, p. 949-66, 1995.

LIPSETT, M.; HURLEY, S.; OSTRO, B. Air pollution and emergency room visits for asthma in Santa Clara Country, California. Environ. Health Perspect., v.105, p. 216-22, 1997.

LIU, D.; TAGER, IRA, B.; BALMES, J.R.; HARRISON, R.J. The effect of smoke inhalation on lung function and airway responsiveness in wildland fire fighters. Am. Rev. Respir. Dis., v. 146, p. 1469-73, 1992.

LOBERT, J.M. Importance of biomass burning in the atmospheric budgets of nitrogen-containing gases. Nature, v. 346, p. 552-4, 1990.

LOBERT, J.M.; SCHARFFE, D.H.; HAO, W.M.; KUHLBUSH, T.A.; SEUWEN, R.; WARNECK, P.; CRUTZEN, P.J. Experimental evaluation of biomass burning emissions: nitrogen and carbon containing compounds. In: LEVINE, J.S., ed. Global biomass burning, Cambridge, The MIT Press, 1991. cap. 36, p.289-304. 
LOBERT, J.M.; and WARNATZ, J. Emissions from combustion process in vegetation. In; CRUTZEN, P.J.; GOLDAMMER J.G., ed. Fire in the environment. Chichester, John Wisley \& Sons, 1993. cap 2, p. 15-38.

LOFTI, C.E.P.; BRENTANI. M.M.; BÖHN, G.M.; Assesment of the mutagenic potential of ethanol auto engine exhaust gases by the salmonella typhimurium microsomal mutagenesis assay, using a direct exposure method. Environ. Res., v. 52, p. 225-30. 1990.

LOGAN, W.P.D. Mortality in London fog incident, 1952. Lancet, v. 1, p. 336-8,1953.

LONG, W.; TATE, R.B.; NEUMAN, M.; MANFREDA, J.; BECKER, A.B.; ANTHONISEN, N.R. Respiratory symptoms in a susceptible population due to burning of agricultural residue. Chest, v.113, p.351-7, 1998.

LOPEZ-BRAVO, I.M.; SEPULVEDA, H.; VALDES, I. Acute respiratory illness in the first 18 months of life. Pan. Am. J. Public Health, v.1, p. 9-17, 1997.

MAGALHÃES J.P.A.; KUPERMAN, N.; MACHADO, R.C. Proálcool, uma avaliação global. Rio de Janeiro, Astel, Assessores Técnicos, 1991. p. 13-39

MALALAY J. A review of factors affecting the human health impacts of air pollutants from forests fires. In: HEALTH GUIDELINES FOR VEGETATION FIRES EVENTS, Lima, Peru, 1998. Geneva, WHO, 1999. p. 255-70. (Background papers).

MALIK, S.K. Exposure to domestic cooking fuels and chronic bronchitis. Indian J. Chest Dis. Allied Sci., v. 27, p. 171-4, 1985.

MARINHO, E.V.A.; KIRCHHOFF V.W.H. Projeto fogo: um experimento para avaliar efeitos das queimadas de cana-de-açúcar na baixa temperatura. Revista Bras. Geofísica. v. 9, p 107-19, 1991. 
MASSAD, E.; SALDIVA, C.D. ; CARDOSO, L.M.N. ; SILVA, R.; SALDIVA, P.H.N. ; BÖHM, G.M. Acute toxicity of gasoline and ethanol automobile engine exhaust gases: comparative toxicity of engine fuel, ethanol exhaust fumes.; Toxicol. Lett., v. 26, p. 187-93, 1985.

MASSAD, E.; SALDIVA, P.H.N.; SALDIVA, C.D. ; CALDEIRA, M.P.R.; CARDOSO, L.M.N.; MORAIS, A.M.S.; CALHEIROS, D.F.; SILVA, R.; BÖHM, G.M. Toxicity of Prolonged Exposure to Ethanol and Gasoline Auto Engine Exhaust Gases.; Environ. Res., v. 40, p. 479-86, 1986.

MASSAD, E.; BÖHN, G.M.; SALDIVA, P.H.N. Ethanol fuel toxicity. In: CORN, M., Handbook of hazardous materials. New York, Academic Press, 1993. p. 265-75.

MASTER, K.M. Air pollution in New Guinea. Cause of chronic pulmonary disease among stone-age natives in the highlands. JAMA, v. 228, p. 1653, 1974.

MEDINA, S.; LE TERTRE, A.; QUÉNEL, P.; LE MUOLLEC, Y.; LAMELOISE, P.; GUZZO, J.C.; FESTY, B.; FERRY, R.; DAB, W. Air pollution and doctors'house calls: results from the ERPURS system for monitoring the effects of air pollution on public health in greater Paris, France, 19911995. Environ. Res., v. 75, p. 73-84. 1997.

MELO, F.H.; FONSECA, E G. Proálcool, energia e transportes. São Paulo, Livraria Pioneira Editora, 1981. p 1-3.

MICHELOZZI, P.; FORASTIERE, F.; FUSCO, D.; PERUCCI, C.A.; OSTRO, B.; ANCONA, C.; PALLOTTI, G. Air pollution and daily mortality in Rome, Italy. Occup. Environ. Med., v. 55, p. 605-610, 1998.

MINISTÉRIO DA AGRICULTURA, PECUÁRIA E ABASTECIMENTO. Principais produtos de lavouras temporárias. Disponível na internet: <http://agricultura.gov.br>. Acesso em: maio 2001. 
MISHRA, V.K.; RETHEFORD, R.D.; SMITH, K.R. Biomass cooking fuels and prevalence of tuberculosis in India. Int. J. Infect. Dis., v. 3, p. 119-29, 1999 a.

MISHRA, V.K.; RETHEFORD, R.D.; SMITH, K.R. Biomass cooking fuels and prevalence of blindness in India. J. Environ. Med., v.1, p. 189-99, 1999 b

MOHAN, M.; SPERDUTO, R.D.; ANGRA, S.K. Indian-US case control study of age-related cataracts. Arch. Ophthalmol., v. 107, p. 670-6, 1989.

MOHAMMED, N.; NG'ANG'A, L.; ODHIAMBO, J.; NYAMWAYA, J.; MENZIES, R. Home environment and asthma in Kenyan school children: a case-control study. Thorax, v. 50, p. 74-8, 1995.

MOOLGAVKAR, S.H.; LUEBECK, E.G.; HALL, T.A.; ANDERSON, E.L. Particulate air pollution, sulfur-dioxide, and daily mortality: A reanalysis of the Steubenville data. Inhal. Toxicol., v. 7, p. 35-44, 1995.

MOOLGAVKAR, S.H.; LUEBECK, E.G. A critical review of the evidence on particulate air pollution and mortality. Epidemiology, v. 7, p. 420-8, 1996.

MOOLGAVKAR, S.H.; LUEBEK, E.G.; ANDERSON, E.L. Air pollution and hospital admissions for respiratory causes in Minneapolis- St. Paul and Birmingham. Epidemiology, v.8, p.364-77, 1997.

MORAWSKA, L.; THOMAS, S.; BONFINGER, N.D.; WAINWRIGHT, D.; NEALE, D. Comprehensive characterization of aerosols in a subtropical urban atmosphere: particle size distribution and correlation with gaseous pollutants. Atmospheric Environmental, v. 32, p. 2461-78, 1998.

MORAWSKA, L.; THOMAS, S. Particle size characteristics from vegetation burning. In: Health Guidelines for Vegetation fires. WHO, 1999.

MORGENSTERN, H. Uses of ecological analysis in epidemiologic research. Am. J. Public Health, v.72, p.1336-44, 1982. 
MORGENSTERN, H. Ecologic studies in epidemiology: concepts, principles, and methods. Annu. Rev. Public Health, v.16, p.61-81, 1995.

MORRIS, K.; MORGENLANDER, M. COULEHAN, J.L.; GAHAGEN, S.; ARENA, V.C., MORGANLANDER M. Wood-burning stoves and lower respiratory tract infection in American Indian children. Am. J. Dis. Child., v. 144, p. 105-8, 1990.

MUKERJEE D. Health impact of polychlorinated dibenzo-p-dioxins: a critical review. J. Air Waste Manage. Assoc. , v. 48, p. 157-65, 1997.

MULLEN, J.B.; WRIGHT, J.L.; WIGGS, B.R.; PARE, P.D.; HOGG, J.C. Reassessment of inflammation of airways in chronic bronchitis. Br. Med. J., v. 291, p. 1235-9, 1985.

MTANGO, F.D.; NEUVIANS, D.; BROOME, C.V.; HIGHTOWWER, A.W., $\mathrm{PIO}, \mathrm{A}$. Risk factors for deaths in children under 5 years old in Bagamoyo district, Tanzania. Trop. Med. Parasitol., v. 43, p. 229-33, 1992.

NABAIS, R.M.M.A.C. Alguns aspectos relativos à queima de canaviais. Piracicaba, CETESB, 1981.

NAUENBERG, E.; BASU, K.; Effects of insurance coverage on the relationship between asthma hospitalizations and exposure to air pollution. Public Health Rep., v. 114, p. 135-48, 1999.

NOORHASSIM, I.; RAMPAL, K.G.; HASHIM, J.H. The relationship between prevalence of asthma and environmental factors in rural households. Med. J. Malaysa, v. 50, p. 263-7, 1995.

NORBOO, T.; YAHYA, N.B.; HEADY, J.A.; BALL, K.P. Domestic pollution and respiratory illness in a Himalayan village. Int. J. Epidemiol., v. 20, p. $749-57,1991$. 
NORRIS, G.; YOUNG-PONG, S.N.; KOENIG, J.Q.; LARSON, T.V.; SHEPPARD, L.; STOUT, J.W. An association between fine particles and asthma emergency department visits for children in Seattle. Environ. Health Perspect, v.107, p.489-93. 1999.

NORRIS, G.; LARSON, T.; KOENIG, J.; CLAIBORN, C.; SHEPPARD, L.; FINN, D. Asthma aggravation, combustion, and stagnant air. Thorax, v.55, p. $466-70.2000$.

NOVA ENCICLOPÉDIA BARSA. Açúcar. São Paulo, Encyclopedia Britannica do Brasil Publicações, Companhia Melhoramentos de São Paulo, 1997. v.1, p. 62-8.

NOVA ENCICLOPÉDIA BARSA. Cana-de-açúcar. São Paulo, Macropédia Britânica do Brasil, 2000. v. 3, p. 381-2.

OMETTO, J.G.S. O álcool combustível e o desenvolvimento sustentado. São Paulo, PIC Editorial, 1998. p. 55-7.

OSTRO, B.D.The effects of air pollution on work loss and morbidity. J. Environ. Econ. Manag., v. 10, p. 371-82, 1983.

OSTRO,B.D. Air pollution and morbidity revisited: A specification test. J. Environ. Econ. Manag.,v. 14, p. 87-98, 1987.

OSTRO, B.D.; ROTHSCHILD, S. Air pollution and acute respiratory morbidity: An observation study of multiple pollutants. Environ. Res., v. 50, p. 238-247, 1989.

OSTRO, B.D. Association between morbidity and alternative measures of particulate matter. Risk Anal., v. 10, p. 421-7, 1990.

OSTRO, B.D.; LIPSETT, M.J.; WIENER, M.B.; SELNER, J.C. Asthmatic response to airbone acid aerosols. Am. J. Public Health, v. 1, p. 694$702,1991$. 
OSTRO, B. The association of the air pollution and mortality: examining the case for inference. Arch. Environ. Health., v. 48, p. 336-42, 1993.

OSTRO, B.; SANCHEZ, J.M.; ARANDA, C.; ESKELAND, G.S. Air pollution and mortality: Results from a study of Santiago, Chile. J. Exp. Anal. Environ. Epidemiol., v. 6, p. 97-114,1996.

OSTRO, B.; CHESNUT, L. Assessing the health benefits of reducing particulate matter air pollution in the United States. Environ. Res., v. 74, p. 94-106, 1998.

PADMAVATI, S.; PATHAK, S.N. Chronic cor pulmonale in Delhi. Circulation, v.20, p. 343-52, 1959.

PAMPLONA C. Proálcool, impactos em termos técnico-econômicos e sociais do programa no Brasil. Belo Horizonte, Ministério da Indústria e Comércio Instituto do Açúcar e do Álcool, 1984. p. 7-15.

PANDEY, M.R. Prevalence of chronic bronchitis in a rural community of the Hill Region of Nepal. Thorax, v. 39, p. 331-36, 1984a.

PANDEY, M.R. Domestic smoke pollution and chronic bronchitis in a rural community of the Hill Region of Nepal. Thorax, v. 39, p. 337-339, 1984b.

PANDEY, M.R.; BOLEIJ, J.S.; SMITH, K.R; WAFULA. E.M. Indoor air pollution in developing countries and acute respiratory infection in children. Lancet, v. 1, p. 427-9, 1989.

PAUWELS, R.; KIPS, J.; PELEMAN, R.; STRAETEN, M.V.D. The effects of endotoxin inhalation on airway responsiveness and cellular influx in rats. Am. Rev. Respir. Dis., v. 141, p. 540-5, 1990.

PEREIRA, L.A.A. Associação entre poluição atmosférica e perdas fetais tardias no município de São Paulo. São Paulo, 1999. 155 p. Tese de Doutorado - Faculdade de Medicina, Universidade de São Paulo. 
PEREIRA, L.F.F., Avaliação e tratamento da asma aguda no adulto. In; PEREIRA, C.A.C.; CARVALHO, C.R.R.; NAKATANI, J., ed. Pneumologia atualização e reciclagem. São Paulo, Atheneu, 1996. cap 10, p.206-23.

PEREIRA, P.M.; SALDIVA, P.H.N.; SAKAE, R.S.; BÖHM, G.M.; MARTINS, M.A. Urban levels of air pollution increase lung responsiveness in rats. Environ. Res,, v.69, p.96-101, 1995.

PEREZ-PADILLA, R.; REgALADO, J.; VEDAL, S. CHAPELA, R.; SAMSPRE. R.; SELMAN, M. Exposure to biomass smoke and chronic airway disease in Mexican women. A case control study. Am. J. Respir. Crit. Care Med., v. 154, p. 701-6, 1996.

PEREZ-PADILLA, R.; PEREZ-GUZMAN, C.; BAEZ-SALDANA, R.; TORRESCRUZ, A. Cooking with biomass stoves and tuberculosis: a case control study. Int. J. Tuberc. Lung Dis., v. 5, p. 441-7, 2001.

PHONBOON, K.; PAISARN-UCHAPONG, O.; KANATHARANA, P.; AGSORN, S. Smoke episodes emissions characterization and assessment of health risks related downwind air quality-case study, Thailand. In: HEALTH GUIDELINES FOR VEGETATION FIRE EVENTS, Lima, Peru, 6-9. 1998. Geneva, WHO, 1999. p. 334-58. (Background papers).

PISTELLY, R. Wood smoke and asthma: a controversial issue. Am. J. Respir. Crit. Care Med., v. 155, p. A941, 1997.

PONKA, A. Asthma and low-level air pollution in Helsinki. Arch. Environ. Health, v. 46, p. 262-70, 1991.

POPE III, C.A. Respiratory diseases associated with community air pollution and a steel mill, Utah Valley. Am. J. Public Health, v.79, p.623-8, 1989. 
POPE III, C.A. Respiratory hospital admissions associated with $\mathrm{PM}_{10}$ pollution in Utah, Salt Lake, and Cache Valleys. Arch. Environ. Health, v. 46, p. 90-7, 1991.

POPE III, C.A.; DOCKERY, D.W.; SPENGLER, J.D.; RAIZENNE, M.E. Respiratory health and $\mathrm{PM}_{10}$ pollution: a daily time series analysis. Am. Rev. Respir. Dis., v. 144, p. 668-74, 1991.

POPE III, C.A.; DOCKERY, D.W. Acute health effects of $\mathrm{PM}_{10}$ pollution on symptomatic and asymptomatic children. Am. Rev. Respir. Dis., v. 145, p. 1123-8, 1992.

POPE III, C.A.; SCHWARTZ, J.; RANSOM, M.R. Daily mortality and $\mathrm{PM}_{10}$ pollution in Utah Valley. Arch. Environ. Health, v. 47, p. 211-7, 1992.

POPE III, C.A.; KANNER, R.E. Acute effects of $\mathrm{PM}_{10}$ pollution on pulmonary function of smokers with mild to moderate chronic obstructive pulmonary disease. Am. Rev. Respir. Dis., 147, p. 1336-40, 1993.

POPE III, C.A.; THUN, M.J.; MAMBOODIRI, M.M.; DOCKERY, D.W.; EVANS, J.S.; SPEIZER, F.E.; HEATH, C.W. Particulate air pollution as a predictor of mortality in a prospective study of U.S. adults. Am. J. Respir. Crit. Care Med. Vol. 151, p. 669-74, 1995a.

POPE III, C.A.; BATES, D.V.; RAIZENNE, M.E. Health effects of particulate air pollution: time for reassessment? Environ Health Perspect., v. 103, p. $472-80,1995 b$.

POPE III, C.A.; DOCKERY, D.W.; SCHWARTZ, J. Review of epidemiologic evidence of health effects of particulate air pollution. Inhal. Toxicol.,v. 7 , p. $1-18,1995 \mathrm{c}$.

POPE III, C.A.; SCHWARTZ, J. Time series for the analysis of pulmonary health data. Am. J. Respir. Crit. Care Med., v. 154, p. S229-33, 1996. 
POPE III, C.A.; DOCKERY, D.W. Epidemiology of chronic health effects: cross-sectional studies. In: WILSON, R.; SPENGLER, J., ed. Particles in our air. Cambridge, MA, Harvard University Press, 1996. p. 149-167.

POPE III, C.A.; DOCKERY, D.W. Epidemiology of particles effects. In: HOLGATE, S.T.; SAMET, J.M.; KOREN, H.S.; MAYNARD, R.L., ed. Air pollution and health. San Diego, Academic Press, 1999. cap. 31, p. 673-705.

PRADO JUNIOR, C. Historia econômica do Brasil. 43. ed São Paulo, Editora Brasiliense, 1998. p. 243-8.

PREFEITURA MUNICIPAL DE ARARAQUARA, Secretária de desenvolvimento econômico. Infra-estrutura Básica. Araraquara, 2000.

PRYOR, W.A.; LIGHTSEY, J.W. Mechanism of nitrogen dioxide reactions: initiation of lipid peroxidation and the production of nitrous acid. Science, v. 214, p. $435-7,1981$.

QURESHI, K. Domestic smoke pollution and prevalence of chronic bronchitis/asthma in a rural area of Kashmir. Indian J. Chest Dis. Allied Sci., v. 36, p. 61-72, 1994.

RADKE, L.F.; LYONS, J.H.; HOBBS, .PV.; HEGG, D.A.; SANDBERG, D.V. Airborne monitoring and smoke characterization of prescribed fires on forest lands in western Washington and Oregon-final report .Forest Service, Portland, OR. Pacific Northwest Research Station. Government Reports Announcements Index, Issue., v. 16, FSGTR PNW p. 251, 1990 apud WHO, 1999.

RAHLENBECK, S.I.; KAHL, H. Air population and mortality in East Berlin during the winters of 1981 to 1989. Int. J Epidemiol., v. 25, p. 1220-6, 1996.

RANSOM, M.R.; POPE III, C.A. Elementary school absences and $\mathrm{PM}_{10}$ pollution in Utah Valley. Environ. Res., v. 58, p. 204-19, 1992. 
REINHARDT, T.; OTTMAR, R. Smoke exposure among wildland firefighters: A review and discussion of current literature, United States Department of Agriculture, Forest Service. Pacific Northwest Res. Station, 1997.

RIPOLI, T.C.C.; RIPOLI, M.L.C. Efectts of the pre-harvest burn in sugar cane (Saccharum spp), in Brazil. Rev. di Ingegneria Agrária. v.4, p. 2-7, 2001.

ROEMER, W.; HOEK, G.; BRUNEKREEF, B. Effect of ambient winter in air pollution on respiratory health of children with chronic respiratory symptoms. Am. Rev. Respir. Dis., v. 147, p. 118-24, 1993.

ROTHMAN, N.; FORD, D.P.; BASER, M.E.; HANSEN, J.Á.; O'TOOLE, T.; TOCKMAN, M.S.; STRICKLAND, P.T. Pulmonary function and respiratory symptoms in firefighters. J. Occup. Med., v. 33, p. 1163-7, 1991.

SALDIVA, P.H.N,; MASSAD, E.; CALDEIRA, M.P.R; CALHEIROS, D.F. ; SALDIVA, C.D.; NICOLELIS, M.A.L.; BÖHM, G.M. Pulmonary function of rats exposed to ethanol and gasoline fumes. Braz. J. Med. Biol. Res. , v. 18, p. 573-7, 1985.

SALDIVA, P.H.N.; KING, M.; DELMONTE, V.L.C.; MACCHIONE, M.; PARADA, M.A.C.; DALIBERTO, M.L.; SAKAI, R.S.; CRIADO, P.M.P.; SILVEIRA, P.L.P.; ZIN, W.A.; BÖHM, G.M. Respiratory alterations due to urban air pollution: an experimental study in rats. Environ. Res., v. 57, p. 19-33, 1992.

SALDIVA, P.H.N.; LICHTENFELS, A.J.F.C.; PAIVA, P.S.O.; BARONE, I.A.; MARTINS, M.A.; MASSAD, E.; PEREIRA, J.C.R.; XAVIER, V.P.; SINGER, J.M.; BÖHM, G.M. Association between air pollution and mortality due to respiratory diseases in children in Sao Paulo, Brazil: a preliminary report. Environ. Res., v. 65, p. 218-25, 1994. 
SALDIVA, P.H.N.; POPE III, C.A.; SCHWARTZ, J.; DOCKERY, D.W.; LICHTENFELS, A.J.; SALGE, J.M.; BARONE, I.; BÖHM, G.M. Air pollution and mortality in elderly people: a time-series study in Sao Paulo, Brazil. Arch. Environ. Health., v. 50, p. 159-63, 1995.

SALDIVA, P.H.N. Poluição atmosférica e saúde: uma abordagem experimental. GREEPEACE, SOS, chega de poluição. Brasil, 1998.

SAMET, J.M.; SPEIZER, F.E.; BISHOP, Y.; SPENGLER, J.D.; FERRIS, B.G. JR. The relationship between air pollution and emergency room visits in an industrial community. J. Air Pollut. Control. Assoc., v. 31, p. 236240, 1981.

SAMET, J.M.; LAMBERT, W.E.; SKIPPER, B.J.; CUSHING, A.H.; MCLAREN, L.C.; SCHWAB, M.; SPENGLER, J.D. A study of respiratory illnesses in infants and nitrogen dioxide exposure. Arch. Environ. Health., v.40, p. 57-63, 1992.

SAMET, J.M.; ZEGER, S.L.; BERHANE, K. The association of mortality and particulate air pollution. In: Particulate Air Pollution and Daily Mortality, Replication and Validation of Selected Studies, The Phase I Report of the Particle Epidemiology Evaluation Project. Cambridge, Health Effects Inst.,1995.

SAMET, J.M; MARK, J.U. Indoor and outdoor air pollution. In: FISHMAN A., ed. Fishsman pulmonary disease and disorder, 3.ed. New York, McGraw-Hill, 1998.

SCHMITZBERGER, R.; RHOMBERG, K.; BUCHELE, H.; PUCHEGGER, R.; SCHIMITZBERGER-ER-NATZMER, D.; KEMMLER, G.; PANOSCH, B. Effects of air pollution on the respiratory tract of children. Pediat. Pulmonol., v. 15, p. 68-74, 1993.

SCHWARTZ, J. Particulate air pollution and daily mortality in Detroit. Environ. Res., v. 56, p. 204-13, 1991a. 
SCHWARTZ, J. Particulate air pollution and daily mortality: a synthesis. Public Health Rev., v. 19, p. 39-60, 1991 b.

SCHWARTZ, J.; DOCKERY, D.W. Increased mortality in Philadelphia associated with daily air pollution concentration. Am. Rev. Respir. Dis., v. 45, p. $600-4,1992 a$.

SCHWARTZ, J.; DOCKERY, D.W. Particulate air pollution and daily mortality in Steubenville, Ohio. Am. J. Epidemiol., v.135, p.12-9, 1992b.

SCHWARTZ J. Air pollution and daily mortality in Birmingham, Alabama. Am. J. Epidemiol. v. 137, p. 1136-47, 1993.

SCHWARTZ, J; KOENIG, J. SLATER, D.; LARSON, T. Particulate air pollution and hospital emergency visits for asthma in Seattle. Am. Rev. Respir. Dis., v. 147, p. 826-31, 1993.

SCHWARTZ, J. Air pollution and daily mortality: A review and meta analysis. Environ. Res., v. 64, p. 36-52, 1994 a.

SCHWARTZ, J. Total suspended particulate matter and daily mortality in Cincinnati, Ohio. Environ. Health Perspect., v. 102, p .186-9, 1994b.

SCHWARTZ, J. Air pollution and hospital admissions for the elderly in Detroit. Am. J. Respir. Crit Care Med., v. 150, p. 648-55, 1994c.

SCHWARTZ, J. Air pollution and hospital admissions for the elderly in Birmingham, Alabama. Am. J. Epidemiol., v. 139, p. 589-90, 1994d.

SCHWARTZ, J. Nonparametric smoothing in the analysis of air pollution and respiratory illness. Can. J. Stat., v.22, p. 471-478, 1994e.

SCHWARTZ, J. Short term fluctuations in air pollution and hospital admissions of the elderly for respiratory disease. Thorax, v.50, p.531-8, 1995. 
SCHWARTZ, J.; DOCKERY, D.W.; NEAS, L.M. Is daily mortality associated specifically with fine particles? J. Air Waste Manage. Assoc., v. 46, p. 927-39, 1996.

SERRA, A.; MOCCI, F.; RANDACCIO, F.S. Pulmonary function in Sardinian fire fighters. Am. J. Ind. Med., v. 30, p. 78-82, 1996.

SHARKEY B., ed. Health hazards of smoke: recommendation of the April 1997 Consensus Conference. Technical Report 9751-2836-MTDC. Missoula, MT: United States Departament of Agriculture, Forest Service, Missoula Technology and Development Center, 1997. p.84.

SHEPPARD, L.; LEVY, D.; NORRIS, G.; LARSON, T.V.; KOENIG, J.Q. Effects of ambient air pollution on nonelderly asthma hospital admissions in Seattle, Washington, 1987-1994. Epidemiology, v. 10, p. 23-30, 1999.

SHI, M.M.; GODLESI, J.J.; PAULAUSKIS, J.D. Regulation of macrophage inflammatory protein-1 mRNA by oxidative stress. J. Biol. Chem., v. 271, p. 5878-5883, 1996 a.

SHI, M.M.; GODLESKI, J.J.; PAULAUSKIS, J.D. Elevation of KC (cytokineinduced neutrophil chemoattractant) mRNA in alveolar macrophages by quinone-induced oxidative stress. Am. J. Respir. Crit. Care Med., v. 153, p. A30, 1996 b.

SHIKIDA, P.F.A. A evolução diferenciada da agroindústria canavieira no Brasil, de 1975 a 1995. Cascavel, Edunioeste, 1998, p. 33-62.

SHRENK, H.H.; HEIMANN, H.; CLAYTON, G.D.; GAFAFER, W.M.; WEXLER, H. Air Pollution in Donora, PA: epidemiology of the unusual smog episode of October 1948: preliminary report. Public Health Bulletin, n. 306. Whashington, US Public Health Service, 1949.

SHY, C.M.; Epidemiologic evidence and the United States air quality standards. Am. J. Epidemiol., v. 110, p. 661-71, 1979. 
SIMONSEN, R.C. História econômica do Brasil. 7. ed São Paulo, Companhia Editora Nacional, 1977, p. 95-123.

SMITH, K.R.; SAMET, J.M.; ROMIEU, I.; BRUCE, N. Indoor air pollution in developing countries and acute lower respiratory infections in children. Thorax, v. 55, p. 518-32, 2000.

SOCIEDADE BRASILEIRA DE PNEUMOLOGIA E TISIOLOGIA. II Consenso brasileiro no manejo da asma. J. Pneumol., v. 24, n.4.

SPIX, C.; WICHMANN, H.E. Daily mortality and air pollutants: Findings from Köln, Germany. J. Epidemiol. Commun. Health. v. 50, p. S52-S58, 1996. Supplement 1.

STYER, P.; MCMILLAN, N.; GAO, F.; DAVIS, J.; SACKS, J. The effects of airbone particulate matter on daily death counts. Environ. Health Perspect., v. 103, p. 490-7, 1995.

SUNYER, J.; ANTÓ, J.M.; MURILLO, C.; SAEZ, M. Effects of urban air pollution on emergency room admissions for chronic obstructive pulmonary disease. Am. J. Epidemiol., v. 134, p. 277-86, 1991.

SUNYER, J.; SAEZ, M.; MURILLO, C.; CASTELLSAGUE, J.; MARTINEZ, F.; ANTO, J.M. Air pollution and emergency room admission for chronic obstructive pulmonary disease: A 5-years study. Am. J. Epidemiol., v. 137, p. 701-5, 1993.

SUNYER, J.; CASTELlSAGUE, J.; SAEZ, M.; TOBIAS, A.; ANTO, J.M. Air pollution and mortality in Barcelona. J Epidemiol. Commun. Health. v. 50, p. S76-S80, 1996. Supplement 1

S-PLUS FOR WINDOWS tm, VERSION 4.0. Data Analysis Products Division, MathSoft, Inc. Seattle, Washington. 1997.

SPSS FOR WINDOWS, RELEASE 6.0. SPSS Inc Chicago, IL. 1993. 
TAN, C.W.; QIU, D.; LIAM, B.L; N.G.; T.P.; LEE, S.L.; VAN EEDEN, S.F.; D'YACHKOVA, Y.; HOGG, J.C. The human bone marrow response to acute air pollution caused by forest fires. Am. J. Respir. Crit. Care Med., v. 161, p.1213-7, 2000.

TOLEDO, V.V; GANCHO, C.V. Verdes canaviais. 2. ed São Paulo, Editora Moderna, 1996. p. 13-6; 42-58.

TOULOUMI, G.; SAMOLI, E.; KATSOUYANNI, K. Daily mortality and "winter type" air pollution in Athens, Greece: A time-series analysis within the APHEA project. J. Epidemiol. Community Health. (Supp 1)., v. 50, p. S47-S51, 1996.

THOMPSON, A.; DAUGHTON, D.; ROBBINS, R.; GHAFOURI, M.; OEHLERKING, M.; RENNARD. S. Intraluminal airway inflammation in chronic bronchitis. Am. Rev. Respir. Dis., v. 140, p. 1527-37, 1989.

THURSTON, G.D.; ITO, K.; KINNEY, P.L.; LIPPMANN, M. A multi-year study of air pollution and respiratory hospital admissions in there New York state metropolitan areas: Results for 1988 and 1989 summers. J. Exp. Anal. Environ. Epidemiol. v. 2, p. 429-50, 1992.

THURSTON, G.D. A critical review of PM10-mortality time-series studies. J. Exp. Anal. Environ. Epidemiol.,v. 6, p. 3-21, 1996.

TOLBERT, P.E.; MULHOLLAND, J.A.; MACLNTOSH, D.L.; XU,F.; DANIELS, D.; DEVINE, O.J.; CARLIN, B.P.; KLEIN, M.; DORLEY, J.; BUTLER, A.J.; NORDENBERG, D.F.; FRUMKIN, H.; RYAN, P.B.; WHITE, M.C. Air quality and pediatric emergency room visits for asthma in Atlanta, Georgia. Am. J. Epidemiol., v.151, p. 798-810. 2000.

ÚNICA-UNIÃO DA AGROINDUSTRIA CANAVIEIRA DO ESTADO DE SÃO PAULO. Retrato da safra 00/01. Informativo Única. v. 40, 2001. 
USDA-UNITED STATES DEPARTAMENT AGRICULTURE. Brazilian sugar cane production. Disponível na Internet: <http://www.usda.gov.> Acesso em: setembro 2001.

U.S. ENVIRONMENTAL PROTECTION AGENCY. Emission factor documentation for AP-42, section 2,5, open burning. Office of Air Quality Planning and Standards Office of Air and Radiation, USEPA, Research Triangle Park, North Carolina 27711, September 1992.

U.S. ENVIRONMENTAL PROTECTION AGENCY. Measuring Air Quality: The Pollutant Standards Index. Office of Air Quality Planning and Standards, Research Triangle Park, NC, EPA 451/K-94-001, 1994.

U.S. ENVIRONMENTAL PROCTECTION AGENCY. National Air Quality and Emissions Trends Report, 1995. Office of Air Quality Planning and Standards, Research Triangle Park, NC, 1996a.

U.S. ENVIRONMENTAL PROCTECTION AGENCY. Air quality criteria for particulate matter, v. 2. EPA/600/P-95/0016F. 1996b

U.S. ENVIRONMENTRAL PROTECTION AGENCY. Particulate matter research needs for human health risk assessment to support future reviews of the National Ambient Air Quality Standars for particulate matter, US Environmental Protection Agency, National Center for Environmental Assessment, Research Triangle Park, NC 27711, EPA/600/R-97/132F, 1998a.

U.S. ENVIRONMETAL PROTECTION AGENCY. Carcinogen assessment group evaluation an estimation of potential carcinogenic risks of polynucleum aromatic hydrocarbons, Cincinatti, 1998b.

UTELL, M.J.; SAMET, J.M.; BATES, D.V.; BECKLAKE, M.R.; DOCKERY, D.W; LEADERER, B.P; MAUDERLY, J.L.; SPEIZER, F.E. Air pollution and health. Report on a Symposium. Am. Rev. Respir. Dis., v.10, p.1065-8, 1988. 
VEDAL, S. Ambient particles and health: lines that divide. J. Air Waste Manag. Assoc., v. 47, p. 551-81, 1997.

VERHOEFF, AP.; HOEK, G.; SCHAWARTZ, J.; VAN, WIJNEM, J.H. Air pollution and daily mortality in Amsterdam. Epidemiology, v. 7, p. 225230, 1996.

VICTORA, C.G.; FUCHS, S.C.; FLORES, J.A.; FONSENCA, W.; KIRKWWOOD, B. Risk factors for pneumonia among children in a Brazilian metropolitan area. Pediatrics, v. 93, p. 977-85, 1994.

WALTERS, D.M.; BREYSSE, B.G.Jr.; WILLS-KARP, M.; Comparison of effects of various sources of particulate matter on pulmonary inflammation. Am. J. Respir. Crit. Care Med., v. 159 , p.A 25, 1999.

WARD, D.E.; CORE, J.E. Source emission profiles for Douglas-fir and hemlock slash burning. In: Proceedings of the Pacific Northwest International Section Meeting of the Air Pollution Control Association, Portland, OR, November 1984, Pittsburgh, PA. 1984 apud WHO, 1999.

WARD, D.E.; HARDY, C. Organic and elemental profiles for smoke from prescribed fires. In: WATSON, J. G. ed. Receptor models in air resources management: Transactions of an international speciality conference of the Air and Waste Management Association; San Francisco, Pittsburg, 1989. p. 229-321 apud WHO, 1999.

WARD, D.E.; HARDY, C.C. Smoke emissions from wildland fires. Environ. Int., v.17, p117-34, 1991.

WARD, D.E.; SUSSOT, R.A.; KAUFFMAN, J.B. Smoke and fire characteristics for cerrado and deforestation burns in Brazil: BASE-B Experiment. J. Geophy, Res., v. 97, p. 14601-19, 1992.

WARD, D.E. Smoke from wildland fires. In: HEALTH GUIDELINES FOR VEGETATION FIRE EVENTS, Lima, Peru, 1998. Geneva, WHO, 1999. p. 70-85. (Background papers). 
WARE, J.H.; THIDBODEAU, L.A.; SPEIZER, F.E.; COLOME, S.; FERRIS, B.G.Jr. Assessment of the health effects of atmospheric sulfur oxides and particulate matter evidence from observational studies. Environ. Health Perspect., v. 41, p. 255-76, 1981.

WARK, K.; WARNER, C.F.; DAVIS, W.T. Air pollution its origin and control. 3.ed. Menlo Park, Califórnia, Addison-Wesley. 1998. 573p

WESLEY, A.G.; LOENING, W.E. Assessment and 2-year follow-up of some factors associated with severity of respiratory infections in early childhood. S. Afr. Med. J. v. 64, p. 365-8, 1996.

WHITTEMORE, A.S.; KORN, E.L. Asthma and air pollution in the Los Angeles Area. Am. J. Public Health, v. 70, p. 687-96, 1980.

WHO Bi-Regional Workshop on Health Impacts of Haze-Related Air Pollution, Kuala Lumpur, Malaysia, 1998. Geneva, WHO, 1998, p.1-8 (Annex $\mathrm{H})$.

WHO. Health Guidelines for Vegetation Fire Events, ed. SCHWELA, D.H., GOLDAMMER, J.G., MORAWSKA, L.H., SIMPSON, O. Geneva, World Health Organization, 1999.

WHO Information, AIR POLLUTION, Fact Sheet, $\mathrm{n}^{\circ} 187.2000 \mathrm{a}$

WHO Information, VEGETATION FIRES, Fact Sheet, $n^{0} 254.2000 \mathrm{~b}$

YOKELSON, R.J.; SUSOTT, R.; WARD, D.E.; REARDON, J.; GRIFFITH, D.W.T. Emissions from smoldering combustion of biomass measured by open-path Fourier transform infrared spectroscopy. J. Geophy. Res. v. 102. p. 865-7, p.877, 1997.

ZANCUL, A. O efeito da queimada de cana de açúcar na qualidade de ar da região de Araraquara. São Carlos. 1998. 98 p. Dissertação (Mestrado)- Escola de Engenharia de São Carlos, Universidade de São Paulo. 
ZAR, J. H. Biostatistical analysis. 3. ed. New Jersey, Prentice Hall Inc., 1996.

ZMIROU, D.; BARUMANDZADEH, T.; BALDUCCI, F.; RITTER, P.; LAHAM, G.; GHILARDI, J.P. Short-term effects of air pollution on mortality in the city of Lyon, France, 1985 to 1990. J. Epidemiol. Community Health, v.50, p. S30-S35, 1996. Supplement 1. 